IZA DP No. 335

\title{
Disaggregate Matching Functions
}

\author{
René Fahr \\ Uwe Sunde \\ J uly 2001
}




\title{
Disaggregate Matching Functions
}

\author{
René Fahr \\ IZA, Bonn and University of Bonn
}

Uwe Sunde

$I Z A$, Bonn and University of Bonn

Discussion Paper No. 335

July 2001

\author{
IZA \\ P.O. Box 7240 \\ D-53072 Bonn \\ Germany \\ Tel.: +49-228-3894-0 \\ Fax: +49-228-3894-210 \\ Email: iza@iza.org
}

This paper can be downloaded without charge at:

http://papers.ssrn.com/abstract=xxxxxx

An index to IZA Discussion Papers is located at:

http://www.iza.org/publications/dps/

This Discussion Paper is issued within the framework of IZA's research area Mobility and Flexibility of Labor Markets. Any opinions expressed here are those of the author(s) and not those of the institute. Research disseminated by IZA may include views on policy, but the institute itself takes no institutional policy positions.

The Institute for the Study of Labor (IZA) in Bonn is a local and virtual international research center and a place of communication between science, politics and business. IZA is an independent, nonprofit limited liability company (Gesellschaft mit beschränkter Haftung) supported by the Deutsche Post AG. The center is associated with the University of Bonn and offers a stimulating research environment through its research networks, research support, and visitors and doctoral programs. IZA engages in (i) original and internationally competitive research in all fields of labor economics, (ii) development of policy concepts, and (iii) dissemination of research results and concepts to the interested public. The current research program deals with (1) mobility and flexibility of labor markets, (2) internationalization of labor markets and European integration, (3) the welfare state and labor markets, (4) labor markets in transition, (5) the future of work, (6) project evaluation and (7) general labor economics.

IZA Discussion Papers often represent preliminary work and are circulated to encourage discussion. Citation of such a paper should account for its provisional character. 
IZA Discussion Paper No. 335

July 2001

\section{ABSTRACT}

\section{Disaggregate Matching Functions*}

This paper deals with empirical matching functions. The paper is innovative in several ways. First, unlike in most of the existing literature, matching functions are estimated not only on aggregate, but also on disaggregate levels which is unusual due to the scarcity of appropriate data. Moreover, the unique data set used allows to distinguish inflows into jobs by sources. Results for different measures of flows found in the literature can therefore be replicated using a single data set. Labor markets can be disaggregated by occupations, rather than by industries or regions. Furthermore, disaggregation is possible for age and educational groups. The paper allows detailed insights into the pattern of frictions in labor markets, on mismatch and labor market tightness, and therefore provides valuable information necessary for the conduct of labor market policies.

JEL Codes: $\quad$ E24,J21,J41,J42,J62,J63

Keywords: Matching, empirical matching functions, vacancies, unemployment, occupational structure

René Fahr

IZA

P.O. Box 7240

D-53072 Bonn

Germany

Tel.: +492283894533

Fax: +492283894510

Email: fahr@iza.org

\footnotetext{
${ }^{*}$ We are indebted to Hielke Buddelmeyer for very helpful comments on an earlier draft. We thank Oliver Bruttel for assistance with the data. All errors are of course our own.
} 


\section{Introduction}

Labor market research has made extensive use of the concept of a matching function in recent years. In particular, the matching function appears as a shortcut to introduce frictions on the labor market in models investigating equilibrium unemployment. However, surprisingly enough, the bulk of research to date was theoretical. Moreover, the small existing literature investigating the empirical relevance of the concept rarely goes beyond the aggregate level. Consequently, the matching function is rarely used as an empirical concept to find out more about the structure of labor markets, in particular at less aggregate levels, and to compare the outcomes on different labor markets. This paper will argue that empirical matching functions can serve as a helpful instrument to get more information about the functioning of labor markets, in particular on disaggregate levels.

Most of the empirical literature on matching functions supports the relevance of the concept also in the data. However, little is known about sectoral or occupational differences with respect to matching and job creation and the closely related questions about labor market efficiency, relative supply shortages of specific skills and the like, issues which are particularly relevant when it comes to policy related questions. This paper is a first attempt to use the concept of a matching function to find out more about the structure of labor markets and thus to fill this gap.

The findings suggest that the relation between new hirings and stocks of job seekers and vacancies described by the matching function is indeed empirically relevant. The presumption of constant returns to scale of the aggregate matching function is not confirmed by the data. Not surprisingly, the findings for disaggregate matching functions differ substantially from aggregate results. Labor markets for different occupations seem to exhibit fundamentally different structures concerning the creation of new jobs. These differences are even more pronounced once labor markets are defined by different age or educational attainment instead of occupation. While some markets exhibit constant returns to scale, others are characterized by increasing or decreasing returns to scale. All in all, the results obtained from looking at disaggregate levels provide a very detailed picture of the functioning of labor markets. In particular with respect to policy advice, the approach followed in this paper is therefore superior to previous evaluations of empirical matching functions.

The following section briefly presents the theoretical concept of a matching function. Some related literature is surveyed and the empirical strategy followed in this paper is presented. Section 3 contains a detailed description of the data used in the empirical investigation and addresses interesting features of the data. The results of the empirical analysis are presented in the following reasonably self-contained sections: In section 4 we present results of estimations of aggregate matching functions. Section 5 studies data dis- 
aggregated by occupations. In section 6 , matching functions are estimated for different age cohorts, and in section 7 the dimension of disaggregation is education. Section 8 concludes.

\section{The Basics of Empirical Matching Functions}

As mentioned above, the bulk of research dealing with matching functions to date was theoretical. This section introduces the economic rationale behind the concept of a matching function and surveys some recent contributions attempting to evaluate the empirical content of the matching function, especially on disaggregate levels. Finally, the contribution of this paper is discussed in relation to the literature.

\subsection{Theoretical Background}

The matching function lies at the heart of the recent macroeconomic literature investigating equilibrium unemployment, labor market frictions, labor market efficiency and the like. It is essentially a short-cut to introduce frictions in the labor market and therefore to generate unemployment. In a nutshell, because of imperfect information, trading frictions etc., matches $m$ between workers looking for a job and firms looking for somebody to fill their vacancies do not arise instantaneously, but involve time consuming searching and finding of appropriate matches on both sides. ${ }^{1}$ The larger the pool of people actively searching for employment, $U$, and the more posted available job vacancies, $V$, firms try to fill, the more matches are generated. ${ }^{2}$ Essentially the matching function acts like a production function for new hires:

$$
m=m(U, V)
$$

with $\partial m / \partial U>0, \partial m / \partial V>0$, and $m(0, V)=m(U, 0)=0$. The precise formal representation is flexible and depends on the problem one wants to tackle, but the vast majority of theoretical contributions involving a matching function assumes decreasing marginal returns and constant returns to scale. ${ }^{3}$ The latter assumption is needed as to obtain a stationary unemployment rate (cf. Pissarides, 2000). This assumption is a hotly debated issue in

\footnotetext{
${ }^{1}$ See Petrongolo and Pissarides (2001) and the references therein for microfoundations of the matching function.

${ }^{2}$ There are also alternative specifications of matching functions other than the dependence of matchings on stocks of job-seekers and vacancies. Coles and Smith (1998) suggest a stock-flow approach according to which the stock on one side of the market is only matched to new inflows on the other side.

${ }^{3}$ Exceptions exist, see e.g. Armengol-Calvo and Zenou (2001) who provide a microfoundation for an aggregate matching function which does not exhibit constant returns to scale. See also Storer (1994), Warren (1996) and Yashiv (2000) for empirical studies allowing for flexible functional forms of the matching function.
} 
the empirical literature. For example, Blanchard and Diamond (1989) find constant or slightly increasing returns to scale using aggregate US data. Broersma and Van Ours (1999) argue that the results for the returns to scale depend heavily on the data for active job seekers and posted vacancies used and emphasize the importance of looking at comparable measures for flows and explanatory stocks. For example, they show theoretically as well as empirically that the results for returns to scale are upward biased if only flows from unemployment to employment rather than all flows to employment are considered while using the same explanatory variables. See Petrongolo and Pissarides (2001) for an extensive overview of the empirical results on the question of constant returns.

In what follows, we retain the Cobb-Douglas representation of the matching function that is predominant in the empirical literature. Denote $m_{t}$ as the total new hires at period $t$, or more precisely between $t-1$ and $t$, then

$$
m_{t}=m\left(U_{t}, V_{t}\right)=A U_{t}^{\alpha} V_{t}^{\beta}
$$

with $\alpha$ and $\beta$ being the elasticities of matchings with respect to job seekers and posted vacancies, respectively, and $A$ being a scale parameter capturing the overall efficiency of the matching process. Constant returns to scale implies $\alpha+\beta=1$.

Empirically, the matching function can be estimated exploiting cross sectional variation across $i$ entities of interest (like regions, industries or occupations) and time variation $t$. It is usually specified as a linear model containing a constant $C O N S$, a time trend $T$ and possibly other controls $Z$ :

$$
\ln m_{i t}=C O N S+\alpha \ln U_{i t}+\beta \ln V_{i t}+\gamma \ln Z_{i t}+\zeta T+\epsilon_{i t}
$$

Due to the Cobb-Douglas formulation, the time trend and other controls like occupation, age and education group dummies enter the matching process in the form of augmenting 'total matching productivity'. Due to the log-linear form of the estimation equation, positive coefficients can therefore be interpreted as an additional increase in the efficiency of the labor market with respect to forming new matches stemming from the respective variable. The opposite is true for negative coefficients. Back in the CobbDouglas context (without taking logs), this is equivalent to a factor of larger (or smaller) than one multiplying the total matching outcome due to the respective effect.

The relative sizes of the elasticities of the matching function with respect to the stock of unemployed and vacancies indicate the relative importance of labor supply and labor demand in the matching process. ${ }^{4}$ For example,

\footnotetext{
${ }^{4}$ Formally, they are equivalent to the matching shares of the respective inputs in the matching process, similar to the income shares in an ordinary Cobb- Couglas production function.
} 
in a labor market characterized by a small $\beta$ but a large $\alpha$, an additional vacancy creates nearly no new hirings, while an additional job seeker leads to a new match with a high probability. In other words, there prevails a relative supply shortage on this labor market. The interpretation of a relative demand shortage is analogous.

The data used in this study allow for estimations of matching functions for different measures of $m$ and hence to replicate previous studies. Therefore we adopt the following notation in what follows. All hirings within a given period and a given definition of a labor market are denoted by $m_{\text {all }}$. New matches consisting of formerly employed (without a spell of unemployment between two employment relationships) read $m_{E}$. Likewise, let new matches from unemployment be written as $m_{U}$, and matches from outside the labor force $m_{O L}$. Taken together, new hirings from unemployment and from outside the labor force are defined as hirings from non-employment: $m_{U}+m_{O L}=m_{X} \cdot{ }^{5}$ Finally, new matches from registered vacancies, as measured by successful placements by employment agencies, are denoted as $m_{R}$. Moreover, the data allow disaggregation of different measures of active job seekers.

\section{$2.2 \quad$ Related Literature}

In general, the empirical literature on aggregate matching functions, beginning with Pissarides $(1979,1986)$ and Blanchard and Diamond (1989), and recently Yashiv (2000) (see Petrongolo and Pissarides (2001) for an extensive survey), points at the empirical relevance of the concept and the strong implications of the labor market structure on the dynamic behavior of the economy.

Transferring the concept of a matching function to lower levels of aggregation comes at a price. Already on the aggregate level, there are a lot of problems with respect to the availability of appropriate data at appropriate frequencies. These problems aggravate once one starts looking at industry levels. The lack of disaggregate evidence lamented by Hall (1989) has to do with the difficulties of obtaining appropriate data on disaggregated levels. However, in principle the matching function can also sensibly be estimated exploiting cross sectional variation.

There have been several attempts to empirically analyze matching functions on disaggregate levels. Blanchard and Diamond (1990) use U.S. data to estimate an aggregate matching function and a matching function for the manufacturing sector, and they find differences in the parameters estimated, shorter vacancy duration than for the economy as a whole and higher returns to scale. Van Ours and Ridder (1995) test for job competition between different skill groups and conclude that there seems to be competition for new

\footnotetext{
${ }^{5}$ From this discussion it should also be clear that $m_{X}=m_{a l l}-m_{E}$.
} 
hires among high skilled while there is no evidence for job competition at lower levels of education. Recent contributions like Coles and Smith (1996), Anderson and Burgess (2000), and Burgess and Profit (2001) have found similar results by using cross sectional data on regional levels compared to those stemming from aggregate time series. However, the results vary for different concepts of pools of searchers, and exhibit some regional spillovers. The analysis of Broersma and Van Ours (1999) who use an industry panel on the 1-digit level for the Netherlands, suggests some variation in the structure of labor markets of different industries.

Recent contributions also addressed the problem of biases in the parameters of interest due to misspecified empirical matching functions. In particular, Broersma and Van Ours (1999) and Mumford and Smith (1999) emphasize the importance of estimating flows with the correct corresponding stocks, which are unobservable in the case of employed job seekers. Mumford and Smith, as well as Anderson and Burgess (2000) find evidence for significant job competition between employed and unemployed job seekers and crowding out effects.

For German data, aggregate matching functions have been estimated frequently, examples are Buttler and Cramer (1991), Entorf (1998) and references therein. Börsch-Supan (1991) estimates aggregate and disaggregate Beveridge curves for nine German regions using panel data of annual frequency for the years 1963-88. He is mostly interested in the dynamics and shifts in the Beveridge curve. Entorf (1998) uses panel data of yearly frequency for 40 occupational groups for the period 1971-1992. However, Entorf uses placements by the employment agency as dependent variable and concentrates on the dynamics without analyzing differences across occupations. His disaggregate findings differ from his findings on the aggregate level in the sense that the precision of the estimates is higher due to the use of more observations, thereby assigning vacancies a slightly higher importance in the matching process than unemployment (job seekers).

\subsection{The Empirical Strategy}

The primary aim of this paper is to deliver some comparable results on labor market structure across occupations, that is, on an even lower level of aggregation than previously investigated in the literature, and along a different dimension. The main interest lies in the time invariant fundamental modes of functioning of the labor markets and their structural differences. Therefore, losing quite a lot of the dynamics as the frequency of the data used is annual has to be taken into account. However, the data used are longitudinal, so that intertemporal and cross sectional variation can be ex-

ploited. The investigations undertaken below should therefore be seen in a long term context. The data used are exceptionally rich and do not suffer from many data problems usually encountered in empirical studies on 
the matching function. In our view, this compensates weaknesses in the dynamics of the data, and justifies their use.

In particular, the data allow for disaggregation along occupations, which is the relevant dimension for analyzing different labor markets, rather than disaggregating along industries. Separating labor markets by occupations allows looking at the relevant comparable measures for flows and stocks, comparing "apples with apples". Separating by industries or regions blurs the frictional differences of labor markets arising from differences in qualificatory demands or in search intensity, screening problems etc. underlying the idea of matching functions, because industries or regions typically employ all sorts of occupations (albeit with potentially varying weights). Moreover, evidence suggests that virtually all job seekers stay within their profession, to which they are more attached than to the industry they work in. But even the size of flows between industrial sectors is negligible, see Berman, Bound and Griliches (1994). Defining labor markets by occupations takes the structure of demand and supply and the differences in e.g. skill requirements and matching quality for certain jobs better into account. Moreover, switching industries within the same occupation might catch other effects than those interesting from the perspective of labor market structure as faced by policy makers deciding about training measures, immigration policies and the like.

In addition to the disaggregation by occupations, it is possible to identify flows for different age groups and for different education categories. Also these dimensions of disaggregation provide useful information for policy related questions.

With the data set described below it is also possible to replicate experiments like estimating different matching functions for different measures of job flows as was done by Broersma and Van Ours (1999). ${ }^{6}$ A novelty is that matching functions of the form of equation (3) with different measures of flows, like $m_{\text {all }}, m_{X}$ or $m_{U}$ as dependent variable can be estimated using the same data set.

We are aware of problems in the interpretation of the results resulting from job market competition between employed and unemployed and unobservable endogenous search behavior on both sides as was suggested by Anderson and Burgess (2000) and discussed in a companion paper (Fahr and Sunde, 2001). ${ }^{7}$ In this regard, we estimate several alternative specifications that try to regress flows of new hires on the correct corresponding stocks as explanatory variables. Therefore, in addition to the standard specification with all hirings as dependent variable, we present results estimations for hirings from non-employment and from unemployment to employment using unemployed job seekers as an explanatory variable, which can all be

\footnotetext{
${ }^{6}$ Unfortunately, the data do not allow to investigate alternative matching approaches like the stock-flow approach suggested by Coles and Smith (1998).

${ }^{7}$ See Pissarides $(1994,2000)$ for a theoretical model of on-the-job-search and endogenously determined search intensity.
} 
identified thanks to the richness of the data. Except for making the implicit assumptions usually made in the empirical literature like assuming that all offers are accepted, that there is no ranking of applicants, as in Blanchard and Diamond (1994), and that non-employed job seekers search all and with the same intensity over time, no further assumptions e.g. on the search behavior of employed etc. have to be made to be able to interpret the results.

Another potential flaw of the empirical strategy is danger of spurious regression results if the data are non-stationary. In this case, conventional critical values for $t$-statistics lead to misinterpretation since appropriate critical values would have to exceed the conventional ones. Standard unit root tests to detect non-stationarities have low power in short time series. Developing unit root tests for panel data, in particular of short time dimension, is currently an area of intense econometric research. ${ }^{8}$ However, Entorf (1998), who uses similar data to ours, discusses these issues in detail and concludes that unit roots in the in the data on vacancies, unemployment and placements are unlikely. ${ }^{9}$ Therefore, strictly speaking, the results below only hold under the assumption of stationarity of the data used which is not tested formally, but which is taken as granted given the results obtained by Entorf (1998) and others. ${ }^{10}$

In every stage of the empirical analysis, we follow an identical plan: First, we present descriptive results and interesting features of the data described in the next section. In particular, because of the richness of the data it is possible to distinguish flows to employment, that is new matches, by their sources and for different dimensions of disaggregation. Then, we estimate different specifications of the benchmark matching equation (3). For the reasons just mentioned, we present results for regressing various measures of matches, in particular $m_{a l l}, m_{X}$ and $m_{U}$, on stocks of unemployed and vacancies.

\section{Data}

The data used for the analysis below are yearly data on unemployment, vacancies, employment levels and flows from registered vacancies to employment for Western Germany. The data are from official labor statistics and disaggregated at the occupational level. Occupations are defined by notifications by the current employer about the current activity or job and are

\footnotetext{
${ }^{8}$ See Maddala and $\mathrm{Wu}, 1999$, and Phillips and Moon, 2000, for recent overviews.

${ }^{9}$ Entorf uses data from the same sources and for an almost identical period (19711992), but less detailed than those used in this study. For instance, he distinguishes only 40 occupational groups, while we have data on 83 occupations. Moreover, while he uses data on placements as measure for hires, we use the arguably more appropriate social security notifications to identify matches.

${ }^{10}$ Most of the empirical literature on matching functions, in particular using disaggregate data, attaches little importance to the problem of spurious regression.
} 
part of an individual's social security record. ${ }^{11}$

Moreover, contrary to virtually all data sets used in the literature (e.g. Anderson and Burgess, 2000) also data on the pools of job seekers and vacancies are disaggregated. ${ }^{12}$ In contrast to the help-wanted index frequently used in U.S. studies, the vacancy measure provides detailed information about all vacancies registered at local employment offices. The data where originally disaggregated by 83 occupational groups. For all estimations, the occupational group collecting all unspecified occupations, trainees and apprentices (group 98) is dropped, which leaves us with 82 occupational groups throughout the empirical analysis. ${ }^{13}$ In the definition of relevant aggregation levels of labor markets, there is a trade-off between disaggregating as much as possible on the one hand and representing labor markets as homogenous entities on the other hand. ${ }^{14}$ Therefore, observations were clustered in nine broad occupational groups. ${ }^{15}$ The groups were purely constructed on economic grounds. In particular, the criterion for the grouping was the proximity and relatedness of occupations with respect to skill requirements and the activities usually performed. The hirings are measured on the individual level and stem from an anonymized representative 1\% sample of German social security records. The data are available for the years 19751995. The database is supplemented by data on unemployment benefits recipients and by establishment information (see Bender et al. (2000) for details.) Because there is some measurement error in the data before 1980 and to keep the data comparable to the aggregate data from labor statistics, the observations from 1980 to 1995 are retained for the empirical analysis.

The individual data include a firm identifier and information on the employment status. All in all, the data allow to identify hirings from one year to another for each occupation by source of hiring. Specifically, hirings from out of the labor force, from unemployment, and from employment can be distinguished. ${ }^{16}$

There is, however, a shortcoming in the data regarding the distinction of hirings from unemployment and hirings from out of the labor force. Due to measurement error in the data, our measure of hirings from out of the

\footnotetext{
${ }^{11}$ For unemployed individuals or individuals out of the labor force, occupation is defined by the notification of their last employer about their last job.

${ }^{12}$ This is true for the main focus of disaggregation in this paper, the disaggregation by occupation

${ }^{13}$ On average over the entire observation period, the members of group 98 make up for about 0.17 percent of total employment. The effect of dropping this group is therefore negligible.

${ }^{14}$ In particular, it is desirable to design occupational groups so as to represent labor markets in order to capture miscodings and to treat changes between germane occupations as within-group events.

${ }^{15}$ The data appendix provides a detailed description of the data used in the analysis including a list of occupational groups.

${ }^{16}$ However, due to use of social security data, holders of jobs which are exempt from social security payments are not recorded as employed.
} 
labor force in fact measures hirings from out of the labor force as well as hirings from unemployment (see data appendix for details). On the other hand, our measure of hirings from unemployment underestimates the true number of hirings from unemployment. Nevertheless we could clearly measure total hirings, flows from employment to employment and hirings from non-employment. Despite the measurement problems with our measure of hirings from unemployment, we present results for $m_{U}$ along results for flows from non-employment $m_{X}$, because our measure of $m_{U}$ serves as a better proxy for the true number of hirings from unemployment than comparable data used in the literature. The precise identification from the sources of flows to employment is important because, as already found by Broersma and van Ours (1999) and Mumford and Smith (1999), estimates of matching functions vary considerably with the respective flows considered. However, the data are even richer than theirs in that they allow disaggregation to lower levels and along several dimensions. The central focus of disaggregation is on the occupational level. The data also allow to disaggregate flows to employment in total and by sources along other relevant dimensions like age and education. The richness of the data thereby allow to investigate all sources of flows to employment by three age groups and three educational levels, which is another innovation in the context of empirical matching. ${ }^{17}$

One problem of the data is that unemployment and vacancy rates are reported for certain reference dates only while the flows to employment are calculated for a given period, in the data set one year. From a conceptual point of view, the data for the relevant stocks of job seekers and vacancies should therefore represent all units seeking during that period, that is, ideally one would like to have the number of all individuals that have been unemployed for some time during the respective period rather than only at the reference date. In order to capture the relevant stocks better in this respect, some attempts have been made to create data that come closer to the theoretically desirable measures. ${ }^{18}$ Later in the text we will refer to estimation results obtained with these adjusted stocks as explanatory variables. These results serve as robustness check for the main results presented in what follows.

\section{Aggregate Matching}

This section summarizes the results from estimations of different specifications of the matching function as specified in equation (3) using data aggregated up from 82 occupational groups for the period 1980 to 1995. These

\footnotetext{
${ }^{17}$ Information on the education attainment is reported by the employer and might therefore contain some measurement error. This should be taken into account when interpreting the results.

${ }^{18}$ Details on how these adjusted stocks are constructed are described in the Data Appendix.
} 
results are of particular interest since the literature on empirical matching functions is based almost exclusively on aggregate time series data at much higher frequencies. The next subsection discusses the benchmark results and different time structures. Particular attention is payed to the question whether the aggregate matching function exhibits constant returns to scale. Finally, we present estimates of matching function for different measures of flows.

\subsection{General Results}

Descriptive statistics of the data are listed in Table 4-1. It is striking that the vacancy rate is so much smaller than the unemployment rate. This has to do with the fact that both measures are collected for reference dates, but that the average duration of a vacancy is a lot shorter than that of an unemployment spell. It is interesting to note that more than two thirds of all new hirings affect individuals who are not employed. ${ }^{19}$ The numbers obtained for hirings from unemployment and out of the labor force by disaggregating further reveal surprisingly high flows from out of the labor force and surprisingly low flows from unemployment. However this has to do with the coding of the data mentioned before, so these numbers have to be taken with a big grain of salt. Flows from non-employment seem to be a lot more reliable and the analysis below will thus concentrate on those. Flows from registered vacancies make almost 60 percent of total flows and are measured as successful placements by the employment agencies. The main problem with these flows is that according to official statistics up to 20 percent of successful placements result in employment relations that end within less than 8 days. Therefore, also results obtained using this flow have to be interpreted with care.

\section{[ Insert TABle 4-1 ABout here. ]}

Table 4-2 presents results from estimating several specifications of a standard Cobb-Douglas matching function of the form of equation (3). The baseline specification (1) contains a linear time trend. Specification (2) additionally includes dummies for broad occupational groups. In both cases, the hypothesis of constant returns to scale can be rejected at the $1 \%$-level. The stock of unemployed job seekers has a slightly higher weight in the creation of total new matches than the stock of registered vacancies. The linear time trend has a significant negative coefficient indicating an increase in the frictions on the labor market over time. This pattern is virtually

\footnotetext{
${ }^{19}$ The numbers are roughly in line with those mentioned in the literature: Blanchard and Diamond (1989) conclude that in their U.S. data, $m_{E}$ are about 15 percent of total matches while $m_{U}$ and $m_{O L}$ make up for 45 and 40 percent, respectively. According to Burda and Wyplosz (1994), German data reveal 16, 42 and 42 percent for $m_{E}, m_{U}$ and $m_{O L}$.
} 
unchanged qualitatively as well as quantitatively once time dummies are introduced instead of a linear time trend (specification 3), and when dummies for 9 broad occupational groups are added (specification 4). However, while the coefficients for all time dummies are consistently negative, they become highly significant only after 1985, and their absolute value increases over time. This indicates a deterioration in the efficiency of the functioning of the labor market over time, equivalent to an outward shift of the Beveridge Curve. The finding of negative time effects is consistent with what is found in the literature, typically starting with the early 1960s (see Pissarides and Petrongolo, 2001, for a survey.) Controlling for GDP (model 5), GDP growth (model 6), and both (model 7 ) leaves the results virtually unchanged while the coefficients for the controls are not significant. ${ }^{20,21}$

\section{[ Insert TABle 4-2 ABout HeRE. ]}

The results obtained using panel data fit in the broad picture obtained by numerous studies of empirical matching functions obtained with aggregate time series data (see Broersma and Van Ours (1999) for an overview.) One striking difference to most previous results is that the matching elasticity with respect to unemployment is consistently higher than that for vacancies. One has to bear in mind, however, that the matching function estimated might be misspecified in the sense that the stocks used as explanatory variables might not be the relevant measures since for instance the pool of employed job seekers is neglected completely. We take a closer look at this problem below and in Table 4-3. These results are indeed particularly interesting in the light of the result of Broersma and Van Ours (1999). They argue that ignoring relevant parts of the explanatory stock of job seekers leads to an underestimation of the true value of the matching elasticity with respect to the number of job seekers. This point will be discussed in more detail below in section 4.3.

The estimation results obtained so far could potentially be biased due to time aggregation problems, because flows could affect contemporaneous stocks used as explanatory variables. The usual remedy for this problem in the literature is to use lagged values of the explanatory variables, that is the stock of unemployed and the stock of vacancies, as instruments for the contemporaneous data (see Petrongolo and Pissarides, 2001). In order to

\footnotetext{
${ }^{20}$ Note that including macro variables in a regression like time trends, GDP or GDP growth leads to downwardly biased standard errors, see Moulton (1990). A correction of the standard errors would therefore render the coefficient estimates for time trend, GDP and GDP growth less significant. We refrain from a correction of the standard errors, since the results for time trends have very low standard errors and are virtually identical to those for time dummies, and because the coefficients for GDP and GDP growth are insignificant anyway.

${ }^{21}$ In specifications without time trend, coefficients for GDP and GDP growth, respectively, are negative and highly significant.
} 
check the robustness of the results presented, we perform the same analyzes as in Table 4-2 using the stocks of job seekers and vacancies lagged by one and lagged by two periods. The results of these estimations are contained in Tables A4-2-1 and A4-2-2 in the appendix. Taking lagged stocks as instruments leaves the results qualitatively unchanged and even quantitatively the differences are mostly negligible. ${ }^{22}$

Another potential problem has been already mentioned before in the data section. Explanatory variables are reported only for reference dates and therefore do not represent the correct measures for stocks of unemployed and vacancies relevant for the estimation of matching functions. In order to overcome this problem, the reference data have been adjusted using aggregate data on total yearly inflows into unemployment and registered vacancies. Estimations of the same specifications of the matching functions as in Table 4-2 using these adjusted stocks as explanatory variables deliver almost identical results. ${ }^{23}$ We take this as an indication that the results obtained with the non-adjusted data are reasonably robust and accurate.

Due to the similarity of the results obtained by including time trends or time dummies, in what follows, matching functions will be estimated including a time trend.

\subsection{Returns to Scale}

The central question about empirical matching functions addressed in the literature is whether the matching function indeed exhibits constant returns to scale. Although this is not the main focus of the paper, this section comments briefly on the results obtained for the data set under investigation.

The results for different specifications of aggregate matching functions presented in Table 4-2 indicate that the sum of unemployment and vacancy elasticities of new matches sum up to less than one which implies decreasing instead of constant returns to scale. The results of F-tests for the null that the sum of the coefficients equals one, that is constant returns, clearly reject the constant returns hypothesis at any reasonable significance level.

In order check the robustness of this result we follow Warren (1996) and Yashiv (2000), and estimate a flexible specification of the matching function instead of the arguably restrictive Cobb-Douglas. In particular, a transcendental logarithmic model of the matching technology is applied. Compared to other flexible forms like a generalized Leontief or a linearquadratic specification, the translog gives less biased estimates of the degree of returns to scale of a known technology (Guilkey et al., 1983). The basic translog specification is

\footnotetext{
${ }^{22}$ Note that this is a frequently reported finding in the literature, see e.g. Warren (1996).

${ }^{23}$ The estimation results for adjusted explanatory variables are contained Table AA 4-2 in the appendix.
} 


$$
\begin{aligned}
\ln m_{i t} & =a_{0}+a_{1} \ln U_{i t}+a_{2} \ln V_{i t}+\frac{1}{2} a_{11}\left(\ln U_{i t}\right)^{2}+\frac{1}{2} a_{22}\left(\ln V_{i t}\right)^{2} \\
& +a_{12}\left(\ln U_{i t} \ln V_{i t}\right)+a_{3} T+\mu_{i t}
\end{aligned}
$$

where $U$ is the stock of unemployed, $V$ is the stock of vacancies and $T$ is a linear time trend. In order to determine the returns to scale one has to add up the respective partial elasticities of new matches with respect to the stock of unemployed $\epsilon_{U}$ and the stock of vacancies $\epsilon_{U}{ }^{24}$

The estimation results for total hirings per period and occupation, $m_{\text {all }}$, are as follows: ${ }^{25}$

$$
\begin{aligned}
& \ln m_{\text {all }}=\underset{(0.534)}{\substack{9.702 \\
(0.148)}}-\underset{(0.104)}{0.268 \ln U}+\underset{2}{0.197 \ln V}+\frac{1}{2} \underset{(0.027)}{0.087(\ln U)^{2}} \\
& +\frac{1}{2} \begin{array}{lrr}
0.055(\ln V)^{2} & -0.014(\ln U \ln V) & - \\
(0.021) & 0.034 T \\
(0.021) & (0.003)
\end{array} \\
& R^{2}=0.871, \quad N=1311,
\end{aligned}
$$

The resulting overall matching elasticity with respect to unemployment is $\epsilon_{U}=0.442$, and for vacancies $\epsilon_{V}=0.443$, which implies decreasing returns to scale of $0.885 .{ }^{26}$ Hence, the use of a flexible form also indicates decreasing returns to scale for the aggregate matching function rather than constant returns to scale. ${ }^{27}$ The estimation results for flows from non-employment are:

$$
\begin{aligned}
& \ln m_{X}=\begin{array}{l}
9.429 \\
(0.695)
\end{array} \quad \begin{array}{l}
0.187 \ln U \\
(0.180)
\end{array}+\underset{(0.117)}{0.151 \ln V}+\frac{1}{2} \underset{(0.027)}{0.057(\ln U)^{2}} \\
& +\frac{1}{2} \begin{array}{l}
0.020(\ln V)^{2} \\
(0.014)
\end{array}+\begin{array}{lr}
0.017(\ln U \ln V) & -0.037 T \\
(0.017) & (0.003)
\end{array} \\
& R^{2}=0.850, \quad N=1310
\end{aligned}
$$

The respective elasticities of new hires from non-employment are $\epsilon_{U}=0.456$ and $\epsilon_{V}=0.445$, which yields returns to scale of 0.901 . Likewise, for new

\footnotetext{
${ }^{24}$ The unemployment elasticity is $\epsilon_{U}=a_{1}+a_{11} \overline{\ln U}+a_{12} \overline{\ln V}$, the vacancy elasticity is $\epsilon_{V}=a_{2}+a_{22} \overline{\ln V}+a_{12} \overline{\ln U}$. The respective sample means for evaluating the quadratic and interaction terms are $\overline{\ln U}=9.253$ and $\overline{\ln V}=6.820$.

${ }^{25}$ Robust standard errors are in parentheses.

${ }^{26}$ Note that a structural interpretation of the coefficients and the elasticities is problematic for translog models due to the local character of the results, see Guilkey et al., 1983.

${ }^{27} \mathrm{An}$ F-test of the null that the parameters jointly fulfill the requirements for constant returns to scale exhibits an F-statistics of $F(3,1304)=54.79$. This implies that the null can be rejected at any reasonable significance level.
} 
hires from unemployment we get:

$$
\begin{aligned}
& \ln m_{U}=\underset{(0.974)}{8.076}-\underset{(0.297)}{0.411 \ln U}+\underset{(0.196)}{0.346 \ln V}+\frac{1}{2} \underset{(0.048)}{0.073(\ln U)^{2}} \\
& -\frac{1}{2} \begin{array}{lrr}
0.053(\ln V)^{2} \\
(0.021)
\end{array}+\begin{array}{lr}
0.039(\ln U \ln V) & -0.030 T \\
(0.028) & (0.005)
\end{array} \\
& R^{2}=0.719, \quad N=1298
\end{aligned}
$$

Straightforward calculations give $\epsilon_{U}=0.530, \epsilon_{V}=0.345$, and returns to scale of $0.875 .{ }^{28}$ To summarize, results for specifications with different measures of matches, in particular all hirings, hirings from non-employment and from unemployment, consistently lead to similarly strong rejections of the hypothesis of constant returns to scale in favor of decreasing returns.

In order to allow comparisons to the existing literature, the models (1) to (7) presented in the previous section and models (8) to (13) to be presented next are estimated with restrictions on the parameters so as to impose constant returns to scale. The results are presented in Tables A4-2-3 and A4-3-3 in the appendix.

\subsection{Matching Functions by Sources of Flows}

The data set allows to disentangle new matches by the source of either the successful job seekers or the type of successful vacancies. That is, successful matches of formerly unemployed can be distinguished from successful matches of individuals switching from another job to their new match, etc. Table 4-3 presents the results for matching functions defined by the sources of flows. The models presented replicate all flow specifications used in the literature as presented by Broersma and Van Ours (1999) using one single data set and therefore allow for direct comparisons of the different results.

\section{[ Insert TABle 4-3 ABout here. ]}

The first model (model (8)) repeats the results for taking total hirings per occupation and period as was already displayed in Table 4-2. Across all specifications, the time effect is negative and, with exception of model 13, significant, which is a common result in the literature (see above).

Looking at hires from non-employment, which is the dependent variable in model (9) we find very similar coefficients for the matching elasticities. Since the literature comes to mixed conclusions about the relative size of the matching elasticities we take our outcomes as a consequence of using an identical data set also for the benchmark model. This might also be an

\footnotetext{
${ }^{28}$ F-statistics for constant returns to scale are for flows from non-employment $F(3,1303)=40.19$ and for flows from unemployment $F(3,1291)=22.86$, respectively.
} 
indication for the robustness of our results. Due to the fact that flows from non-employment are very reliable, the results indicate that the biases due to incompatibility of flows and stocks used (Broersma and Van Ours, 1999) or endogenous job competition (Mumford and Smith, 1999, Anderson and Burgess, 2000) are rather moderate. This point is taken up again shortly.

The dependent variable in model (10) is hires from employment. Although conceptually the model is misspecified at least with respect to the pool of job seekers, which is the stock of unemployed, the results are very similar to the ones obtained for the benchmark model. In contrast to the results obtained by others, the coefficient for vacancies is lower than the coefficient for the stock of unemployed.

Model (11) regresses matches from unemployment on the stock of unemployed and the stock of vacancies. The elasticity of matches with respect to the stock of job seekers is higher, the elasticity with respect to vacancies lower than in the benchmark model. The intuition behind this result is that total flows into a job capture also jobs filled with employed job seekers. Therefore, an identical increase in the stock of unemployed job seekers leads to a smaller increment in total matches than if only unemployment outflows into a new job are looked at, simply because there is crowding out by employed job seekers. A similar argument can be given to explain the smaller elasticity of vacancies for outflows from unemployment: Since the pool of potential applicants actually is higher for total flows to jobs than for unemployment outflows, posting one more vacancy has a higher effect on total hirings than on unemployment outflows. Qualitatively the same results - a higher matching elasticity with respect to the stock of unemployed than with respect to vacancies - is consistently found in the literature, albeit with somewhat higher coefficients for unemployment than obtained in the present study. However, as mentioned before, the results for flows from unemployment as well as for flows from out of the labor force to be inspected below have to be interpreted with care as the data contain a potentially large number of miscodings. Interestingly, the observation by Broersma and Van Ours (1999) that estimates for returns to scale are upward biased when regressing $m_{U}$ instead of $m_{\text {all }}$ is not supported in our data.

If new matches of individuals from outside the labor force are taken as the object of study (model 12), again the estimated elasticities are in line with the previous findings. However, the coefficient for vacancies is slightly higher than in the other models and also higher than the coefficient for the stock of unemployed, indicating that the availability of job opportunities might affect the participation decision positively, as one would expect.

Finally, the data set allows to identify new hires resulting from registered vacancies, which is taken as the relevant flow in model (13). The results for this specification show the strongest discrepancy from the main pattern of results obtained before. The coefficient for unemployment is higher, the coefficient for vacancies lower than in all other cases. A short discussion of 
these findings is in order.

The main point of Broersma and Van Ours (1999) is to stress the importance of specifying the matching function such that the measure of flows (new matches) corresponds to the measures of stocks of job seekers and vacant positions. From a conceptual point of view, the models presented in this section are problematic in this respect since, strictly speaking, one would have to estimate e.g. model (10) with employed job seekers instead of the stock of unemployed. However, the stock of employed actively searching for a new job is not observable. Therefore, the stock of unemployed might serve as an instrument for the stock of employed job seekers. But in this case, problems regarding the composition of the pool of job seekers and crowding out effects, as investigated by Anderson and Burgess (2000) are neglected. In turn, the estimated parameters might be biased due to the misspecification. To avoid these problems, and in order to be able to interpret the results for disaggregate matching functions in the remainder of the paper in the context of the existing literature, in what follows we present results for models of type (8), (9) and (11). We pay particular attention to models of type (9). In this specification, the outflows from non-employment into work are estimated using the stock of unemployed job seekers and the stock of registered vacancies. This implicitly assumes that the stock of unemployed represents the relevant stock of non-employed job seekers sufficiently well and that non-employed, that is unemployed or individuals (re-)entering the labor market, predominantly apply for registered instead of non-registered vacancies. An alternative would be to use the same explanatory variables for regressing flows from registered vacancies (model 13), assuming that these are (almost) exclusively filled with unemployed. However, the results in Table 4-3 reveal differences in the estimated matching elasticities with respect to the pool of unemployed. The significantly higher coefficient in the model for flows from registered vacancies could indeed be an indication for endogenous search behavior of employed individuals which is contained in this specification but not in the other one for outflows from non-employment: An additional job seeker has a higher impact in this model because implicitly also some employed job seekers have the chance to lead to a successful match. Therefore, the emphasis on models of type (9) in the analysis of disaggregated matching functions is warranted.

In order to check for the robustness of the results with respect to time aggregation problems, all specifications of Table 4-3 are replicated with instrumenting the stocks of job seekers and vacancies lagged by one and lagged by two periods (see Petrongolo and Pissarides, 2001). The results of these estimations are contained in Tables A4-3-1 and A4-3-2 in the appendix. Taking lagged stocks as instruments delivers results that are qualitatively as well as quantitatively almost identical.

For matter of comparison, we also estimate the same specifications as in Table 4-3 while imposing constant returns to scale, shown in Table A4-3- 
3. For completeness, all models contained in Table 4-3 are estimated in a two-way fixed effects panel specification. The results are contained in Table A4-3-4 in the appendix. The results change somewhat. In particular, the differences between the alternative models become more pronounced. The most striking difference is in the model estimated with flows from employment as dependent variable (model 10'), where the elasticity with respect to the stock of unemployed goes up from 46 percent to 57.5 percent in the panel specification, while the vacancy elasticity goes down from 41.7 percent to 27.1 percent with comparable explanatory powers of the models. Constant returns to scale are unanimously rejected also in all panel models.

As a further robustness check, models (8) to (13) are also estimated using the adjusted stocks in order to alleviate the reference date problem. ${ }^{29}$ The results obtained from these experiments differ somewhat from the results obtained using unadjusted stocks. In particular, while for all hirings and for hirings from out of the labor force (models 8 and 12) as dependent variables the outcomes are virtually identical, unemployment elasticities are somewhat lower and vacancy elasticities somewhat higher for flows from nonemployment and unemployment (models 9 and 11) when adjusted stocks are used. The opposite is true for new matches from employment (model 10). However the differences are quite small, the largest difference between comparable elasticities being a mere 8 percent, so that one can be confident with the estimates obtained with unadjusted data. Substantial differences are only found for flows from registered vacancies (model 13), where the unemployment elasticity is almost 30 percent and the vacancy elasticity almost 12 percent higher once adjusted stocks are used as explanatory variables. As with unadjusted stocks, constant returns to scale are rejected for all specifications. These findings confirm our confidence that the estimates obtained with unadjusted explanatory variables are robust and reasonably accurate.

\section{Matching by Occupational Groups}

While the bulk of the existing literature on empirical matching functions focuses on aggregate data and concentrates on the dynamic aspects of job creation (and destruction), little is known about cross-sectional patterns of matching. Recently, a few studies considered the regional dimension of labor markets and analyzed regional differences in matching. Among others, Coles and Smith (1996) look at differences between labor markets in England and Wales, Burda and Profit (1996) estimate matching functions with district level panel data for the Czech republic, and Burgess and Profit (2001) study 8 travel-to-work areas in Britain. Broersma and Van Ours (1999) use Dutch data disaggregated by industries, while Anderson and Burgess (2000)

\footnotetext{
${ }^{29}$ Estimation results are contained in Table AA 4-3 in the appendix.
} 
interact spatial and cross-industry variation for U.S. data. ${ }^{30}$

While all studies find effects of spatial and/or industrial heterogeneity on the matching outcomes, no study has used data disaggregated by occupations. ${ }^{31}$ However, occupation might well be considered to define the relevant labor markets as faced by participants, that is job seekers and vacancy posting firms. Occupation captures skill requirements and characteristics, similarities of tasks etc.and therefore defines the potential labor market on which the participants search for a new match better than for example industry. ${ }^{32}$ Moreover, occupations are objectively defined in public data. This is even more true for the German education system in which there are education and training certificates for nearly every occupation. Occupations are defined by the notification of the employer (or the last employer if the individual is currently not employed) in the individual's social security records. These notifications are not only reasonably precise but also keep track of the working history of an individual. In contrast to that, the definition of regional labor markets and travel-to-work areas arguably contains a bit more arbitrariness. Therefore, exploring labor market structure and matching functions for different occupations is an important issue which has been neglected so far. As described in the data section, we group occupations into nine broad occupational groups. In order for matching functions to be estimated in a meaningful way, stocks and flows should correspond to the same labor market. For this to be true, the flows between occupations should not be too high in order for the distinction of labor markets by occupations to be relevant. In the data at hand, on average less than two percent of the labor force change broad occupations in a given year. On average, less than a third of all new hirings involves a change of broad occupation. The bulk of these flows between occupations is concentrated among a few groups and the overall picture is that even fewer matches involve between group changes. ${ }^{33}$ Therefore we emphasize occupations as defining labor markets as a feature of relevance which has been almost completely neglected so far. Figure A1 in the appendix illustrates the evolution of the sizes of the broad occupational groups over the entire observation period 1980 - 1995.

\subsection{General Results by Occupation}

Table 5-1 shows the results for estimations of the standard matching function of specification (3) when occupation dummies for nine broad occupational

\footnotetext{
${ }^{30}$ See Petrongolo and Pissarides (2001) for a survey of the - small - literature.

${ }^{31}$ Entorf (1998) uses information on occupations, but does not analyze the effects of occupations. He rather concentrates on the dynamic variation of matching functions and Beveridge Curves.

${ }^{32}$ Of course there might be correlations between certain industries and certain occupations.

${ }^{33}$ For example, about 20 percent of the flows between broad occupational groups are flows between manufacturing occupations and crafts (groups 2 and 3).
} 
groups are added. As already discussed before, the dummy for a given occupational group acts as augmenting the total factor productivity of the matching function. Positive coefficients indicate an increase in the overall efficiency for the respective group, and negative coefficients a decrease. In order to obtain results that do not rely on which reference group is chosen, we transform the dummy coefficients following the approach suggested by Haisken-DeNew and Schmidt (1997). After regressing logged matches on a set of explanatory variables and dummies (excluding a reference group), the coefficients obtained for the dummies are renormalized as weighted deviations from the weighted mean of all groups. ${ }^{34}$ As a consequence, also the variance-covariance matrix and the standard errors of the coefficients are adjusted.

\section{[ Insert TABle 5-1 ABout here. ]}

In model (14), the dependent variable is all hirings, in model (15) only matches from non-employment are considered as dependent variable. The coefficients for the stocks of job seekers and vacancies for all hirings and hirings from non-employment are virtually identical to those already obtained before in Tables 4-2 and 4-3. The null-hypothesis of constant returns to scale can be rejected in all cases at any level of significance. The results for the dummies are striking. In models (14) and (15), except for group 9 (low skilled occupations), the dummy coefficients are qualitatively identical. Those which are highly significant are also quantitatively very similar for both concepts of hirings used, with the exception of the primary sector. The negative coefficient means that new matches are less likely for members of this group, than on average over all occupations. However, this disadvantage is a lot smaller for matches from non-employment than for all hirings. The groups for which the labor market seems to be particularly dynamic in the sense that compared to the average flows over all groups more matches occur ceteris paribus, are high skilled and health occupations (groups 6 and 8). The opposite is true for technical occupations (group 4) which create significantly fewer matches ceteris paribus. One reason for this might be that the market for these individuals is less dynamic, for example because the positions they usually fill have very particular skill requirements, high capital intensities or bear high responsibility. Another interpretation is that these jobs offer generous compensation packages and that thus turnover is low. Crafts (group 3) represent a relatively efficient labor market with more matches than the average. This could be explained by the fact that the German apprenticeship system provides a homogeneously high level of human capital which is highly transferable, so more employment relations can

\footnotetext{
${ }^{34}$ The group sizes which are necessary as weights for the deviations as well as for the calculation of the mean are given by the number of occupations contained in the respective broad occupational group, because occupations are the unit of observation.
} 
be created as desired skills are easily observed. For completeness, model (16) is added where the dependent variable is matches from unemployment. Constant returns can be rejected as in the two specifications described before. The other results are qualitatively the same with the exception of the occupation dummies for manufacturing (group 2) and health (group 8) occupations. The former exhibits a significant positive, the latter a significant negative effect, exactly opposite to what is found when regressing all hirings or hirings from non-employment.

\subsection{Returns to Scale}

As seen before, if the matching function is imposed to have identical elasticities for stocks of job seekers and vacancies, as was done in the estimations with occupation dummies included, constant returns to scale are rejected in favor of decreasing returns to scale. In this subsection, matching functions of the same form (eq. 3) are estimated separately for each broad occupation group. The results are presented in Tables 5-2 and 5-3.

Model (17) takes all hires for the respective occupation group as dependent variable, while the dependent variable in model (18) is hirings from non-employment for the respective occupation group. ${ }^{35}$ A first inspection shows that the results are very similar for both concepts of flows used. When total matches are looked at, the hypothesis of constant returns to scale can be rejected at any reasonable significance level.

\section{[ Insert TABles 5-2 AND 5-3 ABOUt HeRE.]}

As before, one model takes all hirings as dependent variable (model 17), while another looks at hirings from non-employment only. With respect to the question of returns to scale, the results are almost identical. Constant returns to scale cannot be rejected for occupations in the primary sector (group 1), for service occupations (group 5) and for health occupations (group 8), and this is consistent regardless of which measure for matches is used as dependent variable. The only exception is low skilled (group 9), for which constant returns can be accepted for total hirings, but has to be rejected once hirings from non-employment are regressed. Interestingly, crafts and technical occupations (groups 3 and 4) exhibit increasing returns to scale. The overall picture is therefore very mixed. The degree of homogeneity of the matching function very much depends on the occupation under consideration. Moreover, the argument of increasing returns on the micro level and constant returns on the macro level as suggested in the literature (see Diamond (1982) and Coles and Smith (1998) for a microfoundation based on

\footnotetext{
${ }^{35}$ For matters of completeness and comparison, Table 5-3 contains estimates for all hirings (model 17) and hirings from unemployment (model 19).
} 
overlap of adjacent labor markets) seems to be supported only to a limited extent by our data.

Furthermore, also with respect to the sizes of the coefficients for stocks of unemployed and vacancies, the results reveal a pronounced heterogeneity across groups. The overall picture is the same regardless of what measure for matches is taken as the dependent variable. Roughly speaking, there are three categories of occupations. For groups 1, 7 and 9 (manufacturing, social and low skilled occupations), new matches are more elastic with respect to the stock of vacancies than unemployment. The opposite is true for all other groups, and particularly strong in technical occupations. The only exception is manufacturing (group 2) where labor supply and demand have about equal weights in creating new hires. Also the time trends exhibit interesting differences across groups. ${ }^{36}$ The coefficient for the time trend is negative and significant at the aggregate as well as for most groups when taken separately with a value of about three to five percent. The negative value is largest for primary sector occupations (group 1) with around 12 percent. On the other hand, the coefficient for the time trend is not significantly different from zero for technical, white collar, social and low skilled occupations (groups 4, 6, 7 and 9). This indicates that, when taken separately, overall matching efficiency did not decrease in all labor markets over the time period under consideration.

For matter of comparison, Tables 5-4 and 5-5 contain the same estimates and additionally estimates that result from imposing constant returns to scale for each occupational group.

\section{[ INSERT TABles 5-4 AND 5-5 ABOUt HeRE. ]}

\section{Disaggregation by Age}

In the discussion about long-term unemployment, it is a stylized fact that older individuals are particularly likely to have problems in finding new employment and to have low matching rates. Therefore, many labor market programs target on unemployed of higher age. In the context of this paper, it is interesting to analyze the differences between different age groups with respect to the matching process. The conventional wisdom is that labor markets for young and middle aged individuals are a lot more dynamic than those faced by older individuals. The data used allow to distinguish flows into employment by age, additional to the employment status of matched individuals. In what follows, we first estimate matching functions separately for different age groups. Then we try to get an even more detailed view of the structure of labor markets by considering interactions between different age groups and occupations.

\footnotetext{
${ }^{36}$ The detailed results are not contained in the table, but are available from the authors upon request.
} 


\subsection{Matching by Different Age Cohorts}

In what follows, three age groups are considered which are defined as follows: young labor market participants between 16 and 25 years old (group 1), middle-aged (25-50 years old, group 2), and individuals older than 50 years (group 3). Table 6-1 lists the relative sizes and the relative sizes of flows by sources for the three age groups under consideration. It is striking, that only a tiny share, about 7 percent, of total matchings affect members of the oldest age group, which itself is makes up for more than 18 percent of the sample population. ${ }^{37}$ The same is true for hirings from employment. For hirings from non-employment, the discrepancy is even more pronounced: while more than 23 percent of non-employed belong to the older age group, only 7 percent of hirings from non-employed involve older workers. This strongly supports the conjecture that it becomes harder to find a match once one is older than 50 years, in particular from non-employment. Another interesting feature is that while the young group is only a fourth of the total population, and the middle aged constitute almost 57 percent, the remaining total matches are split about equally among the young and the middle-aged. Moreover, the middle aged capture more than half of all hirings from employment and non-employment. On the other hand, about half of hirings from non-employment involve young, whose share in the stock of nonemployed is a mere 22 percent. Moreover, the young make up for almost 58 percent of hirings from out of the labor force, which indicates that by far most of those entering the labor market are young individuals, potentially finding their first job. This indicates that indeed the most dynamic labor market in terms of flows and new hirings is the one for young individuals.

\section{[ INSERT TABLE 6-1 ABOUt HERE. ]}

Within the oldest age group, all hirings are about equally distributed among flows from employment, unemployment and out of the labor force. Roughly the same is true for the middle aged, with flows from unemployment being somewhat lower than flows from the other sources. In contrast to that, almost 57 percent of all matches of the young age group consist of flows from out of the labor force, a bit more than a quarter are flows from employment and the small remainder are flows from unemployment. This reflects the fact that most new matches in this age cohort stem from entry into the labor market after finishing education.

Table 6-2 contains estimation results for the benchmark matching function (3) by age groups and separately for all hirings and hirings from nonemployment. Compare first the results taking all hirings, but separately for

\footnotetext{
${ }^{37}$ Figure A2 in the appendix displays the development of the relative sizes of the three age groups over the entire observation period 1980 - 1995. Group sizes are quite stable over time with the share of young individuals decreasing slightly in favor of increases of the other two groups.
} 
each age group, as dependent variable and stocks of unemployed and vacancies as explanatory variables (models 20,21 and 22). ${ }^{38}$ It is interesting to note that the null of constant returns to scale of the matching function cannot be rejected for young and old (groups 1 and 3), while it can be rejected in favor of decreasing returns on the 1 percent level for middle aged. Moreover, the coefficients for the stock of unemployed are quite similar for all three age groups, with the one for the young being highest. This is not so for the vacancy coefficient which is significantly lower for the middle aged group than for the two other groups. The coefficient for the time trend is negative in all three groups. Surprisingly, in absolute terms, it is comparable to the aggregate results obtained earlier only for the oldest age group, while it is twice as large for the young and only half as large for the middle-aged. These results suggest that over time, matching efficiency decreased more for the old and especially for the young. Finally, the explanatory power of the stocks of unemployed and vacancies in a standard matching function is quite low for the old, suggesting that other forces, like public sector interventions, and labor market policies, might have helped to create matches which are not explained by the market forces reflected in the matching function.

\section{[ Insert TABle 6-2 ABout Here. ]}

Taking matches from non-employment as relevant flow measure, results are almost unchanged (models 23, 24 and 25). One noticeable difference is that the elasticity of hirings with respect to vacancies in the old age group is about 10 percent higher in this specification. Constant returns can now also be rejected for the young age group. Again the negative time trend is largest in absolute terms for the young and more than four times larger than the negative trend for the middle aged. The explanatory power is even lower in the specification with flows from non-employment for the old-age group, while it increases slightly for the young.

An interesting finding is that, regardless of the measure of new hirings taken as dependent variable, the unemployment elasticity of hirings is consistently larger than the vacancy elasticity for the young and the intermediate age group. The opposite is true for the old age group. This might indicate a relative demand shortage for old individuals, and relative supply shortages for young and middle-aged. Thus, this is indeed evidence for the claim that older individuals have a harder time in finding a match.

In order to check whether unemployment and vacancy elasticities are the same for all age groups, that is whether all age groups face identical matching technologies, the models identical to those in Table 6-2 have been estimated

\footnotetext{
${ }^{38}$ Note that strictly speaking, the flows are not regressed on the correct corresponding stocks, because neither the stock of unemployed per year and occupation is available by age groups, nor - trivially - the stock of vacancies. Nevertheless, we think that regressing matches on the stocks available can still reveal interesting information.
} 
as seemingly unrelated regressions for $m_{\text {all }}, m_{X}$ and $m_{U} \cdot{ }^{39}$ The null of identical unemployment and vacancy elasticities across groups, respectively, is rejected on the 1 percent level regardless of the measure of matches used. While also the null of identical vacancy elasticities across groups is rejected uniformly, the hypothesis of identical unemployment elasticities for all three age groups cannot be rejected at the 5 percent level. An interpretation for this might be that matches are determined more on the demand than on the supply side: while an additional job seeker creates the same amount of matches regardless of his age, an additional vacancy creates relatively more matches for old and young than for middle aged. In other words, firms trying to fill their vacancies are selective with respect to the age of their applicants. Taking up the argument of section 2.1, the markets for the middle-aged exhibit relatively more demand shortage than markets for young and old workers.

\subsection{The Interplay between Age and Occupation}

In order to get some deeper insights into the interactions between age and occupation, we replicate the previous analysis with controls for broad occupational groups separately for different age groups. As before, matching functions are estimated for different measures of flows as dependent variables. Table 6-3 presents the results for all hirings and the three age groups separately (models 26, 27 and 28). As before, the null that the matching function exhibits constant returns to scale can only be rejected in favor of decreasing returns for the intermediate age group. Coefficient estimates for the elasticities with respect to unemployed and vacancies, as well as the time trend coefficient are virtually unchanged to the results obtained without controlling for broad occupations. Thus, also the between group differences analyzed before are retained by and large. The differences in the occupation dummies among age groups are striking. As in the previous section, the unemployment elasticity is larger for young and middle-aged, while the vacancy elasticity is larger for the old, again indicating relative demand shortages for older workers.

The coefficients for given occupations differ substantially across age groups. In addition, the pattern of these differences varies across occupations. A possible explanation for the remarkable heterogeneity of the coefficients for occupation dummies across age groups is that there are life cycles for skills and that the structure of these life cycles varies from occupation to occupation. For instance, in manufacturing occupations and crafts (groups 2 and 3 ) young individuals have significantly more matches than the average over occupations, that is when individuals usually make an apprenticeship or finish an apprenticeship. Middle-aged in these occupations have significantly

\footnotetext{
${ }^{39}$ Detailed results are contained in Tables A6-2-1 and A6-2-2.
} 
lower matches than average, possibly because they typically stay with the same firm for a long time. On the other hand, members of the young and of the old age groups in technical, service and social occupations (groups 4, 5 and 7) have significantly fewer total hires than the average, while middle aged have significantly more. This indicates that for these occupations, key skills are only acquired later, or experience is more important for the attractivity of applicants. The strongest age effect is obtained for white collar occupations, where the middle-aged and the old have significantly more matches than the average over occupations. Skills of these occupations seem to depreciate less (or accumulate more) for older individuals than in other occupations. Finally, the strong positive effect of low skilled in the old age group might be explained through the absorption character of this broad occupational group for older workers. If the skills of individuals are not suitable for other occupations anymore, or if just because of their age individuals cannot find jobs in their old occupations, they can still accept jobs requiring little skills, concentrativeness and the like, classified as low skill occupations.

\section{[ INSERT TABLE 6-3 ABOUt HeRE. ]}

Table 6-4 repeats the same analysis matches from non-employment as dependent variable. ${ }^{40}$ The results remain almost unchanged. A noticeable difference is, again, a much higher elasticity of matches of the old age group with respect to vacancies. Moreover, the time trend for the middle-aged group is insignificant. The results on the coefficients for occupation dummies are qualitatively identical to those obtained before.

\section{[ Insert TABles 6-4 AND 6-5 ABOUt HeRE. ]}

In analogy to the previous subsection, we have estimated matching functions for the three age groups as seemingly unrelated regression estimation (SURE) separately for all nine occupation groups. ${ }^{41}$ The hypothesis that unemployment elasticities are the same for all three age groups cannot be rejected at the 5 percent level for primary (1), white collar (6), social (7) and health (8) occupations regardless of the measure for matches. With respect to the vacancy elasticity this is only true for service (5) and health (8) occupations. The null of both elasticities being the same across age groups can be rejected for all occupations.

\footnotetext{
${ }^{40}$ Table 6-5 contains results for matches from unemployment as dependent variable. The results differ substantially from the results obtained for the other two measures of matches. However, due to the conceptual and measurement problems with matches from unemployment as dependent variable mentioned before, we refrain from discussing the results and why they differ in detail. However, the reader is invited to form his own opinion by inspecting the Table.

${ }^{41}$ Detailed Results are available from the authors upon request.
} 
To conclude, the estimates for the matching function seem to differ substantially among age cohorts, suggesting quite distinct labor market conditions for individuals of different age. These differences become even more accentuated once additionally the occupational dimension is looked at, revealing a rather complex picture of the functioning of the matching process across labor markets.

\section{Education and Matching}

The discussion above indicated that there are indeed fundamental differences in the workings of labor markets for different age groups. This section takes a closer look at the matching functions for different educational cohorts. The modus operandi is similar to the one in the previous section: First, we look at matching functions estimated separately for different educational groups. Then, the interactions between education and occupation are examined more closely. Unfortunately, the data do not allow to discriminate between both dimensions, age and education, simultaneously. ${ }^{42}$

\subsection{Matching by Educational Groups}

Similar to the treatment of age cohorts, we divide individuals into three groups according to the education level they attained: We distinguish individuals with low educational backgrounds (group 1), defined as neither having successfully completed high-school (without Abitur), nor having completed an apprenticeship. Group 2 consists of individuals with an intermediate level of education, that is with either high-school diploma (Abitur), or completed apprenticeship, or both. Finally, we assort all individuals with a university degree or a degree from an applied university or polytechnic (Fachhochschule) into a high education group (group 3).

Table 7-1 presents summary statistics on group sizes and the flows from the different sources as obtained for the different educational groups under consideration. More than half of all hirings are made up for by the intermediate education group, while this group constitutes more than 60 percent of the population. ${ }^{43}$ Less than 15 percent of total matches can be traced back to highly educated individuals who make up for less than 12 percent of all individuals. That is, with respect to their group sizes, highly educated and less educated are overrepresented in total matchings, the intermedi-

\footnotetext{
${ }^{42}$ Again, strictly speaking, the flows are not regressed on the correct corresponding stocks, because neither the stock of unemployed per year and occupation is available by education groups, nor - trivially - the stock of vacancies.

${ }^{43}$ Figure A3 in the appendix displays the development of the relative sizes of the educational groups over the entire observation period 1980 - 1995. Group sizes are relatively stable with the share of individuals with low education decreasing somewhat over time in favor of increases of the other two groups.
} 
ate education group is underrepresented. This changes when one considers different measures of hirings. When looking at job-to-job matches, more than 65 percent can be attributed to individuals of intermediate education, whose share of employed is about 62 percent. About a fifth of hirings from employment go to individuals of low education, who represent around 27 percent of employed, and the rest of about 14 percent of job-to-job matches involve highly educated, while only 11 percent of employed are belonging to this group. Thus, groups 2 and 3 are overrepresented, group 1 forms fewer hirings from employment as would correspond to its size. This somewhat contradicts the conventional wisdom of the highly educated making up for the bulk of job-to-job changes.

Surprisingly, when it comes to hirings from non-employment, less educated form more matches (almost 41 percent) than would be expected from their share of non-employed (less than 34 percent). On the other hand, members of the intermediate and the high group form fewer (44\%) and much fewer $(14.6 \%)$ matches than would be expected from their shares of the pool of employed (46 and almost 20 percent, respectively). This indicates that those with low education actually form more matches from non-employment than would be expected from their relative group size. This effect is even more pronounced when matches from out of the labor force are considered. The low education group, which is about 27 percent of the population (and less than 34 percent of non-employed), contributes almost 48 percent of the flows, while intermediate education only contributes to less than 37 percent but constitutes more than 60 percent of all individuals (and 46 percent of non-employed). Highly educated create relatively more matches from out of the labor force than their relative size (15.5 percent versus 11.84 percent), but less than their proportion of non-employment (19.8 percent). This suggests that individuals with low education exhibit the lowest attachment to the labor market, and that they revise their participation decision more often than more educated people.

\section{[ INSERT TABLE 7-1 ABOUT HERE. ]}

Moreover, within the low education group, hirings from out of the labor force represent almost two thirds of all matches of this group, with matches from employment being a mere 18 percent. This means that the probability of having to go through an unemployment spell or even some period of nonparticipation is very high for members of this group. This pattern changes for intermediate education. More than 40 percent of all matches of this group are job-to-job matches, more than 27 percent are matches from unemployment. Surprisingly, the high education group has a distribution of all hirings that lies in between the two other groups. Particularly noteworthy is that a good 30 percent of their new hirings are matches from employment, while almost 50 percent are hirings from out of the labor force. Intuitively 
this means that highly educated either switch jobs directly or stop participating for some time (possibly living of their bonuses) before entering a new employment relation, while only a fifth goes through an unemployment spell before forming a new match.

The standard matching function is regressed for flows for three different educational groups. The results for matching functions for all flows $m_{\text {all }}$ and hires from non-employment $m_{X}$ are presented in Table 7-2. Interestingly, the hypothesis that the matching function exhibits constant returns to scale can only be rejected in favor of decreasing returns to scale for the matching function estimated for the intermediate group using all hires. Regardless of the measure used as dependent variable, the group of low education produces the highest coefficient for the stock of unemployed and the lowest coefficient for vacancies. This indicates that an additional job seeker in this group creates a new match with a relatively higher probability than in the other groups. The opposite is true for a person in the intermediate group. On the other hand, an additional vacancy creates relatively fewer matches in the low group than in the high, and in particular the intermediate group.

\section{[ INSERT TABLE 7-2 ABOUT HERE. ]}

The interpretation for this is straightforward. A given vacancy targets mostly intermediately and highly educated individuals, thus produces relatively more matches for members of these groups. On the other hand, variation in the stock of unemployment explains most matches for the low educated. This can either mean that this group is particularly affected by

cyclical variations or that the labor market for this group is very dynamic in the sense that many matches split up after a short period of time, therefore creating a lot of variation in both matches and the stock of unemployed. Moreover, group 1 also exhibits a negative time trend that is about three times as large as the trend for the other groups, regardless of the dependent variable used, which could be taken as an indication for decreasing labor market efficiency for these people, or even a sign for skill biased technological change.

\subsection{Educational Groups and Occupational Differences}

In a similar fashion to the treatment of disaggregation by age, we repeat the estimations of empirical matching functions for different educational levels with controls for broad occupational groups. Table 7-3 summarizes the findings for regressing total hirings in the standard specification including occupational dummies. The coefficient estimates for stocks of job seekers and vacancies are similar to the ones obtained with the specification without occupations. The elasticity of matches with respect to vacancies is somewhat higher in this specification, about 10 percent higher in the group with low 
education attainment, about 7 percent higher in the high education group, and about 3 percent in the intermediate cohort. Again, the time trend is negative for low and intermediate education, but insignificantly positive for individuals with high education. The null of constant returns to scale of the matching function can be rejected for intermediate and high education groups in favor of decreasing returns.

As in the preceeding section, we repeated the estimation of the models in Table 7-2 using the method of seemingly unrelated regression. As for age groups, the null hypothesis of identical unemployment and vacancy elasticities for matches of either definition across education groups, respectively, can be rejected at any reasonable level. ${ }^{44}$ Moreover, also the hypotheses of either identical vacancy elasticities for all groups or identical unemployment elasticities for all groups can as well be rejected.

\section{[ INSERT TABLE 7-3 ABOUT HERE. ]}

Once again, the occupation effects are interesting. As compared to the average over all occupations, manufacturing occupations (group 2) exhibit relatively more matches for individuals with low education, but fewer for individuals with intermediate or high education attainment. Similarly, low and middle education groups create more matches in crafts (group 3) than the average, high education leads to fewer matches. Exactly the opposite is true for technical occupations (group 4), service and white collar occupations (groups 5 and 6), and social and health related occupations (groups 7 and 8 ). In these occupations, low education exhibits lower matching rates (in particular for technical and social occupations). On the other hand, intermediate and in particular high education leads to more matches than average, where the positive effects are strongest for technical, white collar and social occupations. Primary occupations (group 1) form fewer matches in general, regardless of the occupation, while the negative effect is insignificant for high and low education. Oddly, in low skilled occupations (group 9), high and low education lead to more matches than on average, while intermediate education exhibits fewer matches. Most of these occupation effects probably have to do with the fact that the structure of skill requirements differs systematically across occupations and thus determines the number of flows in different education groups as education is systematically related with the skills required.

Table 7-4 presents the results for matchings from non-employment as dependent variable. ${ }^{45}$ The coefficient estimates are quite similar to those obtained before, with the exception that the unemployment elasticity for

\footnotetext{
${ }^{44}$ See Tables A7-2-1 and A7-2-2 for detailed results obtained with SURE.

${ }^{45}$ Table 7-5 contains the results for hirings from unemployment as dependent variable. The results differ substantially from those obtained with all hirings and hirings from nonemployment, but as before we forbear from a detailed interpretation.
} 
the low education group is about 7 percent and for the intermediate group about 4 percent higher than when regressed for all hirings. Constant returns to scale can be rejected for all three education groups. However, while this is done in favor of decreasing returns for intermediate and high education, the matching function for low education seems to exhibit increasing returns to scale. The pattern of interactions between education and occupation, captured by the dummy coefficient estimates is virtually identical apart from minor differences concerning significance of the coefficients.

Similar to the proceeding for disaggregation by age, matching functions for the three education groups have been estimated as seemingly unrelated regressions (SURE) separately for all nine occupation groups. ${ }^{46}$ The hypothesis that unemployment elasticities are the same for all three age groups cannot be rejected at the 5 percent level for primary (1), white collar (6), social (7) occupations regardless of the measure for matches. ${ }^{47}$ The null for identical vacancy elasticity for all education groups can be rejected at the 5 percent level for all occupations. The same is true for the null of both elasticities being the same across educational groups.

[ INSERT TABLES 7-4 AND 7-5 ABOUt HeRE. ]

\section{Conclusion}

Summarizing the investigations of empirical matching functions disaggregated along different dimensions, the most striking, although not too surprising, finding is the apparent heterogeneity of the matching technology for different categories of jobs and workers. While the results presented for the aggregate matching function fit nicely into the findings reported in the literature, this aggregate matching function seems to be made up of very distinct matching functions on very distinct labor markets with very distinct characteristics of the matching process. The stylized results are the following: In general with only few exceptions, constant returns to scale of the matching function is rejected on the aggregate as well as on disaggregate levels. On the aggregate level, we find evidence for decreasing returns to scale. On the occupational level, matching technologies for some occupations exhibit increasing returns to scale while at the same time those for other occupations exhibit decreasing returns. While for some occupations, the elasticity of matches with respect to the stock of job seekers is relatively high, it is relatively low for others. The same goes for the elasticity with respect to vacancies.

Also, matching technologies are quite heterogenous for members of different age and education groups indicating that labor markets are heterogeneous also along these dimensions. We find evidence that suggests that

\footnotetext{
${ }^{46}$ Detailed Results are available from the authors upon request.

${ }^{47}$ Note the similarities with the results for age.
} 
older workers are involved in fewer matches than young and middle-aged. However, the results differ across occupations, leading to the impression of different systematic age effects on matching for different types of skills.

The main implication from these findings is a caveat on the usefulness of an aggregate matching function to explain the working of the labor market as a whole since it discards a lot of potentially important information. In particular, for the conduct of economic policies it might be indispensable to look beyond the aggregate level in order to have a clear understanding of the structure of labor markets, and the pattern of frictions at work. 


\section{References}

[1] Anderson, Patricia M. and Simon M. Burgess (2000): "Empirical Matching Functions: Estimation and Interpretation Using State-Level Data", Review of Economics and Statistics 82(1), pp. 93-102.

[2] Bender, Stefan, Anette Haas and Christoph Klose (2000): "IAB Employment Subsample 1975 - 1995. Opportunities for Analysis Provided by the Anonymised Subsample", IZA Discussion Paper 117, (February).

[3] Bender, Stefan, Juergen Hilzendegen, Goetz Rohwer and Helmut Rudolph (1996): "Die IAB-Beschaeftigtenstichprobe 1975 - 1990", Beitraege zur Arbeitsmarkt- und Berufsforschung 197.

[4] Berman, Eli, John Bound and Zvi Griliches (1994): "Changes in the Demand for Skilled Labor Within U.S. Manufacturing: Evidence from the Annual Survey of Manufactures", Quarterly Journal of Economics 109(2) (May), pp. 367-397.

[5] Blanchard, Olivier J. and Peter Diamond (1989): "The Beveridge Curve", Brookings Papers on Economic Activity 1:1989, pp. 1-76.

[6] Broersma, Lourens and Jan C. Van Ours (1999): "Job Searchers, Job Matches and the Elasticity of Matching", Labour Economics 6, pp. 7793.

[7] Burda, Michael and Stefan Profit (1996): "Matching Across Space: Evidence on Mobility in the Czech Republic", CEPR Discussion Paper 1364 (March).

[8] Burda, Michael and Charles Wyplosz (1994): "Gross Worker and Job Flows in Europe", European Economic Review 38, pp. 1287-1315.

[9] Burgess, Simon M. (1993): "A Model of Competition Between Unemployed and Employed Job Searchers", Economic Journal 103, pp. 1190-1204.

[10] Burgess, Simon and Stefan Profit (2001): "Externalities in the Matching of Workers and Firms in Britain", mimeo, University of Bristol.

[11] Buttler, Friedrich and Ulrich Cramer (1991): "Entwicklung und Ursachen von mis-match-Arbeitslosigkeit in Westdeutschland", Mitteilungen aus Arbeits- und Berufsforschung, 24(3), pp. 483-500.

[12] Coles, Melvyn G. and Eric Smith (1996): "Cross Section Estimation of the Matching Function: Evidence from England and Wales", Economica 63(252), pp. 589-597. 
[13] Coles, Melvyn G. and Eric Smith (1998): "Marketplaces and Matching", International Economic Review 39(1) (February), pp. 239-254.

[14] Diamond, Peter (1982): "Wage Determination and Efficiency in Search Equilibrium", Review of Economic Studies 49(2) (April), pp. 217-227.

[15] Entorf, Horst (1998): Mismatch Explanations of European Unemployment, A Critical Evaluation, Springer, Berlin.

[16] Fahr, René and Uwe Sunde (2001): "Endogenous Hiring Behavior in Empirical Matching Functions", IZA Discussion Paper 320 (June).

[17] Guilkey, David K., C.A. Knox Lovell and Robin Sickles (1983): "A Comparison of the Performance of Three Flexible Functional Forms", International Economic Review 24(3) (October), pp. 591-616.

[18] Haisken-DeNew, John P. and Christoph M. Schmidt (1997): "Interindustry and Interregion Differentials: Mechanics and Interpretation", Review of Economics and Statistics 79(3) (August), pp. 516-521.

[19] Hall, Robert (1989): "Comment on Blanchard and Diamond", Brookings Papers on Economic Activity 1:1989, pp. 61-71.

[20] Jackman, Richard, Richard Layard and S. Savouri (1991): "Mismatch: A Framework for Thought", in: Padoa-Schioppa, Fiorella (ed.) Mismatch and Labor Mobility, Cambridge University Press, Cambridge U.K., ch. 2.

[21] Maddala, G.S. and Shaowen Wu (1999): "A Comparative Study of Unit Root Tests with Panel Data and a New Simple Test", Oxford Bulletin of Economics and Statistics 61(0) Special Issue (November), pp. 631-652.

[22] Moulton, Brent R. (1990): "An Illustration of a Pitfall in Estimating the Effects of Aggregate Variables on Micro-Units", Review of Economics and Statistics 72(2), pp. 334-338.

[23] Mumford, Karen and Peter N. Smith (1999): "The Hiring Function Reconsidered: On Closing the Cycle", Oxford Bulletin of Economics and Statistics 61(3), 343-364.

[24] Van Ours, Jan (1991): "The Efficiency of the Dutch Labour Market in Matching Unemployment and Vacancies", De Economist 139, pp. 358-378.

[25] Van Ours, Jan and Geerd Ridder (1995): "Job Matching and Job Competition: Are Lower Educated Workers at the Back of Job Queues?", European Economic Review 39 (December), pp. 1717-31. 
[26] Petrongolo, Barbara and Christopher Pissarides (2001): "Looking into the Black Box: A Survey of the Matching Function", Journal of Economic Literature, forthcoming.

[27] Phillips, Peter C.B. and Hyunsgsik R. Moon (2000): "Nonstationary Panel Data Analysis: An Overview of Some Recent Developments", Econometric Reviews 19(3), pp. 263-286.

[28] Pissarides, Christopher (1979): "Job Matchings with State Employment Agencies and Random Search", Economic Journal 89 (December), pp. 818-833.

[29] Pissarides, Christopher (1986): "Unemployment and Vacancies in Britain", Economic Policy 3, pp. 499-559.

[30] Pissarides, Chistopher (2000): Equilibrium Unemployment Theory, 2nd ed., MIT Press, Cambridge Massachusetts.

[31] Storer, P. (1994): "Unemployment Dynamics and Labour Market Tightness", Journal of Applied Econometrics 9, pp. 389-419.

[32] Warren, Ronald S. (1996): "Returns to Scale in a Matching Model of the Labor Market", Economics Letters 50, pp. 135-142.

[33] Yashiv, Eran (2000): "The Determinants of Equilibrium Unemployment", American Economic Review 90(5) (December), pp. 1297-1322. 


\section{A Data Appendix}

The data used for the empirical analysis are yearly data for Western Germany disaggregated into 83 occupational groups. They are reported in official labor statistics as published in the Amtliche Nachrichten der Bundesanstalt fuer Arbeit. For all estimations the occupational group collecting all unspecified occupations (other occupations), trainees and apprentices (group 98 ) is dropped, which leaves us with 82 occupational groups throughout the empirical analysis. The occupational groups were further clustered in nine broad occupational groups (see Table A3 for details). The data include information on unemployment, vacancies, employment levels as well as flows from registered vacancies to employment. The stock data are reported as measured on the 30th of September of each year as reference date. The flows from registered vacancies to employment are reported as the flows aggregated over one year. As an further attempt to reproduce the relevant stocks for job seekers and vacancies for the entire period and check the robustness of our results, the stocks of occupational measures as reported on the reference date of each year are augmented by a correction factor. This factor is obtained by dividing the aggregate flows aggregated over an entire period by the stock of the aggregate measure at the reference date (30.09.). This practice is necessary due to the lack of detailed vacancy flows data on the disaggregate (occupational) level.

The hirings were constructed using an anonymized representative 1\% sample of Western German social security records from the German Institute for Employment Research (IAB). The basis of the IAB employment subsample 1975-1995 is the integrated notifying procedure for health insurance, statutory pension scheme and unemployment insurance which is regulated through German legislation. The employment statistics include all employees obliged to pay social insurance contributions and covers about $80 \%$ of all employed persons in Western Germany. In total this data set includes 6,711,153 notifications of 483,327 Western Germans (calculated on the basis of final notifications) (cf. Bender et al., 2000). The data contain information on individual characteristics, as well as a firm identifier. They are supplemented by person-related information on periods in which the Federal Employment Service paid benefits from the benefits recipients file. With this information the hirings from different sources could be identified. A flow from employment to employment is identified by observing a change in the firm identifier while an individual is employed (pays social security contributions) from on year to another. There is a negligible measurement error, because a change in the firm identifier could result from a merger or a move between different plants of the same firm. A hiring from unemployment is identified by observing in one year the notification of an individual as stemming from the benefits recipients file (characterizing the individual as an unemployment benefits receiver) while observing the information for the 
individual in the next year in the employed sample. Accordingly a flow from out of the labor force to employment is identified by missing information on the status in one year (neither employed nor unemployed) while finding this individual in the employed (social security contribution paying) sample in the next year. Because the employment status is identified by social security payments, self-employed and individuals in low-paid jobs which are exempt from social security contributions show up as being out of the labor force. Thus, some flows measured as hirings from out of the labor force are in fact hirings from employment.

In addition, there are some sources of measurement error in distinguishing flows from out of the labor into employment from flows from unemployment. This is due to the fact that there are three sources of mistaking an unemployed as an individual from out of the labor force. Firstly, information from the benefits recipients file could only be matched to the data from the employment subsample when the recipient had a social security number. But between $1.4 \%$ and $8 \%$ of all notifications in the benefits recipients file are reported without a social security number (see Bender et al. 1996). The hiring from an unemployed who received unemployment benefits without having a social security number would be mistaken as a hiring from out of the labor force. Secondly, certain preconditions have to be fulfilled to be entitled to receive unemployment benefits. This means that some people are unemployed without receiving unemployment benefits and could therefore not be identified as unemployed in the data set. Finally the benefit recipients file does not record all benefits paid by the Federal Employment Service. Some payments related to measure of active labor market policies did not show up in the benefits recipients file (for a detailed list see Bender et al. 1996). All three source of measurement error lead to a considerable underreporting of hirings from unemployment while measuring to many hirings from out to the labor force.

Because the anonymization procedure leads to missings in the codings of occupations which are not found in the official statistics, only the relative hirings in the sub-sample are regarded as representative. In order to obtain absolute values the relative numbers of hirings for each occupations were multiplied by the respective occupational employment levels from aggregate labor statistics.

To keep the data comparable to the aggregated data from labor statistics and due to some measurement error in the data in the years before 1980 we retain all observations from 1980 to 1995, with the exception of notifications for a second job, for the construction of total hirings per year. The hirings for a specific occupation for a specific year were calculated by comparing all employees at the 30th of September of each year in a specific occupation and with a specific firm identifier to the values of these variables and the variable denoting the employment status (stating whether the observation for an individual is taken from the employment statistics or from the benefits 
recipients file) at the previous reference date. A problem of this procedure is that one misses short employment spells which take place within the year. The 30th of September was chosen to make the hirings information comparable to the data on the occupational level. 
TABLE A3: OCCUPATIONAL GROUP DEFINITIONS

\begin{tabular}{|c|c|c|}
\hline Occupation & $\begin{array}{c}\text { Occupational codes } \\
\text { (2-digit, from official } \\
\text { statistics) }\end{array}$ & $\begin{array}{c}\text { Broad } \\
\text { occupational } \\
\text { groups* }\end{array}$ \\
\hline farmer, fisher & 01 & 1 \\
\hline agricultural administrator & 03 & 1 \\
\hline $\begin{array}{l}\text { helper in the agricultural sector, agricultural } \\
\text { workers, stockbreeding professions }\end{array}$ & 04 & 1 \\
\hline gardener, florist & 05 & 1 \\
\hline forester and huntsman & 06 & 1 \\
\hline miner and related professions & 07 & 2 \\
\hline exhauster of mineral resources & 08 & 2 \\
\hline mineral rehasher, mineral burner & 09 & 2 \\
\hline stone processor & 10 & 2 \\
\hline ,producer of building materials & 11 & 2 \\
\hline ceramicist, glazier & 12 & 2 \\
\hline glazier, glass processor, glass refiner & 13 & 3 \\
\hline chemical worker & 14 & 2 \\
\hline polymer processor & 15 & 2 \\
\hline paper producer & 16 & 2 \\
\hline printer & 17 & 2 \\
\hline woodworker, wood processor & 18 & 3 \\
\hline metal worker & 19 & 2 \\
\hline moulder, caster, semi-metal cleaner & 20 & 2 \\
\hline metal press workers, metal formers & 21 & 2 \\
\hline turner, cutter, driller, metal polisher & 22 & 2 \\
\hline metal burnisher, galvanizer, enameler & 23 & 2 \\
\hline welder, solderer, riveter, metal gluter & 24 & 2 \\
\hline steel smith, copper smith & 25 & 2 \\
\hline plumber, plant locksmith & 26 & 3 \\
\hline locksmith, fitter & 27 & 3 \\
\hline mechanic & 28 & 3 \\
\hline toolmaker & 29 & 2 \\
\hline metal precision-workers, orthodontists, opticians & 30 & 3 \\
\hline electricians & 31 & 3 \\
\hline assemblers and metal related professions & 32 & 2 \\
\hline spinner, ropemaker & 33 & 2 \\
\hline weaver, other textile producer & 34 & 2 \\
\hline tailor, sewer & 35 & 2 \\
\hline textile dyer & 36 & 2 \\
\hline leather and fur manufacturers, shoemaker & 37 & 2 \\
\hline baker, confectioner & 39 & 3 \\
\hline butcher, fishworkmansip and related & 40 & 3 \\
\hline cooks, convenience food preparatory & 41 & 3 \\
\hline brewer, manufacturer for tobacco products & 42 & 2 \\
\hline milk/fat processor, nutriments producer & 43 & 2 \\
\hline bricklayer, concrete builder & 44 & 3 \\
\hline carpenter, roofer, spiderman & 45 & 3 \\
\hline $\begin{array}{l}\text { road/track constructors, demolisher, culture } \\
\text { structurer }\end{array}$ & 46 & 3 \\
\hline helper in the construction sector & 47 & 3 \\
\hline plasterer, tiler, glazier, screed layer & 48 & 3 \\
\hline interior designer, furniture supplier & 49 & 3 \\
\hline joiner, modeler, cartwright & 50 & 3 \\
\hline painter, varnisher and related professions & 51 & 3 \\
\hline goods tester, consignment professions & 52 & 2 \\
\hline unskilled worker & 53 & 9 \\
\hline machinist and related professions & 54 & 2 \\
\hline
\end{tabular}


Table A3 continued

\begin{tabular}{|c|c|c|}
\hline engineer, architect & 60 & 4 \\
\hline chemist, physicist & 61 & 4 \\
\hline technician & 62 & 4 \\
\hline technical specialist & 63 & 4 \\
\hline merchandise manager & 68 & 5 \\
\hline banking professional, insurance merchant & 69 & 6 \\
\hline $\begin{array}{l}\text { merchant/ specialist in conveyance, tourism, other } \\
\text { services }\end{array}$ & 70 & 6 \\
\hline conductor, driver, motorist & 71 & 5 \\
\hline navigator, ship engineer, water/air traffic professions & 72 & 5 \\
\hline mail distributer & 73 & 5 \\
\hline storekeeper, worker in storage and transport & 74 & 9 \\
\hline manager, consultant, accountant. & 75 & 6 \\
\hline member of parliament, association manager & 76 & 6 \\
\hline accounting clerk, cashier, data processing expert & 77 & 6 \\
\hline clerk, typist, secretary & 78 & 6 \\
\hline plant security, guard, gate keeper, servant & 79 & 5 \\
\hline $\begin{array}{l}\text { other security related professions, health caring } \\
\text { professions }\end{array}$ & 80 & 5 \\
\hline law related professions & 81 & 5 \\
\hline publicist, translator, librarian & 82 & 7 \\
\hline artist and related professions & 83 & 7 \\
\hline physician, dentist, apothecaries & 84 & 8 \\
\hline nurse, helper in nursing, receptionist and related & 85 & 8 \\
\hline social worker, care taker & 86 & 7 \\
\hline professor, teacher & 87 & 7 \\
\hline scientist & 88 & 7 \\
\hline helper for cure of souls and cult & 89 & 7 \\
\hline beauty culture & 90 & 8 \\
\hline guest assistant, steward, barkeeper & 91 & 5 \\
\hline domestic economy, housekeeping & 92 & 5 \\
\hline cleaning industry related professions & 93 & 5 \\
\hline trainee, apprentice & 98 & $* *$ \\
\hline $\begin{array}{l}\text { *The occupations are merged into the following broad } \\
\text { (1) Primary sector } \\
\text { (2) Industry and manufacturing } \\
\text { (3) Crafts } \\
\text { (4) Technical } \\
\text { (5) Service } \\
\text { (6) White collar/ clerical } \\
\text { (7) Social and cultural } \\
\text { (8) Health } \\
\text { (9) Low skilled }\end{array}$ & nal gr & \\
\hline
\end{tabular}




\section{B Tables and Figures}

Table 4-1: Descriptive Statistics (Aggregate Sample)

Table 4-2: Empirical Aggregate Matching Functions

Table 4-3: Empirical Aggregate Matching Functions by Sources of Flows

Table 5-1: Empirical Aggregate Matching Functions by Sources, Occupational Dummies

Table 5-2: Empirical Matching Functions by Broad Occupational Group $\left(m_{\text {all }}, m_{X}\right)$

Table 5-3: Empirical Matching Functions by Broad Occupational Group $\left(m_{\text {all }}, m_{U}\right)$

Table 5-4: Empirical Matching Functions by Broad Occupational Group $\left(m_{\text {all }}\right)$ constraint to $\mathrm{CRS}$

Table 5-5: Empirical Matching Functions by Broad Occupational Group $\left(m_{X}\right)$ constraint to CRS

Table 6-1: Descriptive Statistics (Aggregate, Age Groups)

Table 6-2: Empirical Aggregate Matching Functions by Sources of Flows and Age Groups

Table 6-3: Empirical Aggregate Matching Functions $\left(m_{\text {all }}\right)$ by Age Groups, Occupational Dummies

Table 6-4: Empirical Aggregate Matching Functions $\left(m_{X}\right)$ by Age Groups, Occupational Dummies

Table 6-5: Empirical Aggregate Matching Functions $\left(m_{U}\right)$ by Age Groups, Occupational Dummies

Table 7-1: Descriptive Statistics (Aggregate, Educational Groups)

Table 7-2: Empirical Aggregate Matching Functions by Sources of Flows and Educational Groups

Table 7-3: Empirical Aggregate Matching Functions $\left(m_{\text {all }}\right)$ by Age Groups, Occupational Dummies

Table 7-4: Empirical Aggregate Matching Functions $\left(m_{X}\right)$ by Age Groups, Occupational Dummies

Table 7-5: Empirical Aggregate Matching Functions $\left(m_{U}\right)$ by Age Groups, Occupational Dummies 
Table A4-2-1: Empirical Aggregate Matching Functions, Explanatory Variables Lagged 1 Period

Table A4-2-2: Empirical Aggregate Matching Functions, Explanatory Variables Lagged 2 Periods

Table A4-2-3: Empirical Aggregate Matching Functions, CRS Imposed

Table A4-3-1: Empirical Aggregate Matching Functions by Sources of Flows, Explanatory Variables Lagged 1 Period

Table A4-3-2: Empirical Aggregate Matching Functions by Sources of Flows, Explanatory Variables Lagged 2 Periods

Table A4-3-3: Empirical Aggregate Matching Functions by Sources of Flows, CRS Imposed

Table A4-3-4: Empirical Aggregate Matching Functions by Sources of Flows, 2-way F.E. Model

Table AA4-2: Empirical Aggregate Matching Functions, Adjusted Explanatory Stocks

Table AA4-3: Empirical Aggregate Matching Functions by Sources of Flows, Adjusted Explanatory Stocks

Table A6-2-1: Empirical Aggregate Matching Functions by Sources of Flows and Age Groups, SURE $\left(m_{\text {all }}, m_{X}\right)$

Table A6-2-2: Empirical Aggregate Matching Functions by Sources of Flows and Age Groups, SURE $\left(m_{a l l}, m_{U}\right)$

Table A7-2-2: Empirical Aggregate Matching Functions by Sources of Flows and Educational Groups, $\operatorname{SURE}\left(m_{\text {all }}, m_{X}\right)$

Table A7-2-2: Empirical Aggregate Matching Functions by Sources of Flows and Educational Groups, SURE $\left(m_{\text {all }}, m_{U}\right)$

Figure 1: Sizes of Nine Broad Occupational Groups 1980-1995

Figure 2: Relative Age Group Sizes 1980-1995

Figure 3: Relative Educational Group Sizes 1980-1995 
TABle 4-1: Descriptive Statistics (Aggregate SAMPLE)

\begin{tabular}{|c|c|c|c|}
\hline & & $\begin{array}{c}\text { Average } \\
1980-1995\end{array}$ & Share \\
\hline Labor force & & $23,363,770$ & $100 \%$ \\
\hline Employement levels & & $21,500,186$ & \\
\hline Unemployed & & $1,863,583$ & $7.97 \%$ \\
\hline Vacancies & & 211,377 & $0.90 \%$ \\
\hline \multicolumn{4}{|l|}{ Hirings } \\
\hline total: & $m_{\text {all }}$ & $3,475,697$ & $100 \%$ \\
\hline from nonemployment: & $m_{X}$ & $2,384,188$ & $68.60 \%$ \\
\hline from employment: & $\boldsymbol{m}_{E}$ & $1,091,509$ & $31.40 \%$ \\
\hline from unemployment: & $m_{U}$ & 800,725 & $23.04 \%$ \\
\hline from out of labor force: & $m_{O L}$ & $1,583,460$ & $45.56 \%$ \\
\hline from registered vacancies: & $m_{R}$ & $2,038,274$ & $58.64 \%$ \\
\hline
\end{tabular}




\section{Table 4-2: Empirical Aggregate Matching FunCtions}

\begin{tabular}{|c|c|c|c|c|c|c|c|}
\hline & $(1)^{*}$ & $(2)^{* *}$ & (3) & (4) & $(5)$ & $(6)$ & (7) \\
\hline Log of registered unemployed in & 0.447 & 0.446 & 0.446 & 0.460 & 0.460 & 0.442 & 0.456 \\
\hline the occupation: $\ln U$ & $(0.018)$ & $(0.169)$ & $(0.025)$ & $(0.025)$ & $(0.021)$ & $(0.019)$ & $(0.022)$ \\
\hline Log of registered vacancies in & 0.409 & 0.379 & 0.411 & 0.367 & 0.399 & 0.415 & 0.404 \\
\hline the occupation: $\ln V$ & $(0.016)$ & $(0.017)$ & $(0.022)$ & $(0.024)$ & $(0.019)$ & $(0.017)$ & $(0.020)$ \\
\hline Linear time trend & -0.032 & -0.031 & & & -0.054 & -0.032 & -0.055 \\
\hline & $(0.003)$ & $(0.003)$ & & & $(0.016)$ & $(0.004)$ & $(0.016)$ \\
\hline Time dummies & No & No & Yes*** & Yes*** & No & No & No \\
\hline $\begin{array}{l}\text { Dummies for } 9 \text { broad } \\
\text { occupational groups }\end{array}$ & No & Yes & No & Yes & No & No & No \\
\hline Log GDP & & & & & $\begin{array}{c}0.922 \\
(0.635)\end{array}$ & & $\begin{array}{c}0.922 \\
(0.641)\end{array}$ \\
\hline Log GDP-growth & & & & & & $\begin{array}{c}0.011 \\
(0.016)\end{array}$ & $\begin{array}{c}0.010 \\
(0.016)\end{array}$ \\
\hline $\mathrm{R}^{2}$ & 0.858 & 0.878 & 0.860 & 0.879 & 0.858 & 0.863 & 0.864 \\
\hline Observations & 1311 & 1311 & 1311 & 1311 & 1311 & 1147 & 1147 \\
\hline
\end{tabular}

\section{Table 4-3: Empirical Aggregate Matching Functions By Sources of Flows}

Dependent Variable: Hirings (per occupation and year) by sources

\begin{tabular}{|c|c|c|c|c|c|c|}
\hline & $\begin{array}{l}(8) \\
\text { total }\end{array}$ & $\begin{array}{c}(9) \\
\text { from non- } \\
\text { employment } \\
\boldsymbol{m}_{X}\end{array}$ & $\begin{array}{c}(10) \\
\text { from } \\
\text { employment } \\
\boldsymbol{m}_{E}\end{array}$ & $\begin{array}{c}(11) \\
\text { from un- } \\
\text { employment } \\
\boldsymbol{m}_{U}\end{array}$ & $\begin{array}{c}(12) \\
\text { from out of } \\
\text { labor force } \\
\boldsymbol{m}_{O L}\end{array}$ & $\begin{array}{c}(13) \\
\text { from } \\
\text { registered } \\
\text { vacancies } \\
\boldsymbol{m}_{\boldsymbol{R}}{ }^{*}\end{array}$ \\
\hline Log unemployed: $\ln U$ & $\begin{array}{c}0.447 \\
(0.018)\end{array}$ & $\begin{array}{c}0.450 \\
(0.018)\end{array}$ & $\begin{array}{c}0.460 \\
(0.025)\end{array}$ & $\begin{array}{c}0.520 \\
(0.030)\end{array}$ & $\begin{array}{c}0.441 \\
(0.017)\end{array}$ & $\begin{array}{c}0.614 \\
(0.040)\end{array}$ \\
\hline $\begin{array}{l}\text { Log registered } \\
\text { vacancies: } \ln V\end{array}$ & $\begin{array}{c}0.409 \\
(0.016)\end{array}$ & $\begin{array}{c}0.413 \\
(0.015)\end{array}$ & $\begin{array}{c}0.417 \\
(0.022)\end{array}$ & $\begin{array}{c}0.346 \\
(0.023)\end{array}$ & $\begin{array}{c}0.451 \\
(0.015)\end{array}$ & $\begin{array}{c}0.320 \\
(0.035)\end{array}$ \\
\hline Linear time trend & $\begin{array}{l}-0.032 \\
(0.003)\end{array}$ & $\begin{array}{l}-0.036 \\
(0.003)\end{array}$ & $\begin{array}{l}-0.022 \\
(0.004)\end{array}$ & $\begin{array}{c}-0.031 \\
(0.004)\end{array}$ & $\begin{array}{l}-0.033 \\
(0.004)\end{array}$ & $\begin{array}{l}-0.011 \\
(0.007)\end{array}$ \\
\hline $\begin{array}{l}\mathrm{R}^{2} \\
\text { Observations } \\
\mathrm{H}_{0} \text { : constant returns to } \\
\quad \text { scale }\end{array}$ & $\begin{array}{c}0.858 \\
1311 \\
\mathrm{~F}(1,1307) \\
128.72\end{array}$ & $\begin{array}{c}0.839 \\
1310 \\
\mathrm{~F}(1,1306) \\
98.38\end{array}$ & $\begin{array}{c}0.810 \\
1308 \\
\mathrm{~F}(1,1304) \\
67.89\end{array}$ & $\begin{array}{c}0.710 \\
1298 \\
\mathrm{~F}(1,1294) \\
54.66\end{array}$ & $\begin{array}{c}0.836 \\
1308 \\
(1,1304) \\
53.83\end{array}$ & $\begin{array}{c}0.616 \\
640 \\
\mathrm{~F}(1,636) \\
6.29\end{array}$ \\
\hline
\end{tabular}




\section{TAble 5-1: Empirical Aggregate Matching FunCtions By SourCes Of Flows And Broad OCCUPATIONAL GROUPS}

Dependent Variable: Hirings (per occupation and year) by sources

\begin{tabular}{|c|c|c|c|c|c|c|}
\hline \multirow[b]{2}{*}{ Log unemployed: $\ln U$} & \multicolumn{2}{|c|}{$\begin{array}{l}(14) \\
\text { total hirings } \\
\boldsymbol{m}_{\text {all }}\end{array}$} & \multicolumn{2}{|c|}{$\begin{array}{c}(15) \\
\text { hirings from non- } \\
\text { employment } \\
\boldsymbol{m}_{X}\end{array}$} & \multicolumn{2}{|c|}{$\begin{array}{c}(16) \\
\text { hirings from } \\
\text { unemployment } \\
\boldsymbol{m}_{\boldsymbol{U}}\end{array}$} \\
\hline & $0.446^{*}$ & $(0.018)$ & $0.456^{*}$ & $(0.017)$ & $0.538 *$ & $(0.029)$ \\
\hline Log registered vacancies: $\ln V$ & $0.379 *$ & $(0.017)$ & $0.379 *$ & $(0.016)$ & $0.337 *$ & $(0.024)$ \\
\hline Linear time trend & $-0.031 *$ & $(0.003)$ & $-0.034 *$ & $(0.003)$ & $-0.031 *$ & $(0.004)$ \\
\hline Group 1 (primary/agricultural) & -0.152 & $(0.082)$ & -0.046 & $(0.099)$ & 0.044 & $(0.149)$ \\
\hline Group 2 (industry/manufacturing) & $-0.126^{*}$ & $(0.021)$ & $-0.127 *$ & $(0.023)$ & $0.091 *$ & $(0.029)$ \\
\hline Group 3 (crafts) & $0.099 *$ & $(0.019)$ & $0.160 *$ & $(0.020)$ & $0.310 *$ & $(0.032)$ \\
\hline Group 4 (technical occupations) & $-0.204 *$ & $(0.055)$ & $-0.378^{*}$ & $(0.057)$ & $-0.635^{*}$ & $(0.082)$ \\
\hline Group 5 (services) & -0.040 & $(0.038)$ & -0.041 & $(0.037)$ & $-0.192 *$ & $(0.050)$ \\
\hline Group 6 (white collar/clerical) & $0.526^{*}$ & $(0.041)$ & $0.326 *$ & $(0.047)$ & -0.024 & $(0.046)$ \\
\hline Group 7 (social and cultural) & -0.067 & $(0.057)$ & -0.009 & $(0.061)$ & $-0.506^{*}$ & $(0.061)$ \\
\hline Group 8 (health) & $0.332 *$ & $(0.042)$ & $0.306^{*}$ & $(0.038)$ & $-0.393 *$ & $(0.082)$ \\
\hline Group 9 (low skilled) & -0.014 & $(0.060)$ & 0.008 & $(0.062)$ & $0.237 *$ & $(0.069)$ \\
\hline $\mathrm{R}^{2}$ & \multicolumn{2}{|c|}{0.878} & \multicolumn{2}{|c|}{0.855} & \multicolumn{2}{|c|}{0.747} \\
\hline Observations & \multicolumn{2}{|c|}{1311} & \multicolumn{2}{|c|}{1310} & \multicolumn{2}{|c|}{1298} \\
\hline $\mathrm{H}_{0}$ : constant returns to scale & \multicolumn{2}{|c|}{$\mathrm{F}(1,1299)=186.23$} & \multicolumn{2}{|c|}{$\mathrm{F}(1,1298)=134.91$} & \multicolumn{2}{|c|}{$\mathrm{F}(1,1286)=52.41$} \\
\hline \multicolumn{7}{|c|}{$\begin{array}{l}\text { Note: Robust standard errors are in parentheses. For a detailed description of the definition of occupational groups, refer to the data } \\
\text { appendix. Coefficients and standard errors are obtained using a 2-step procedure following Haisken-DeNew and Schmidt (1997). } \\
\text { The first step provides robust OLS-results with group } 1 \text { as reference group. On the second step, dummy coefficients are } \\
\text { renormalized as deviations weighted by group-size from a group-size weighted mean (where group size refers to the number of } \\
\text { occupations contained in a group) and standard errors are adjusted accordingly. The procedure therefore renders the results } \\
\text { independent from the choice of the reference group. }\end{array}$} \\
\hline
\end{tabular}




\section{TABle 5-2: Matching FunCtions Disaggregated By BroAd OCCUPATIONAL GrouP}

\begin{tabular}{|c|c|c|c|c|c|c|c|c|c|c|}
\hline & \multicolumn{10}{|c|}{ Dependent Variable: } \\
\hline & \multirow{3}{*}{\multicolumn{5}{|c|}{$\begin{array}{l}(17) \\
\text { total hirings } \\
\boldsymbol{m}_{\text {all }}\end{array}$}} & \multirow{3}{*}{\multicolumn{5}{|c|}{$\begin{array}{c}(18) \\
\text { hirings from non-employment } \\
\boldsymbol{m}_{\boldsymbol{X}}\end{array}$}} \\
\hline & & & & & & & & & & \\
\hline & & & & & & & & & & \\
\hline & $\alpha$ & $\beta$ & CRS & Obs. & $\mathrm{R}^{2}$ & $\alpha$ & $\beta$ & CRS & Obs. & $\mathrm{R}^{2}$ \\
\hline $\begin{array}{l}\text { Group } 1 \\
\text { (primary sector) }\end{array}$ & $\begin{array}{c}0.401 \\
(0.091)\end{array}$ & $\begin{array}{c}0.533 \\
(0.072)\end{array}$ & $\begin{array}{l}\mathrm{F}(1,76) \\
1.18\end{array}$ & 80 & 0.728 & $\begin{array}{c}0.388 \\
(0.118)\end{array}$ & $\begin{array}{c}0.614 \\
(0.087)\end{array}$ & $\begin{array}{l}\mathrm{F}(1,76) \\
0.00\end{array}$ & 80 & 0.675 \\
\hline $\begin{array}{l}\text { Group } 2 \\
\text { (industry/manufacturing) }\end{array}$ & $\begin{array}{c}0.372 \\
(0.025)\end{array}$ & $\begin{array}{c}0.359 \\
(0.027)\end{array}$ & $\begin{array}{l}\mathrm{F}(1,443) \\
209.38 * *\end{array}$ & 447 & 0.814 & $\begin{array}{c}0.345 \\
(0.023)\end{array}$ & $\begin{array}{c}0.379 \\
(0.022)\end{array}$ & $\begin{array}{l}\mathrm{F}(1,442) \\
166.91 * *\end{array}$ & 446 & 0.776 \\
\hline $\begin{array}{l}\text { Group } 3 \\
\text { (crafts) }\end{array}$ & $\begin{array}{c}0.594 \\
(0.018)\end{array}$ & $\begin{array}{c}0.442 \\
(0.015)\end{array}$ & $\begin{array}{l}\mathrm{F}(1,284) \\
4.44^{*}\end{array}$ & 288 & 0.948 & $\begin{array}{c}0.675 \\
(0.020)\end{array}$ & $\begin{array}{c}0.402 \\
(0.017)\end{array}$ & $\begin{array}{l}\mathrm{F}(1,284) \\
14.73 * *\end{array}$ & 288 & 0.937 \\
\hline $\begin{array}{l}\text { Group } 4 \\
\text { (technical occupations) }\end{array}$ & $\begin{array}{c}0.781 \\
(0.046)\end{array}$ & $\begin{array}{c}0.425 \\
(0.042)\end{array}$ & $\begin{array}{l}\mathrm{F}(1,60) \\
29.64 * *\end{array}$ & 64 & 0.930 & $\begin{array}{c}0.775 \\
(0.069)\end{array}$ & $\begin{array}{c}0.382 \\
(0.055)\end{array}$ & $\begin{array}{l}\mathrm{F}(1,60) \\
11.90^{* *}\end{array}$ & 64 & 0.901 \\
\hline $\begin{array}{l}\text { Group } 5 \\
\text { (services) }\end{array}$ & $\begin{array}{c}0.608 \\
(0.045)\end{array}$ & $\begin{array}{c}0.416 \\
(0.042)\end{array}$ & $\begin{array}{l}F(1,156) \\
0.96\end{array}$ & 160 & 0.929 & $\begin{array}{c}0.654 \\
(0.047)\end{array}$ & $\begin{array}{c}0.382 \\
(0.043)\end{array}$ & $\begin{array}{l}\mathrm{F}(1,156) \\
2.47\end{array}$ & 160 & 0.934 \\
\hline $\begin{array}{l}\text { Group } 6 \\
\text { (white collar/clerical) }\end{array}$ & $\begin{array}{c}0.420 \\
(0.060)\end{array}$ & $\begin{array}{c}0.336 \\
(0.059)\end{array}$ & $\begin{array}{l}\mathrm{F}(1,92) \\
90.00^{* *}\end{array}$ & 96 & 0.920 & $\begin{array}{c}0.534 \\
(0.071)\end{array}$ & $\begin{array}{c}0.270 \\
(0.068)\end{array}$ & $\begin{array}{l}\mathrm{F}(1,92) \\
46.85^{* *}\end{array}$ & 96 & 0.898 \\
\hline $\begin{array}{l}\text { Group } 7 \\
\text { (social and cultural) }\end{array}$ & $\begin{array}{c}0.211 \\
(0.134)\end{array}$ & $\begin{array}{c}0.412 \\
(0.099)\end{array}$ & $\begin{array}{l}\mathrm{F}(1,92) \\
65.60^{* *}\end{array}$ & 96 & 0.845 & $\begin{array}{c}0.319 \\
(0.142)\end{array}$ & $\begin{array}{c}0.331 \\
(0.106)\end{array}$ & $\begin{array}{l}\mathrm{F}(1,92) \\
54.33^{* *}\end{array}$ & 96 & 0.830 \\
\hline $\begin{array}{l}\text { Group } 8 \\
\text { (health) }\end{array}$ & $\begin{array}{c}0.593 \\
(0.050)\end{array}$ & $\begin{array}{c}0.343 \\
(0.051)\end{array}$ & $\begin{array}{l}\mathrm{F}(1,44) \\
2.84\end{array}$ & 48 & 0.912 & $\begin{array}{c}0.640 \\
(0.034)\end{array}$ & $\begin{array}{c}0.326 \\
(0.039)\end{array}$ & $\begin{array}{l}\mathrm{F}(1,44) \\
1.11\end{array}$ & 48 & 0.945 \\
\hline $\begin{array}{l}\text { Group } 9 \\
\text { (low skilled) }\end{array}$ & $\begin{array}{c}0.425 \\
(0.058)\end{array}$ & $\begin{array}{c}0.503 \\
(0.048)\end{array}$ & $\begin{array}{l}\mathrm{F}(1,28) \\
1.34\end{array}$ & 32 & 0.865 & $\begin{array}{c}0.382 \\
(0.058)\end{array}$ & $\begin{array}{c}0.399 \\
(0.047)\end{array}$ & $\begin{array}{l}\mathrm{F}(1,28) \\
12.99 * *\end{array}$ & 32 & 0.838 \\
\hline
\end{tabular}

Note: $\alpha$ is the estimated coefficient for $\ln U, \beta$ is the estimated coefficient for $\ln V$. All models are estimated including a constant and a linear time trend. Robust standard errors are in parentheses. Insignificant coefficients are set in italics. CRS: Contains the F-statistics for $\mathrm{H}_{0}$ : The matching function exhibits constant returns to scale. For a detailed description of the definition of occupational groups, refer to the data appendix.

$* \mathrm{H}_{0}$ : Constant returns to scale can be rejected on the $5 \%$-level.

$* * \mathrm{H}_{0}$ : Constant returns to scale can be rejected on the $1 \%$-level. 


\section{TABle 5-3: Matching Functions Disaggregated By BroAd OCCUPATIONAL GrouP}

\begin{tabular}{|c|c|c|c|c|c|c|c|c|c|c|}
\hline & \multicolumn{10}{|c|}{ Dependent Variable: } \\
\hline & \multirow{3}{*}{\multicolumn{5}{|c|}{$\begin{array}{c}(17) \\
\text { total hirings } \\
\boldsymbol{m}_{\text {all }}\end{array}$}} & \multirow{3}{*}{\multicolumn{5}{|c|}{$\begin{array}{c}(19) \\
\text { hirings from unemployment } \\
\boldsymbol{m}_{U}\end{array}$}} \\
\hline & & & & & & & & & & \\
\hline & & & & & & & & & & \\
\hline & $\alpha$ & $\beta$ & CRS & Obs. & $\mathrm{R}^{2}$ & $\alpha$ & $\beta$ & CRS & Obs. & $\mathrm{R}^{2}$ \\
\hline $\begin{array}{l}\text { Group } 1 \\
\text { (primary sector) }\end{array}$ & $\begin{array}{c}0.401 \\
(0.091)\end{array}$ & $\begin{array}{c}0.533 \\
(0.072)\end{array}$ & $\begin{array}{l}\mathrm{F}(1,76) \\
1.18\end{array}$ & 80 & 0.728 & $\begin{array}{c}0.605 \\
(0.219)\end{array}$ & $\begin{array}{c}0.542 \\
(0.136)\end{array}$ & $\begin{array}{l}\mathrm{F}(1,73) \\
1.54\end{array}$ & 77 & 0.483 \\
\hline $\begin{array}{l}\text { Group } 2 \\
\text { (industry/manufacturing) }\end{array}$ & $\begin{array}{c}0.372 \\
(0.025)\end{array}$ & $\begin{array}{c}0.359 \\
(0.027)\end{array}$ & $\begin{array}{l}\mathrm{F}(1,443) \\
209.38^{* *}\end{array}$ & 447 & 0.814 & $\begin{array}{c}0.285 \\
(0.039)\end{array}$ & $\begin{array}{c}0.374 \\
(0.036)\end{array}$ & $\begin{array}{l}\mathrm{F}(1,437) \\
141.40^{* *}\end{array}$ & 441 & 0.593 \\
\hline $\begin{array}{l}\text { Group } 3 \\
\text { (crafts) }\end{array}$ & $\begin{array}{c}0.594 \\
(0.018)\end{array}$ & $\begin{array}{c}0.442 \\
(0.015)\end{array}$ & $\begin{array}{l}\mathrm{F}(1,284) \\
4.44^{*}\end{array}$ & 288 & 0.948 & $\begin{array}{c}0.828 \\
(0.042)\end{array}$ & $\begin{array}{c}0.211 \\
(0.031)\end{array}$ & $\begin{array}{l}\mathrm{F}(1,284) \\
1.52\end{array}$ & 288 & 0.746 \\
\hline $\begin{array}{l}\text { Group } 4 \\
\text { (technical occupations) }\end{array}$ & $\begin{array}{c}0.781 \\
(0.046)\end{array}$ & $\begin{array}{c}0.425 \\
(0.042)\end{array}$ & $\begin{array}{l}\mathrm{F}(1,60) \\
29.64 * *\end{array}$ & 64 & 0.930 & $\begin{array}{c}1.257 \\
(0.090)\end{array}$ & $\begin{array}{c}0.161 \\
(0.067)\end{array}$ & $\begin{array}{l}\mathrm{F}(1,59) \\
27.46^{* *}\end{array}$ & 63 & 0.846 \\
\hline $\begin{array}{l}\text { Group } 5 \\
\text { (services) }\end{array}$ & $\begin{array}{l}0.608 \\
(0.045)\end{array}$ & $\begin{array}{c}0.416 \\
(0.042)\end{array}$ & $\begin{array}{l}\mathrm{F}(1,156) \\
0.96\end{array}$ & 160 & 0.929 & $\begin{array}{c}0.781 \\
(0.062)\end{array}$ & $\begin{array}{c}0.302 \\
(0.053)\end{array}$ & $\begin{array}{l}\mathrm{F}(1,154) \\
5.31^{*}\end{array}$ & 158 & 0.876 \\
\hline $\begin{array}{l}\text { Group } 6 \\
\text { (white collar/clerical) }\end{array}$ & $\begin{array}{c}0.420 \\
(0.060)\end{array}$ & $\begin{array}{c}0.336 \\
(0.059)\end{array}$ & $\begin{array}{l}\mathrm{F}(1,92) \\
90.00^{* *}\end{array}$ & 96 & 0.920 & $\begin{array}{c}0.678 \\
(0.077)\end{array}$ & $\begin{array}{c}0.154 \\
(0.087)\end{array}$ & $\begin{array}{l}\mathrm{F}(1,91) \\
20.20^{* *}\end{array}$ & 95 & 0.923 \\
\hline $\begin{array}{l}\text { Group } 7 \\
\text { (social and cultural) }\end{array}$ & $\begin{array}{c}0.211 \\
(0.134)\end{array}$ & $\begin{array}{c}0.412 \\
(0.099)\end{array}$ & $\begin{array}{l}\mathrm{F}(1,92) \\
65.60^{* *}\end{array}$ & 96 & 0.845 & $\begin{array}{c}0.434 \\
(0.138)\end{array}$ & $\begin{array}{c}0.423 \\
(0.106)\end{array}$ & $\begin{array}{l}\mathrm{F}(1,92) \\
9.78^{* *}\end{array}$ & 96 & 0.874 \\
\hline $\begin{array}{l}\text { Group } 8 \\
\text { (health) }\end{array}$ & $\begin{array}{c}0.593 \\
(0.050)\end{array}$ & $\begin{array}{c}0.343 \\
(0.051)\end{array}$ & $\begin{array}{l}\mathrm{F}(1,44) \\
2.84\end{array}$ & 48 & 0.912 & $\begin{array}{c}1.023 \\
(0.037)\end{array}$ & $\begin{array}{c}0.393 \\
(0.060)\end{array}$ & $\begin{array}{l}\mathrm{F}(1,44) \\
85.32 * *\end{array}$ & 48 & 0.958 \\
\hline $\begin{array}{l}\text { Group } 9 \\
\text { (low skilled) }\end{array}$ & $\begin{array}{c}0.425 \\
(0.058)\end{array}$ & $\begin{array}{c}0.503 \\
(0.048)\end{array}$ & $\begin{array}{l}\mathrm{F}(1,28) \\
1.34\end{array}$ & 32 & 0.865 & $\begin{array}{c}0.472 \\
(0.068)\end{array}$ & $\begin{array}{c}0.215 \\
(0.058)\end{array}$ & $\begin{array}{l}\mathrm{F}(1,28) \\
23.14 * *\end{array}$ & 32 & 0.780 \\
\hline
\end{tabular}

Note: $\alpha$ is the estimated coefficient for $\ln U, \beta$ is the estimated coefficient for $\ln V$. All models are estimated including a constant and a linear time trend. Robust standard errors are in parentheses. Insignificant coefficients are set in italics. CRS: Contains the F-statistics for $\mathrm{H}_{0}$ : The matching function exhibits constant returns to scale. For a detailed description of the definition of occupational groups, refer to the data appendix.

$* \mathrm{H}_{0}$ : Constant returns to scale can be rejected on the $5 \%$-level.

$* * \mathrm{H}_{0}$ : Constant returns to scale can be rejected on the $1 \%$-level. 
TABle 5-4: MATChing FunCtions FOR All Hirings DisAggregated By BroAd OCCUPATIONAL GROUP, UNCONSTRAINED AND CONSTRAINED TO CRS

\begin{tabular}{|c|c|c|c|c|c|c|c|c|}
\hline & \multicolumn{8}{|c|}{ Dependent Variable: } \\
\hline & \multicolumn{4}{|c|}{$\begin{array}{l}(17) \\
\text { total hirings } \\
\text { unconstrained } \\
\boldsymbol{m}_{\text {all }}\end{array}$} & \multicolumn{4}{|c|}{$\begin{array}{c}\left(17^{\prime}\right) \\
\text { total hirings } \\
\text { with constant returns to scale imposed } \\
\boldsymbol{m}_{\text {all }}\end{array}$} \\
\hline & $\alpha$ & $\beta$ & Obs. & $\mathrm{R}^{2}$ & $\alpha$ & $\beta$ & Obs. & $\operatorname{Root}(\mathrm{MSE})$ \\
\hline $\begin{array}{l}\text { Group } 1 \\
\text { (primary sector) }\end{array}$ & $\begin{array}{c}0.401 \\
(0.091)\end{array}$ & $\begin{array}{c}0.533 \\
(0.072)\end{array}$ & 80 & 0.728 & $\begin{array}{c}0.469 \\
(0.074)\end{array}$ & $\begin{array}{c}0.531 \\
(0.469)\end{array}$ & 80 & 0.691 \\
\hline $\begin{array}{l}\text { Group } 2 \\
\text { (industry/manufacturing) }\end{array}$ & $\begin{array}{c}0.372 \\
(0.025)\end{array}$ & $\begin{array}{c}0.359 \\
(0.027)\end{array}$ & 447 & 0.814 & $\begin{array}{c}0.416 \\
(0.023)\end{array}$ & $\begin{array}{c}0.584 \\
(0.023)\end{array}$ & 447 & 0.565 \\
\hline $\begin{array}{l}\text { Group } 3 \\
\text { (crafts) }\end{array}$ & $\begin{array}{c}0.594 \\
(0.018)\end{array}$ & $\begin{array}{c}0.442 \\
(0.015)\end{array}$ & 288 & 0.948 & $\begin{array}{c}0.567 \\
(0.012)\end{array}$ & $\begin{array}{c}0.433 \\
(0.012)\end{array}$ & 288 & 0.202 \\
\hline $\begin{array}{l}\text { Group } 4 \\
\text { (technical occupations) }\end{array}$ & $\begin{array}{c}0.781 \\
(0.046)\end{array}$ & $\begin{array}{c}0.425 \\
(0.042)\end{array}$ & 64 & 0.930 & $\begin{array}{c}0.572 \\
(0.050)\end{array}$ & $\begin{array}{c}0.428 \\
(0.050)\end{array}$ & 64 & 0.316 \\
\hline $\begin{array}{l}\text { Group } 5 \\
\text { (services) }\end{array}$ & $\begin{array}{c}0.608 \\
(0.045)\end{array}$ & $\begin{array}{c}0.416 \\
(0.042)\end{array}$ & 160 & 0.929 & $\begin{array}{c}0.584 \\
(0.043)\end{array}$ & $\begin{array}{c}0.416 \\
(0.043)\end{array}$ & 160 & 0.411 \\
\hline $\begin{array}{l}\text { Group } 6 \\
\text { (white collar/clerical) }\end{array}$ & $\begin{array}{c}0.420 \\
(0.060)\end{array}$ & $\begin{array}{c}0.336 \\
(0.059)\end{array}$ & 96 & 0.920 & $\begin{array}{c}0.604 \\
(0.095)\end{array}$ & $\begin{array}{c}0.396 \\
(0.095)\end{array}$ & 96 & 0.555 \\
\hline $\begin{array}{l}\text { Group } 7 \\
\text { (social and cultural) }\end{array}$ & $\begin{array}{c}0.211 \\
(0.134)\end{array}$ & $\begin{array}{c}0.412 \\
(0.099)\end{array}$ & 96 & 0.845 & $\begin{array}{l}1.066 \\
(0.102)\end{array}$ & $\begin{array}{l}-0.066 \\
(0.102)\end{array}$ & 96 & 0.698 \\
\hline $\begin{array}{l}\text { Group } 8 \\
\text { (health) }\end{array}$ & $\begin{array}{c}0.593 \\
(0.050)\end{array}$ & $\begin{array}{c}0.343 \\
(0.051)\end{array}$ & 48 & 0.912 & $\begin{array}{c}0.637 \\
(0.053)\end{array}$ & $\begin{array}{c}0.363 \\
(0.053)\end{array}$ & 48 & 0.268 \\
\hline $\begin{array}{l}\text { Group } 9 \\
\text { (low skilled) }\end{array}$ & $\begin{array}{c}0.425 \\
(0.058)\end{array}$ & $\begin{array}{c}0.503 \\
(0.048)\end{array}$ & 32 & 0.865 & $\begin{array}{c}0.457 \\
(0.049)\end{array}$ & $\begin{array}{c}0.543 \\
(0.049)\end{array}$ & 32 & 0.236 \\
\hline
\end{tabular}

Note: $\alpha$ is the estimated coefficient for $\ln U, \beta$ is the estimated coefficient for $\ln V$. All models are estimated including a linear time trend. For the unconstrained model robust standard errors, for the constrained model standard errors are in parentheses. Insignificant coefficients are set in italics. For a detailed description of the definition of occupational groups, refer to the data appendix. 


\section{TABLE 5-5: MATCHING FUNCTIONS FOR HIRINGS FROM NON-EMPLOYMENT, DiSAGGREGATED BY BROAD OCCUPATIONAL GROUP, UNCONSTRAINED AND CONSTRAINED TO CRS}

\begin{tabular}{|c|c|c|c|c|c|c|c|c|}
\hline & \multicolumn{8}{|c|}{ Dependent Variable: } \\
\hline & \multirow{3}{*}{\multicolumn{4}{|c|}{$\begin{array}{l}(18) \\
\text { hirings from non-employment, } \\
\text { unconstrained } \\
\boldsymbol{m}_{X}\end{array}$}} & \multirow{3}{*}{\multicolumn{4}{|c|}{$\begin{array}{c}\left(18^{\prime}\right) \\
\text { hirings from non-employment with constant } \\
\text { returns to scale imposed } \\
\boldsymbol{m}_{X}\end{array}$}} \\
\hline & & & & & & & & \\
\hline & & & & & & & & \\
\hline Group 1 & 0.388 & 0.614 & 80 & 0.675 & 0.386 & $\frac{\rho}{0.614}$ & 80 & 0.853 \\
\hline (primary sector) & $(0.118)$ & $(0.087)$ & & & $(0.092)$ & $(0.092)$ & & \\
\hline $\begin{array}{l}\text { Group } 2 \\
\text { (industrv/manufacturing) }\end{array}$ & 0.345 & 0.379 & 446 & 0.776 & 0.562 & 0.438 & 446 & 0.614 \\
\hline Group 3 & $\begin{array}{l}(0.025) \\
0.675\end{array}$ & 0.402 & 288 & 0.937 & 0.617 & 0.383 & 288 & 0.234 \\
\hline (crafts) & $(0.020)$ & $(0.017)$ & & & $(0.014)$ & $(0.014)$ & & \\
\hline $\begin{array}{l}\text { Group } 4 \\
\text { (technical occupations) }\end{array}$ & $\begin{array}{c}0.775 \\
(0.069)\end{array}$ & $\begin{array}{c}0.382 \\
(0.055)\end{array}$ & 64 & 0.901 & $\begin{array}{c}0.615 \\
(0.054)\end{array}$ & $\begin{array}{c}0.385 \\
(0.054)\end{array}$ & 64 & 0.340 \\
\hline Group 5 & 0.654 & 0.382 & 160 & 0.934 & 0.618 & 0.382 & 160 & 0.399 \\
\hline (services) & $(0.047)$ & $(0.043)$ & & & $(0.042)$ & $(0.042)$ & & \\
\hline Group 6 & 0.534 & 0.270 & 96 & 0.898 & $\begin{array}{c}0.678 \\
(0.098)\end{array}$ & $\begin{array}{c}0.322 \\
(0.098)\end{array}$ & 96 & 0.573 \\
\hline $\begin{array}{l}\text { (white collar/clerical) } \\
\text { Group } 7\end{array}$ & $\begin{array}{c}(0.071) \\
0.319\end{array}$ & $\begin{array}{c}(0.068) \\
0.331\end{array}$ & 96 & 0.830 & $\begin{array}{c}(0.098) \\
1.110\end{array}$ & $\begin{array}{l}(0.098) \\
-0.110\end{array}$ & 96 & 0.697 \\
\hline (social and cultural) & $(0.142)$ & $(0.106)$ & & & $(0.102)$ & $(0.102)$ & & \\
\hline Group 8 & 0.640 & 0.326 & 48 & 0.945 & 0.664 & 0.336 & 48 & 0.211 \\
\hline (health) & $(0.034)$ & $(0.039)$ & & & $(0.041)$ & $(0.041)$ & & \\
\hline Group 9 & 0.382 & 0.399 & 32 & 0.838 & 0.479 & 0.521 & 32 & 0.259 \\
\hline (low skilled) & $(0.058)$ & $(0.047)$ & & & $(0.054)$ & $(0.054)$ & & \\
\hline
\end{tabular}

Note: $\alpha$ is the estimated coefficient for $\ln U, \beta$ is the estimated coefficient for $\ln V$. All models are estimated including a constant and a linear time trend. For the unconstrained model robust standard errors, for the constrained model standard errors are in parentheses. Insignificant coefficients are set in italics. 
TABLe 6-1: Descriptive Statistics (Age Groups, Aggregate)

\begin{tabular}{|c|c|c|c|c|c|}
\hline & & $\begin{array}{c}\text { Total Shares } \\
\text { (Averages } \\
\text { 1980-1995) }\end{array}$ & $\begin{array}{c}\text { Age } \\
\text { Group } 1 \\
(16-25)\end{array}$ & $\begin{array}{c}\text { Age } \\
\text { Group } 2 \\
(25-50)\end{array}$ & $\begin{array}{c}\text { Age } \\
\text { Group } 3 \\
(50-65)\end{array}$ \\
\hline \multicolumn{5}{|l|}{ Relative group sizes: } & $18.49 \%$ \\
\hline employed & & $100 \%$ & $24.76 \%$ & $57.10 \%$ & $18.14 \%$ \\
\hline non-employed & & $100 \%$ & $22.71 \%$ & $53.78 \%$ & $23.51 \%$ \\
\hline \multicolumn{6}{|l|}{ Hirings: } \\
\hline total matchings: & $m_{\text {all }}$ & $100 \%$ & $\begin{array}{l}46.40 \% \\
(100 \%)\end{array}$ & $\begin{array}{l}46.25 \% \\
(100 \%)\end{array}$ & $\begin{array}{c}7.36 \% \\
(100 \%)\end{array}$ \\
\hline from employment: & $\boldsymbol{m}_{E}$ & $31.40 \%$ & $\begin{array}{c}38.58 \% \\
(26.11 \%)\end{array}$ & $\begin{array}{c}53.56 \% \\
(36.37 \%)\end{array}$ & $\begin{array}{c}7.87 \% \\
(33.57 \%)\end{array}$ \\
\hline from nonemployment: & $m_{X}$ & $68.60 \%$ & $\begin{array}{c}49.98 \% \\
(73.89 \%)\end{array}$ & $\begin{array}{c}42.90 \% \\
(63.63 \%)\end{array}$ & $\begin{array}{c}7.12 \% \\
(66.43 \%)\end{array}$ \\
\hline from unemployment: & $m_{U}$ & $23.04 \%$ & $\begin{array}{c}34.36 \% \\
(17.06 \%)\end{array}$ & $\begin{array}{c}54.50 \% \\
(27.15 \%)\end{array}$ & $\begin{array}{c}11.14 \% \\
(34.88 \%)\end{array}$ \\
\hline from out of labor force: & $m_{O L}$ & $45.56 \%$ & $\begin{array}{c}57.87 \% \\
(56.83 \%)\end{array}$ & $\begin{array}{c}37.03 \% \\
(36.48 \%)\end{array}$ & $\begin{array}{c}5.09 \% \\
(31.55 \%)\end{array}$ \\
\hline \multicolumn{6}{|c|}{$\begin{array}{l}\text { Note: All data are aggregated over all } 82 \text { occupations and averages over the period 1980-1995. Table entries for } \\
\text { hirings represent shares of the age group characteristics with respect to total shares (that is they add up to } \\
100 \% \text { horizontally). Entries in parentheses are shares of the respective flows with respect to the respective } \\
\text { age group (that is they add up to } 100 \% \text { vertically). Therefore, the share of a given flow of a given age } \\
\text { group with respect to total hirings can be calculated by multiplying the entry with the share of that flow } \\
\text { with respect to total hires (that is the first column value). }\end{array}$} \\
\hline
\end{tabular}


TAble 6-2: Empirical Aggregate Matching Functions By SourCes ANd Age Groups

Dependent Variable: All Hirings $\boldsymbol{m}_{\text {all }}$ and Hirings from Non-Employment $\boldsymbol{m}_{X}$ (per occupation and year) by Age Groups

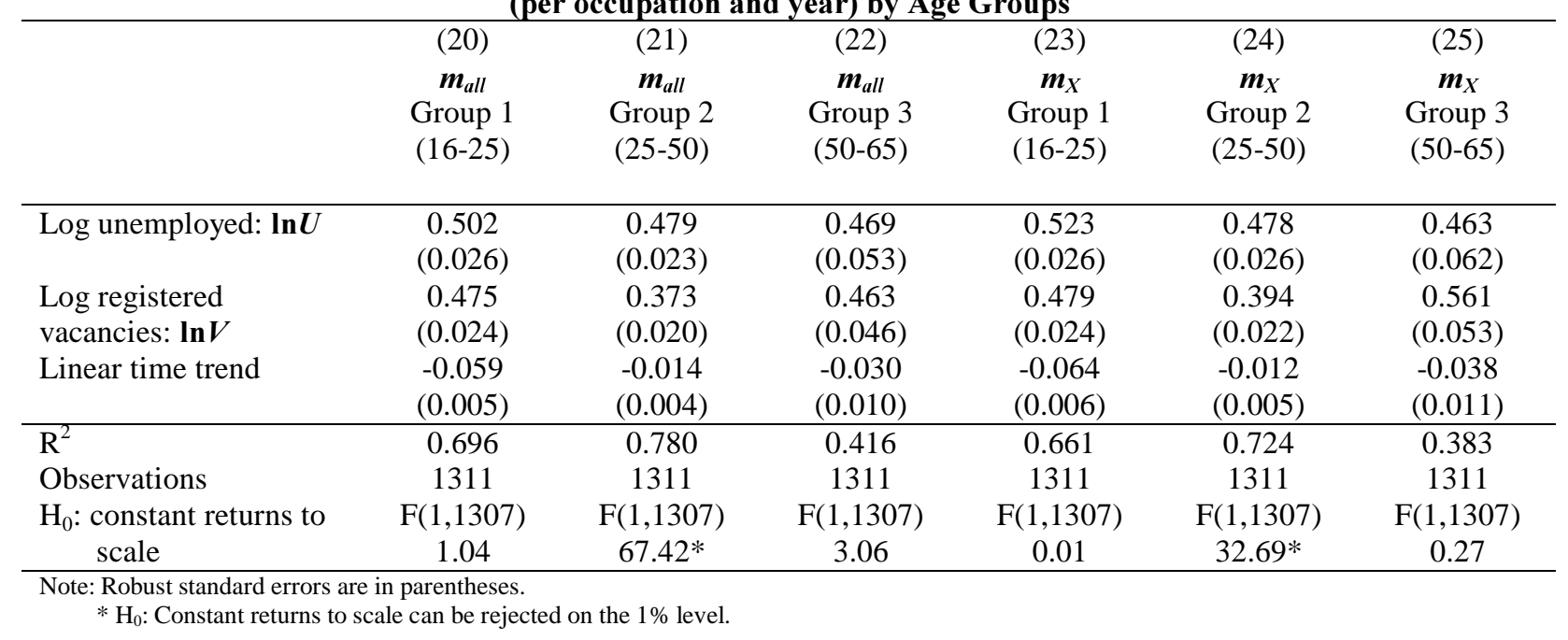




\section{TAble 6-3: Empirical Aggregate Matching FunCtions By Age Groups}

Dependent Variable: All hirings $m_{\text {all }}$ (per occupation and year) by age

\begin{tabular}{|c|c|c|c|c|c|c|}
\hline & \multicolumn{2}{|c|}{$\begin{array}{c}(26) \\
\text { Group } 1 \\
(15-25)\end{array}$} & \multicolumn{2}{|c|}{$\begin{array}{c}(27) \\
\text { Group } 2 \\
(25-50)\end{array}$} & \multicolumn{2}{|c|}{$\begin{array}{c}(28) \\
\text { Group } 3 \\
(50-65)\end{array}$} \\
\hline & \multicolumn{2}{|c|}{$m_{\text {all }}$} & \multicolumn{2}{|c|}{$\boldsymbol{m}_{\text {all }}$} & \multicolumn{2}{|c|}{$\boldsymbol{m}_{\text {all }}$} \\
\hline Log unemployed: $\ln U$ & $0.521 *$ & $(0.027)$ & $0.425^{*}$ & $(0.022)$ & $0.433 *$ & $(0.057)$ \\
\hline Log registered vacancies: $\ln V$ & $0.471 *$ & $(0.029)$ & $0.377^{*}$ & $(0.021)$ & $0.485^{*}$ & $(0.051)$ \\
\hline Linear time trend & $-0.059 *$ & $(0.005)$ & $-0.012 *$ & $(0.004)$ & $-0.030^{*}$ & $(0.010)$ \\
\hline Group 1 (primary/agricultural) & -0.197 & $(0.178)$ & $-0.548 *$ & $(0.102)$ & 0.020 & $(0.249)$ \\
\hline Group 2 (industry/manufacturing) & $0.159 *$ & $(0.041)$ & $-0.157 *$ & $(0.023)$ & -0.040 & $(0.070)$ \\
\hline Group 3 (crafts) & $0.328 *$ & $(0.027)$ & $-0.071 *$ & $(0.026)$ & -0.024 & $(0.073)$ \\
\hline Group 4 (technical occupations) & $-0.915 *$ & $(0.126)$ & $0.149 *$ & $(0.053)$ & $-0.354 *$ & $(0.133)$ \\
\hline Group 5 (services) & $-0.301 *$ & $(0.078)$ & 0.100 & $(0.040)$ & 0.083 & $(0.140)$ \\
\hline Group 6 (white collar/clerical) & 0.158 & $(0.097)$ & $0.761 *$ & $(0.044)$ & $0.677 *$ & $(0.088)$ \\
\hline Group 7 (social and cultural) & $-0.614 *$ & $(0.109)$ & $0.294 *$ & $(0.051)$ & -0.024 & $(0.155)$ \\
\hline Group 8 (health) & 0.068 & $(0.144)$ & 0.104 & $(0.135)$ & $-0.917 *$ & $(0.129)$ \\
\hline Group 9 (low skilled) & -0.090 & $(0.065)$ & 0.087 & $(0.079)$ & $0.445^{*}$ & $(0.094)$ \\
\hline $\mathrm{R}^{2}$ & \multicolumn{2}{|c|}{0.738} & \multicolumn{2}{|c|}{0.821} & \multicolumn{2}{|c|}{0.434} \\
\hline Observations & \multicolumn{2}{|c|}{1311} & \multicolumn{2}{|c|}{1311} & \multicolumn{2}{|c|}{1311} \\
\hline $\mathrm{H}_{0}$ : constant returns to scale & \multicolumn{2}{|c|}{$\mathrm{F}(1,1299)=0.10$} & \multicolumn{2}{|c|}{$\mathrm{F}(1,1299)=143.89 * *$} & \multicolumn{2}{|c|}{$\mathrm{F}(1,1299)=3.74$} \\
\hline \multicolumn{7}{|c|}{$\begin{array}{l}\text { Note: Robust standard errors are in parentheses. Coefficients without asterisk are significant at the 5\%-level. Italics indicate that the null } \\
\text { that the coefficient is zero cannot be rejected at the 5\%-level. For a detailed description of the definition of occupational groups, } \\
\text { refer to the data appendix. Coefficients and standard errors are obtained using a } 2 \text {-step procedure following Haisken-DeNew and } \\
\text { Schmidt (1997). The first step provides robust OLS-results with group } 1 \text { as reference group. On the second step, dummy } \\
\text { coefficients are renormalized as deviations weighted by group-size from a group-size weighted mean (where group size refers to the } \\
\text { number of occupations contained in a group) and standard errors are adjusted accordingly. The procedure therefore renders the } \\
\text { results independent from the choice of the reference group. }\end{array}$} \\
\hline
\end{tabular}




\section{TAble 6-4: Empirical Aggregate Matching Functions By Age Groups}

\section{Dependent Variable: Hirings from non-employment $m_{X}$ (per occupation and year) by age groups}

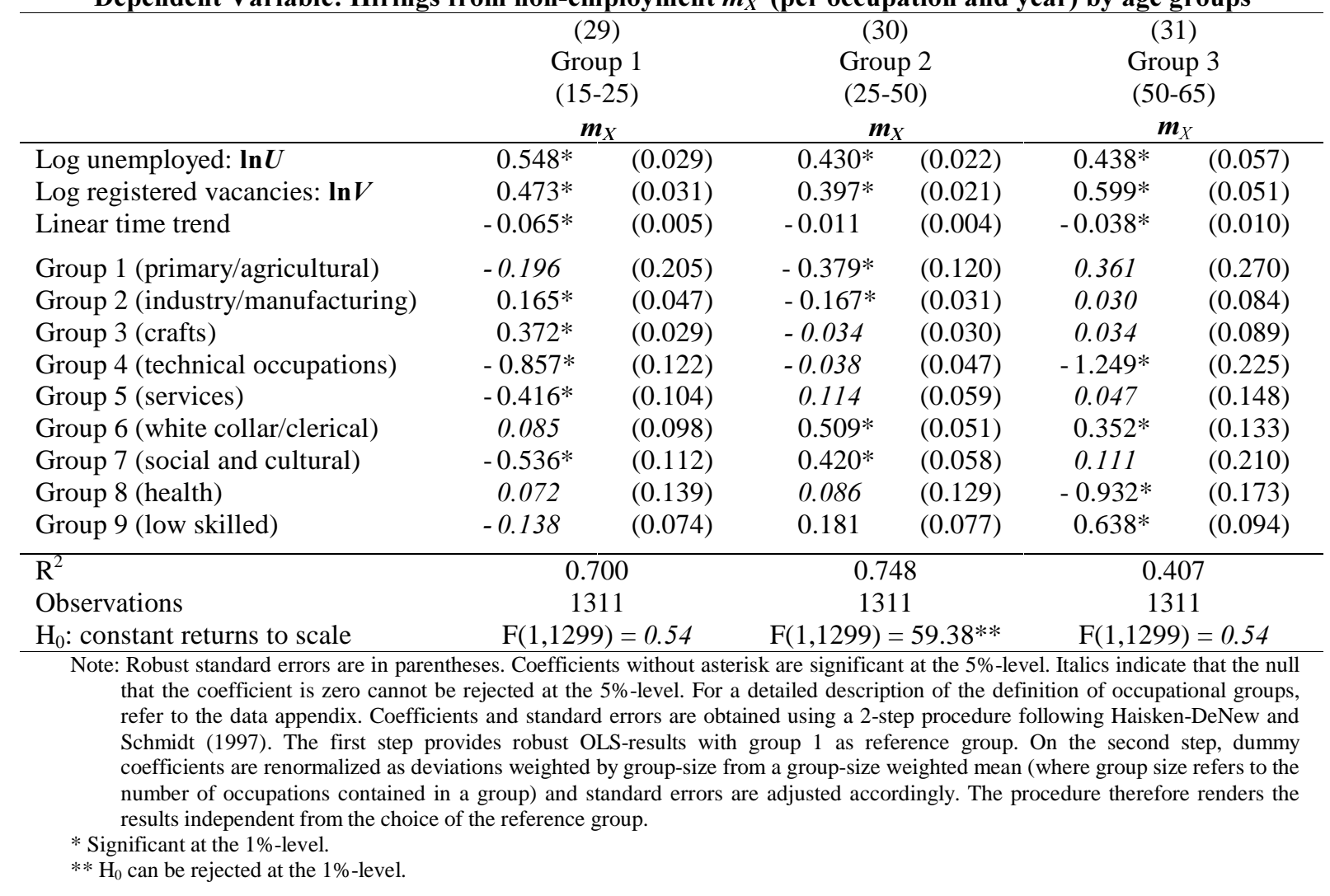




\section{TAble 6-5: Empirical Aggregate Matching FunCtions By Age Groups}

\section{Dependent Variable: Hirings from unemployment $m_{U}$ (per occupation and year) by age}

\begin{tabular}{|c|c|c|c|c|c|c|}
\hline \multirow{2}{*}{ Log unemployed: $\ln U$} & \multicolumn{2}{|c|}{$\begin{array}{c}(32) \\
\text { Group } 1 \\
(15-25)\end{array}$} & \multicolumn{2}{|c|}{$\begin{array}{c}(33) \\
\text { Group } 2 \\
(25-50)\end{array}$} & \multicolumn{2}{|c|}{$\begin{array}{c}(34) \\
\text { Group } 3 \\
(50-65)\end{array}$} \\
\hline & $0.738^{*}$ & $(0.054)$ & $0.587^{*}$ & $(0.048)$ & $0.503 *$ & $(0.081)$ \\
\hline Log registered vacancies: $\ln V$ & $0.500 *$ & $(0.049)$ & $0.440 *$ & $(0.039)$ & $0.721 *$ & $(0.067)$ \\
\hline Linear time trend & $-0.069 *$ & $(0.010)$ & $-0.024 *$ & $(0.007)$ & $-0.043 *$ & $(0.014)$ \\
\hline Group 1 (primary/agricultural) & 0.026 & $(0.216)$ & -0.536 & $(0.266)$ & 0.485 & $(0.335)$ \\
\hline Group 2 (industry/manufacturing) & $0.631 *$ & $(0.068)$ & $0.182 *$ & $(0.052)$ & $0.337 *$ & $(0.101)$ \\
\hline Group 3 (crafts) & $0.625^{*}$ & $(0.052)$ & $0.277^{*}$ & $(0.041)$ & $0.369 *$ & $(0.116)$ \\
\hline Group 4 (technical occupations) & $-2.070 *$ & $(0.314)$ & $-0.472 *$ & $(0.148)$ & $-1.573^{*}$ & $(0.235)$ \\
\hline Group 5 (services) & $-0.383^{*}$ & $(0.131)$ & $-0.438 *$ & $(0.119)$ & -0.140 & $(0.151)$ \\
\hline Group 6 (white collar/clerical) & $-0.352 *$ & $(0.126)$ & 0.132 & $(0.088)$ & -0.252 & $(0.204)$ \\
\hline Group 7 (social and cultural) & $-2.101 *$ & $(0.273)$ & -0.088 & $(0.080)$ & -0.396 & $(0.234)$ \\
\hline Group 8 (health) & $-0.940 *$ & $(0.352)$ & $-0.574 *$ & $(0.093)$ & $-2.938 *$ & $(0.345)$ \\
\hline Group 9 (low skilled) & $0.303 *$ & $(0.109)$ & 0.156 & $(0.091)$ & $0.942 *$ & $(0.128)$ \\
\hline $\mathrm{R}^{2}$ & \multicolumn{2}{|c|}{0.569} & \multicolumn{2}{|c|}{0.584} & \multicolumn{2}{|c|}{0.391} \\
\hline Observations & \multicolumn{2}{|c|}{1311} & \multicolumn{2}{|c|}{1311} & \multicolumn{2}{|c|}{1311} \\
\hline $\mathrm{H}_{0}$ : constant returns to scale & \multicolumn{2}{|c|}{$\mathrm{F}(1,1299)=31.28 * *$} & \multicolumn{2}{|c|}{$\mathrm{F}(1,1299)=0.53$} & \multicolumn{2}{|c|}{$\mathrm{F}(1,1299)=17.61 * *$} \\
\hline \multicolumn{7}{|c|}{$\begin{array}{l}\text { Note: Robust standard errors are in parentheses. Coefficients without asterisk are significant at the 5\%-level. Italics indicate that the null } \\
\text { that the coefficient is zero cannot be rejected at the } 5 \% \text {-level. For a detailed description of the definition of occupational groups, } \\
\text { refer to the data appendix. Coefficients and standard errors are obtained using a } 2 \text {-step procedure following Haisken-DeNew and } \\
\text { Schmidt (1997). The first step provides robust OLS-results with group } 1 \text { as reference group. On the second step, dummy } \\
\text { coefficients are renormalized as deviations weighted by group-size from a group-size weighted mean (where group size refers to the } \\
\text { number of occupations contained in a group) and standard errors are adjusted accordingly. The procedure therefore renders the } \\
\text { results independent from the choice of the reference group. } \\
* \text { Significant at the } 1 \% \text {-level. }\end{array}$} \\
\hline
\end{tabular}


TAble 7-1: Descriptive Statistics (Education Groups, Aggregate)

\begin{tabular}{|c|c|c|c|c|c|}
\hline & & $\begin{array}{c}\text { Total Shares } \\
\text { (Averages } \\
1980-1995 \text { ) }\end{array}$ & $\begin{array}{c}\text { Education } \\
\text { Group } 1 \\
\text { (low) }\end{array}$ & $\begin{array}{l}\text { Education } \\
\text { Group } 2 \\
\text { (middle) }\end{array}$ & $\begin{array}{c}\text { Education } \\
\text { Group } 3 \\
\text { (high) }\end{array}$ \\
\hline $\begin{array}{l}\text { Relative group sizes: } \\
\text { sample population }\end{array}$ & & $100 \%$ & $27.40 \%$ & $60.76 \%$ & $11.84 \%$ \\
\hline employed & & $100 \%$ & $26.98 \%$ & $61.66 \%$ & $11.36 \%$ \\
\hline non-employed & & $100 \%$ & $33.81 \%$ & $46.37 \%$ & $19.82 \%$ \\
\hline \multicolumn{6}{|l|}{ Hirings: } \\
\hline total matchings: & $m_{\text {all }}$ & $100 \%$ & $\begin{array}{l}34.40 \% \\
(100 \%)\end{array}$ & $\begin{array}{l}51.01 \% \\
(100 \%)\end{array}$ & $\begin{array}{l}14.51 \% \\
(100 \%)\end{array}$ \\
\hline from employment: & $m_{E}$ & $31.40 \%$ & $\begin{array}{c}20.55 \% \\
(18.76 \%)\end{array}$ & $\begin{array}{c}65.24 \% \\
(40.11 \%)\end{array}$ & $\begin{array}{l}14.21 \% \\
(30.74 \%)\end{array}$ \\
\hline from nonemployment: & $\boldsymbol{m}_{X}$ & $68.60 \%$ & $\begin{array}{c}40.74 \% \\
(81.24 \%)\end{array}$ & $\begin{array}{c}44.60 \% \\
(59.89 \%)\end{array}$ & $\begin{array}{l}14.65 \% \\
(69.26 \%)\end{array}$ \\
\hline from unemployment: & $m_{U}$ & $23.04 \%$ & $\begin{array}{c}26.43 \% \\
(17.70 \%)\end{array}$ & $\begin{array}{c}60.59 \% \\
(27.32 \%)\end{array}$ & $\begin{array}{l}12.98 \% \\
(20.61 \%)\end{array}$ \\
\hline from out of labor force: & $m_{O L}$ & $45.56 \%$ & $\begin{array}{c}47.98 \% \\
(63.54 \%)\end{array}$ & $\begin{array}{l}36.52 \% \\
(32.57 \%)\end{array}$ & $\begin{array}{l}15.50 \% \\
(48.65 \%)\end{array}$ \\
\hline
\end{tabular}

Note: All data are aggregated over all 82 occupations and averages over the period 1980-1995. Table entries are shares of the education group characteristics with respect to total shares (that is they add up to $100 \%$ horizontally). Entries in parentheses are shares of the respective flows with respect to the respective educational group (that is they add up to $100 \%$ vertically). Therefore, the share of a given flow of a given educational group with respect to total hirings can be calculated by multiplying the entry with the share of that flow with respect to total hires (that is the first column value). 


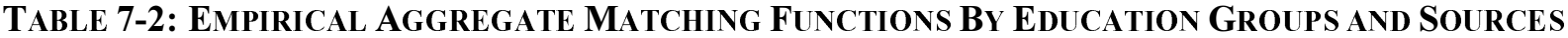

Dependent Variable: All Hirings $\boldsymbol{m}_{\text {all }}$ and Hirings from Non-Employment $\boldsymbol{m}_{X}$ by Education Groups and Sources

\begin{tabular}{|c|c|c|c|c|c|c|}
\hline & & & & & & \\
\hline & (35) & $(36)$ & (37) & (38) & (39) & $(40)$ \\
\hline & $\begin{array}{l}\boldsymbol{m}_{\text {all }} \\
\text { Group 1 } \\
\text { (low) }\end{array}$ & $\begin{array}{c}\boldsymbol{m}_{\text {all }} \\
\text { Group 2 } \\
\text { (middle) }\end{array}$ & $\begin{array}{c}\boldsymbol{m}_{\text {all }} \\
\text { Group } 3 \\
\text { (high) }\end{array}$ & $\begin{array}{c}\boldsymbol{m}_{X} \\
\text { Group 1 } \\
\text { (low) }\end{array}$ & $\begin{array}{c}\boldsymbol{m}_{X} \\
\text { Group } 2 \\
\text { (middle) }\end{array}$ & $\begin{array}{c}\boldsymbol{m}_{X} \\
\text { Group } 3 \\
\text { (high) }\end{array}$ \\
\hline \multirow[t]{2}{*}{ Log unemployed: $\ln U$} & 0.607 & 0.452 & 0.512 & 0.652 & 0.484 & 0.520 \\
\hline & $(0.048)$ & $(0.030)$ & $(0.043)$ & $(0.053)$ & $(0.032)$ & $(0.050)$ \\
\hline Log registered & 0.362 & 0.465 & 0.482 & 0.382 & 0.475 & 0.521 \\
\hline vacancies: $\ln V$ & $(0.038)$ & $(0.023)$ & $(0.036)$ & $(0.039)$ & $(0.024)$ & $(0.044)$ \\
\hline \multirow[t]{2}{*}{ Linear time trend } & -0.059 & -0.022 & -0.002 & -0.062 & -0.027 & -0.002 \\
\hline & $(0.010)$ & $(0.005)$ & $(0.008)$ & $(0.011)$ & $(0.006)$ & $(0.009)$ \\
\hline $\mathrm{R}^{2}$ & 0.405 & 0.783 & 0.528 & 0.409 & 0.701 & 0.499 \\
\hline Observations & 1311 & 1311 & 1311 & 1311 & 1311 & 1311 \\
\hline \multirow{2}{*}{$\begin{array}{l}\mathrm{H}_{0} \text { : constant returns to } \\
\text { scale }\end{array}$} & $\mathrm{F}(1,1307)$ & $\mathrm{F}(1,1307)$ & $F(1,1307)$ & $\mathrm{F}(1,1307)$ & $\mathrm{F}(1,1307)$ & $F(1,1307)$ \\
\hline & 0.76 & $17.49 *$ & 0.02 & 0.69 & 2.64 & 1.07 \\
\hline & & (s) & . & 5 & $\begin{array}{l}\text { on) have } \\
\text { finished }\end{array}$ & $\begin{array}{l}\text { inished high } \\
\text { lool (Abitur) } \\
\text { d university }\end{array}$ \\
\hline
\end{tabular}




\section{TABle 7-3: Empirical Aggregate Matching FunCtions By EduCation Group}

\section{Dependent Variable: All hirings $m_{\text {all }}$ (per occupation and year) by education}

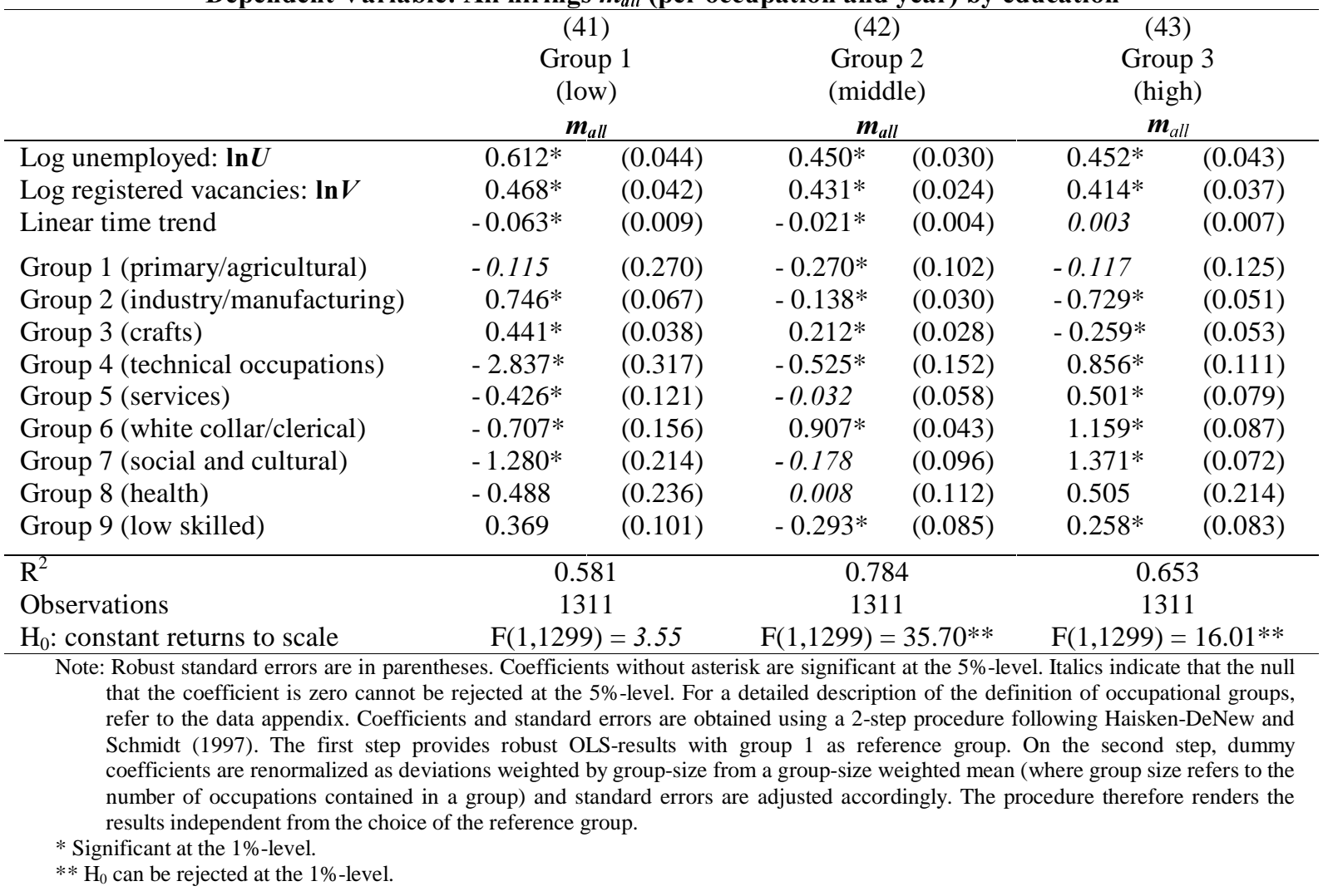




\section{Table 7-4: Empirical Aggregate Matching Functions By EduCation Group}

\section{Dependent Variable: Hirings from non-employment $m_{X}$ (per occupation and year) by education}

\begin{tabular}{|c|c|c|c|c|c|c|}
\hline \multirow{3}{*}{ Log unemployed: $\ln U$} & \multicolumn{2}{|c|}{$\begin{array}{c}(44) \\
\text { Group } 1 \\
(\text { low) }\end{array}$} & \multicolumn{2}{|c|}{$\begin{array}{c}(45) \\
\text { Group } 2 \\
\text { (middle) }\end{array}$} & \multicolumn{2}{|c|}{$\begin{array}{c}(46) \\
\text { Group } 3 \\
\text { (high ) }\end{array}$} \\
\hline & \multicolumn{2}{|c|}{$\boldsymbol{m}_{X}$} & \multicolumn{2}{|c|}{$\boldsymbol{m}_{X}$} & \multicolumn{2}{|c|}{$\boldsymbol{m}_{X}$} \\
\hline & $0.671 *$ & $(0.048)$ & $0.490^{*}$ & $(0.033)$ & $0.456^{*}$ & $(0.050)$ \\
\hline Log registered vacancies: $\ln V$ & $0.483 *$ & $(0.042)$ & $0.440 *$ & $(0.027)$ & $0.454 *$ & $(0.044)$ \\
\hline Linear time trend & $-0.066^{*}$ & $(0.009)$ & $-0.026^{*}$ & $(0.006)$ & 0.003 & $(0.008)$ \\
\hline Group 1 (primary/agricultural) & -0.043 & $(0.280)$ & -0.153 & $(0.158)$ & -0.055 & $(0.161)$ \\
\hline Group 2 (industry/manufacturing) & $0.746^{*}$ & $(0.070)$ & $-0.136 *$ & $(0.036)$ & $-0.758 *$ & $(0.059)$ \\
\hline Group 3 (crafts) & $0.510 *$ & $(0.040)$ & $0.258 *$ & $(0.030)$ & $-0.251 *$ & $(0.064)$ \\
\hline Group 4 (technical occupations) & $-2.879 *$ & $(0.330)$ & $-0.717 *$ & $(0.173)$ & $0.731 *$ & $(0.106)$ \\
\hline Group 5 (services) & $-0.505^{*}$ & $(0.128)$ & -0.027 & $(0.056)$ & $0.563 *$ & $(0.086)$ \\
\hline Group 6 (white collar/clerical) & $-0.954^{*}$ & $(0.187)$ & $0.705^{*}$ & $(0.050)$ & $1.018 *$ & $(0.093)$ \\
\hline Group 7 (social and cultural) & $-1.137 *$ & $(0.217)$ & -0.094 & $(0.104)$ & $1.522 *$ & $(0.083)$ \\
\hline Group 8 (health) & -0.417 & $(0.231)$ & 0.006 & $(0.099)$ & 0.495 & $(0.208)$ \\
\hline Group 9 (low skilled) & 0.253 & $(0.119)$ & $-0.311 *$ & $(0.082)$ & $0.366^{*}$ & $(0.082)$ \\
\hline $\mathrm{R}^{2}$ & \multicolumn{2}{|c|}{0.573} & \multicolumn{2}{|c|}{0.732} & \multicolumn{2}{|c|}{0.610} \\
\hline Observations & \multicolumn{2}{|c|}{1311} & \multicolumn{2}{|c|}{1311} & \multicolumn{2}{|c|}{1311} \\
\hline $\mathrm{H}_{0}$ : constant returns to scale & \multicolumn{2}{|c|}{$\mathrm{F}(1,1299)=10.72 * *$} & \multicolumn{2}{|c|}{$\mathrm{F}(1,1299)=7.60 * *$} & \multicolumn{2}{|c|}{$\mathrm{F}(1,1299)=6.46^{* *}$} \\
\hline \multicolumn{7}{|c|}{$\begin{array}{l}\text { Note: Robust standard errors are in parentheses. Coefficients without asterisk are significant at the } 5 \% \text {-level. Italics indicate that the null } \\
\text { that the coefficient is zero cannot be rejected at the } 5 \% \text {-level. For a detailed description of the definition of occupational groups, } \\
\text { refer to the data appendix. Coefficients and standard errors are obtained using a } 2 \text {-step procedure following Haisken-DeNew and } \\
\text { Schmidt (1997). The first step provides robust OLS-results with group } 1 \text { as reference group. On the second step, dummy } \\
\text { coefficients are renormalized as deviations weighted by group-size from a group-size weighted mean (where group size refers to the } \\
\text { number of occupations contained in a group) and standard errors are adjusted accordingly. The procedure therefore renders the } \\
\text { results independent from the choice of the reference group. }\end{array}$} \\
\hline
\end{tabular}




\section{TABle 7-5: Empirical Aggregate Matching Functions By EduCation Group}

\section{Dependent Variable: Hirings from unemployment $m_{U}$ (per occupation and year) by education}

\begin{tabular}{|c|c|c|c|c|c|c|}
\hline \multirow{2}{*}{$\begin{array}{l}\text { Log unemployed: } \ln U \\
\end{array}$} & \multicolumn{2}{|c|}{$\begin{array}{c}(47) \\
\text { Group } 1 \\
(\text { low })\end{array}$} & \multicolumn{2}{|c|}{$\begin{array}{c}(48) \\
\text { Group } 2 \\
\text { (middle) }\end{array}$} & \multicolumn{2}{|c|}{$\begin{array}{c}\text { (49) } \\
\text { Group } 3 \\
\text { (high) }\end{array}$} \\
\hline & $0.738^{*}$ & $(0.069)$ & $0.585^{*}$ & $(0.055)$ & $0.733^{*}$ & $(0.069)$ \\
\hline Log registered vacancies: $\ln V$ & $0.454 *$ & $(0.062)$ & $0.534 *$ & $(0.050)$ & $0.459 *$ & $(0.061)$ \\
\hline Linear time trend & $-0.062 *$ & $(0.012)$ & $-0.044 *$ & $(0.009)$ & 0.002 & $(0.011)$ \\
\hline Group 1 (primary/agricultural) & 0.645 & $(0.288)$ & -0.385 & $(0.255)$ & 0.035 & $(0.259)$ \\
\hline Group 2 (industry/manufacturing) & $1.299 *$ & $(0.080)$ & $0.228 *$ & $(0.059)$ & $-0.483 *$ & $(0.093)$ \\
\hline Group 3 (crafts) & $0.665 *$ & $(0.076)$ & $0.536^{*}$ & $(0.046)$ & 0.060 & $(0.089)$ \\
\hline Group 4 (technical occupations) & $-3.889 *$ & $(0.304)$ & $-1.336^{*}$ & $(0.289)$ & $0.456^{*}$ & $(0.169)$ \\
\hline Group 5 (services) & $-0.761 *$ & $(0.167)$ & $-0.289 *$ & $(0.110)$ & 0.165 & $(0.140)$ \\
\hline Group 6 (white collar/clerical) & $-1.540 *$ & $(0.178)$ & $0.334 *$ & $(0.080)$ & $0.562 *$ & $(0.152)$ \\
\hline Group 7 (social and cultural) & $-2.651 *$ & $(0.306)$ & $-0.803^{*}$ & $(0.205)$ & $0.900 *$ & $(0.133)$ \\
\hline Group 8 (health) & $-1.920 *$ & $(0.326)$ & $-0.871 *$ & $(0.302)$ & -0.282 & $(0.283)$ \\
\hline Group 9 (low skilled) & $1.257 *$ & $(0.137)$ & -0.225 & $(0.102)$ & $0.445^{*}$ & $(0.098)$ \\
\hline $\mathrm{R}^{2}$ & \multicolumn{2}{|c|}{0.525} & \multicolumn{2}{|c|}{0.561} & \multicolumn{2}{|c|}{0.491} \\
\hline Observations & \multicolumn{2}{|c|}{1311} & \multicolumn{2}{|c|}{1311} & \multicolumn{2}{|c|}{1311} \\
\hline $\mathrm{H}_{0}$ : constant returns to scale & \multicolumn{2}{|c|}{$\mathrm{F}(1,1299)=14.33 * *$} & \multicolumn{2}{|c|}{$\mathrm{F}(1,1299)=9.38 * *$} & \multicolumn{2}{|c|}{$\mathrm{F}(1,1299)=17.67 * *$} \\
\hline \multicolumn{7}{|c|}{$\begin{array}{l}\text { Note: Robust standard errors are in parentheses. Coefficients without asterisk are significant at the 5\%-level. Italics indicate that the null } \\
\text { that the coefficient is zero cannot be rejected at the 5\%-level. For a detailed description of the definition of occupational groups, } \\
\text { refer to the data appendix. Coefficients and standard errors are obtained using a 2-step procedure following Haisken-DeNew and } \\
\text { Schmidt (1997). The first step provides robust OLS-results with group } 1 \text { as reference group. On the second step, dummy } \\
\text { coefficients are renormalized as deviations weighted by group-size from a group-size weighted mean (where group size refers to the } \\
\text { number of occupations contained in a group) and standard errors are adjusted accordingly. The procedure therefore renders the } \\
\text { results independent from the choice of the reference group. }\end{array}$} \\
\hline $\mathrm{H}_{0}$ can be rejected at the $1 \%$-level. & & & & & & \\
\hline
\end{tabular}


Table A 4-2-1: Empirical Aggregate Matching Functions

Dependent Variable: Total Hirings (per occupation and year) $\boldsymbol{m}_{\text {all }}$

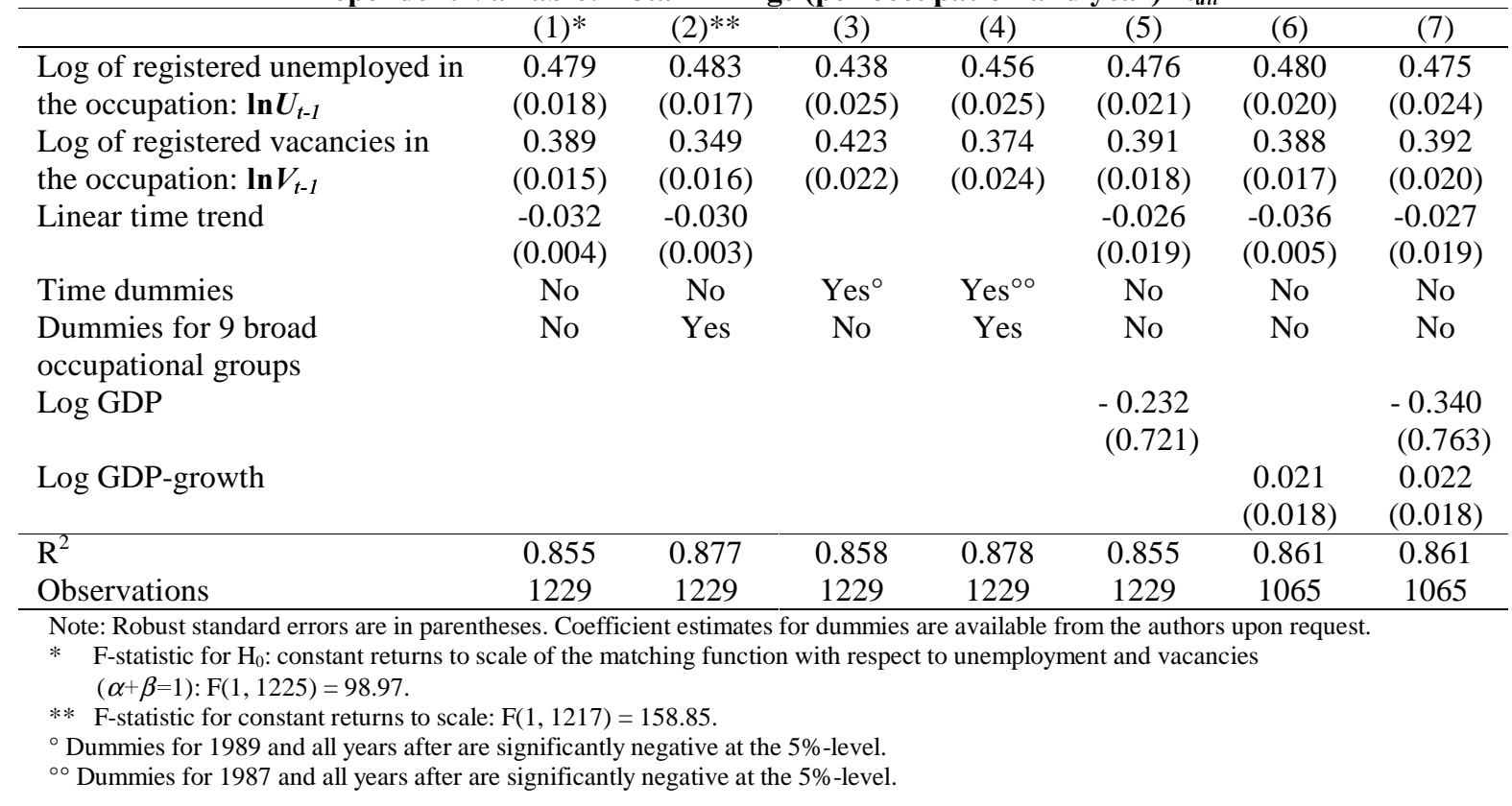




\section{Table A 4-2-2: EMpirical Aggregate Matching FunCtions}

\section{Dependent Variable: Total Hirings (per occupation and year) $\boldsymbol{m}_{\text {all }}$}

\begin{tabular}{|c|c|c|c|c|c|c|c|}
\hline & $(1)^{*}$ & $(2) * *$ & (3) & (4) & (5) & (6) & (7) \\
\hline Log of registered unemployed in & 0.449 & 0.520 & 0.432 & 0.455 & 0.507 & 0.507 & 0.499 \\
\hline the occupation: $\ln U_{t-2}$ & $(0.023)$ & $(0.018)$ & $(0.024)$ & $(0.024)$ & $(0.019)$ & $(0.021)$ & $(0.022)$ \\
\hline Log of registered vacancies in & 0.419 & 0.322 & 0.434 & 0.379 & 0.373 & 0.373 & 0.380 \\
\hline the occupation: $\ln V_{t-2}$ & $(0.019)$ & $(0.016)$ & $(0.021)$ & $(0.023)$ & $(0.015)$ & $(0.017)$ & $(0.018)$ \\
\hline Linear time trend & -0.013 & -0.032 & & & -0.019 & -0.037 & -0.001 \\
\hline & $(0.004)$ & $(0.004)$ & & & $(0.019)$ & $(0.005)$ & $(0.027)$ \\
\hline Time dummies & No & No & $\mathrm{Yes}^{\circ}$ & $\mathrm{Yes}^{\circ \circ}$ & No & No & No \\
\hline $\begin{array}{l}\text { Dummies for } 9 \text { broad } \\
\text { occupational groups }\end{array}$ & No & Yes & No & Yes & No & No & No \\
\hline Log GDP & & & & & $\begin{array}{l}-0.571 \\
(0.712)\end{array}$ & & $\begin{array}{c}-1.428 \\
(0.989)\end{array}$ \\
\hline Log GDP-growth & & & & & & $\begin{array}{c}0.014 \\
(0.029)\end{array}$ & $\begin{array}{c}0.054 \\
(0.040)\end{array}$ \\
\hline $\mathrm{R}^{2}$ & 0.853 & 0.875 & 0.857 & 0.878 & 0.852 & 0.862 & 0.862 \\
\hline Observations & 1147 & 1147 & 1147 & 1147 & 1147 & 983 & 983 \\
\hline \multicolumn{8}{|c|}{$\begin{array}{l}\text { Note: Robust standard errors are in parentheses. Coefficient estimates for dummies are available from the authors upon request. } \\
* \quad \text { F-statistic for } \mathrm{H}_{0} \text { : constant returns to scale of the matching function with respect to unemployment and vacancies } \\
(\alpha+\beta=1): \mathrm{F}(1,1143)=89.23 \text {. } \\
* * \quad \text { F-statistic for constant returns to scale: } \mathrm{F}(1,1135)=131.65 \text {. }\end{array}$} \\
\hline
\end{tabular}

\section{Table A4-2-3: Empirical Aggregate Matching Functions WITH IMPOSED CONSTANT RETURNS TO SCALE}

\section{Dependent Variable: Total Hirings (per occupation and year) $\boldsymbol{m}_{\text {all }}$}

\begin{tabular}{|c|c|c|c|c|c|c|c|}
\hline & $(1)$ & (2) & (3) & (4) & $(5)$ & (6) & (7) \\
\hline $\begin{array}{l}\text { Log of registered unemployed in } \\
\text { the occupation: } \ln U\end{array}$ & $\begin{array}{c}0.587 \\
(0.013)\end{array}$ & $\begin{array}{c}0.598 \\
(0.014)\end{array}$ & $\begin{array}{c}0.608 \\
(0.016)\end{array}$ & $\begin{array}{c}0.635 \\
(0.018)\end{array}$ & $\begin{array}{c}0.611 \\
(0.015)\end{array}$ & $\begin{array}{c}0.581 \\
(0.015)\end{array}$ & $\begin{array}{c}0.608 \\
(0.016)\end{array}$ \\
\hline $\begin{array}{l}\text { Log of registered vacancies in } \\
\text { the occupation: } \ln V\end{array}$ & $\begin{array}{c}0.413 \\
(0.013)\end{array}$ & $\begin{array}{c}0.402 \\
(0.014)\end{array}$ & $\begin{array}{c}0.392 \\
(0.016)\end{array}$ & $\begin{array}{c}0.365 \\
(0.018)\end{array}$ & $\begin{array}{c}0.389 \\
(0.015)\end{array}$ & $\begin{array}{c}0.419 \\
(0.015)\end{array}$ & $\begin{array}{c}0.392 \\
(0.016)\end{array}$ \\
\hline Linear time trend & $\begin{array}{l}-0.037 \\
(0.003)\end{array}$ & $\begin{array}{l}-0.037 \\
(0.003)\end{array}$ & & & $\begin{array}{l}-0.091 \\
(0.016)\end{array}$ & $\begin{array}{l}-0.078 \\
(0.016)\end{array}$ & $\begin{array}{l}-0.090 \\
(0.016)\end{array}$ \\
\hline Time dummies & No & No & Yes* & Yes* & No & No & No \\
\hline $\begin{array}{l}\text { Dummies for } 9 \text { broad } \\
\text { occupational groups }\end{array}$ & No & Yes & No & Yes & No & No & No \\
\hline Log GDP & & & & & $\begin{array}{c}2.207 \\
(0.630)\end{array}$ & & $\begin{array}{c}2.210 \\
(0.631)\end{array}$ \\
\hline Log GDP-growth & & & & & & $\begin{array}{l}-0.078 \\
(0.016)\end{array}$ & $\begin{array}{c}0.002 \\
(0.017)\end{array}$ \\
\hline Root(MSE) & 0.528 & 0.506 & 0.527 & 0.503 & 0.526 & 0.538 & 0.516 \\
\hline Observations & 1311 & 1311 & 1311 & 1311 & 1311 & 1147 & 1147 \\
\hline
\end{tabular}

Note: Standard errors are in parentheses. Coefficient estimates for dummies are available from the authors upon request.

* All dummies are significantly negative. 
TAble A4-3-1: Empirical Aggregate Matching Functions By SOURCes Of Flows

Dependent Variable: Hirings (per occupation and year) by sources

\begin{tabular}{|c|c|c|c|c|c|c|}
\hline & $\begin{array}{l}\left(8^{\prime}\right) \\
\text { total }\end{array}$ & $\begin{array}{c}\left(9^{\prime}\right) \\
\text { from non- } \\
\text { employment }\end{array}$ & $\begin{array}{c}\left(10^{\prime}\right) \\
\text { from } \\
\text { employment }\end{array}$ & $\begin{array}{c}\left(11^{\prime}\right) \\
\text { from un- } \\
\text { employment }\end{array}$ & $\begin{array}{l}\left(12^{\prime}\right) \\
\text { from out of } \\
\text { labor force }\end{array}$ & $\begin{array}{c}\left(13^{\prime}\right) \\
\text { from } \\
\text { registered } \\
\text { vacancies } \\
\boldsymbol{m}_{\boldsymbol{R}}^{*}\end{array}$ \\
\hline Lagged Log & 0.479 & 0.470 & 0.515 & 0.529 & 0.462 & 0.682 \\
\hline unemployed: $\ln \boldsymbol{U}_{t-1}$ & $(0.018)$ & $(0.019)$ & $(0.023)$ & $(0.031)$ & $(0.018)$ & $(0.041)$ \\
\hline Lagged Log registered & 0.389 & 0.400 & 0.381 & 0.342 & 0.438 & 0.266 \\
\hline vacancies: $\ln V_{t-1}$ & $(0.015)$ & $(0.015)$ & $(0.020)$ & $(0.024)$ & $(0.016)$ & $(0.037)$ \\
\hline \multirow[t]{2}{*}{ Linear time trend } & -0.032 & -0.039 & -0.013 & -0.042 & -0.032 & -0.009 \\
\hline & $(0.004)$ & $(0.004)$ & $(0.004)$ & $(0.005)$ & $(0.004)$ & $(0.008)$ \\
\hline $\mathrm{R}^{2}$ & 0.855 & 0.835 & 0.815 & 0.709 & 0.833 & 0.618 \\
\hline Observations & 1229 & 1228 & 1226 & 1217 & 1226 & 600 \\
\hline \multirow{3}{*}{$\begin{array}{l}\mathrm{H}_{0} \text { : constant returns to } \\
\text { scale }\end{array}$} & $\mathrm{F}(1$, & $\mathrm{F}(1,1224)$ & $\mathrm{F}(1,1222)$ & $\mathrm{F}(1,1213)$ & $\mathrm{F}(1,1304)$ & $\mathrm{F}(1,596)$ \\
\hline & 1225) & 79.86 & 46.62 & 47.36 & 53.83 & 3.18 \\
\hline & 98.97 & & & & & \\
\hline
\end{tabular}

Note: Standard errors are in parentheses.

* In contrast to flows from pools of job seekers, data of flows from registered vacancies are only available for a broader classification of 40 occupational groups.

Table A4-3-2: Empirical Aggregate Matching Functions By SourCes Of Flows

Dependent Variable: Hirings (per occupation and year) by sources

\begin{tabular}{|c|c|c|c|c|c|c|}
\hline & $\begin{array}{l}\left(8^{\prime \prime}\right) \\
\text { total }\end{array}$ & $\begin{array}{c}\left(9^{\prime \prime}\right) \\
\text { from non- } \\
\text { employment }\end{array}$ & $\begin{array}{c}\left(10{ }^{\prime}\right) \\
\text { from } \\
\text { employment }\end{array}$ & $\begin{array}{c}\left(11^{\prime \prime}\right) \\
\text { from un- } \\
\text { employment }\end{array}$ & $\begin{array}{c}\left(12^{\prime \prime}\right) \\
\text { from out of } \\
\text { labor force } \\
\boldsymbol{m}_{O L}\end{array}$ & $\begin{array}{c}\left(13^{\prime \prime}\right) \\
\text { from } \\
\text { registered } \\
\text { vacancies } \\
\boldsymbol{m}_{\boldsymbol{R}}{ }^{*}\end{array}$ \\
\hline Lagged Log & 0.510 & 0.482 & 0.596 & 0.521 & 0.490 & 0.731 \\
\hline unemployed: $\ln \boldsymbol{U}_{t-2}$ & $(0.018)$ & $(0.020)$ & $(0.022)$ & $(0.033)$ & $(0.016)$ & $(0.043)$ \\
\hline Lagged Log registered & 0.370 & 0.395 & 0.321 & 0.356 & 0.418 & 0.227 \\
\hline vacancies: $\ln V_{t-2}$ & $(0.014)$ & $(0.016)$ & $(0.017)$ & $(0.026)$ & $(0.016)$ & $(0.040)$ \\
\hline \multirow[t]{2}{*}{ Linear time trend } & -0.034 & -0.044 & -0.008 & -0.051 & -0.034 & -0.011 \\
\hline & $(0.004)$ & $(0.004)$ & $(0.005)$ & $(0.006)$ & $(0.005)$ & $(0.009)$ \\
\hline $\mathrm{R}^{2}$ & 0.851 & 0.832 & 0.817 & 0.767 & 0.828 & 0.617 \\
\hline Observations & 1147 & 1146 & 1144 & 1135 & 1144 & 560 \\
\hline $\mathrm{H}_{0}$ : constant returns to & $\mathrm{F}(1,1143)$ & $\mathrm{F}(1,1142)$ & $\mathrm{F}(1,1140)$ & $\mathrm{F}(1,1131)$ & $\mathrm{F}(1,1140)$ & $\mathrm{F}(1,556)$ \\
\hline scale & 75.52 & 68.46 & 28.29 & 40.21 & 33.20 & 1.85 \\
\hline
\end{tabular}




\section{TAble A4-3-3: EMPIRICAl Aggregate Matching FunCtions By SourCes Of Flows WITH IMPOSED CONSTANT RETURNS TO SCALE}

Dependent Variable: Hirings (per occupation and year) by sources

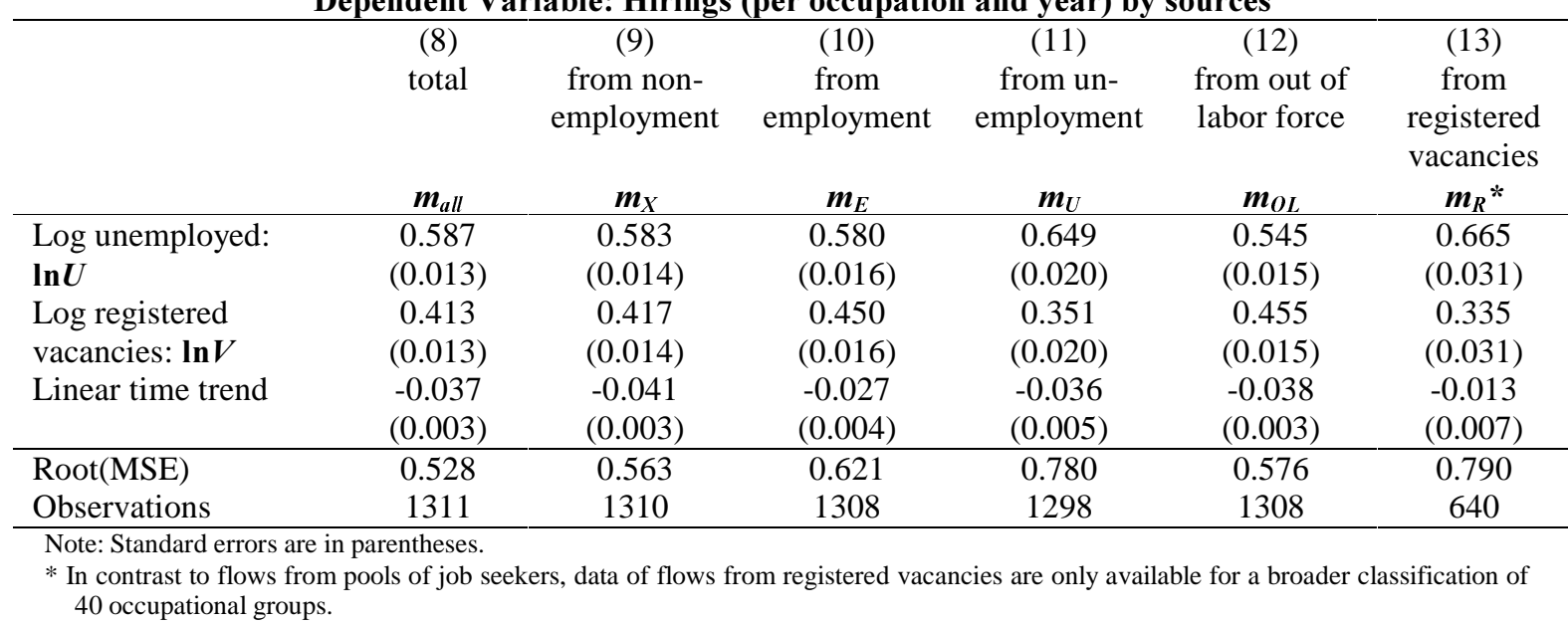

\section{Table A4-3-4: Empirical Aggregate Matching FunCtions By Sources of Flows,

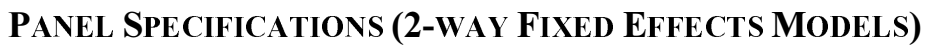

Dependent Variable: Hirings (per occupation and year) by sources

\begin{tabular}{|c|c|c|c|c|c|c|}
\hline & $\begin{array}{l}(8) \\
\text { total }\end{array}$ & $\begin{array}{c}(9) \\
\text { from non- } \\
\text { employment } \\
\boldsymbol{m}_{X}\end{array}$ & $\begin{array}{c}\text { (10) } \\
\text { from } \\
\text { employment } \\
\boldsymbol{m}_{E}\end{array}$ & $\begin{array}{c}(11) \\
\text { from un- } \\
\text { employment } \\
\boldsymbol{m}_{U}\end{array}$ & $\begin{array}{l}(12) \\
\text { from out of } \\
\text { labor force } \\
\boldsymbol{m}_{O L}\end{array}$ & $\begin{array}{c}(13) \\
\text { from } \\
\text { registered } \\
\text { vacancies } \\
\boldsymbol{m}_{\boldsymbol{R}}{ }^{*}\end{array}$ \\
\hline $\begin{array}{l}\text { Log unemployed: } \\
\ln U\end{array}$ & $\begin{array}{c}0.459 \\
(0.020)\end{array}$ & $\begin{array}{c}0.407 \\
(0.022)\end{array}$ & $\begin{array}{c}0.575 \\
(0.021)\end{array}$ & $\begin{array}{c}0.407 \\
(0.031)\end{array}$ & $\begin{array}{c}0.444 \\
(0.022)\end{array}$ & \\
\hline $\begin{array}{l}\text { Log registered } \\
\text { vacancies: } \ln V \\
\text { Fixed Effect: Time }\end{array}$ & $\begin{array}{l}0.369 \\
(0.017) \\
\text { Yes** }\end{array}$ & $\begin{array}{l}0.424 \\
(0.018) \\
\text { Yes*** }\end{array}$ & $\begin{array}{l}0.271 \\
(0.018) \\
\text { Yes** }\end{array}$ & $\begin{array}{c}0.449 \\
(0.026) \\
\text { Yes }\end{array}$ & $\begin{array}{l}0.405 \\
(0.018) \\
\text { Yes** }\end{array}$ & \\
\hline $\begin{array}{l}\text { Fixed Effect: Broad } \\
\text { Occupation }\end{array}$ & Yes & Yes & Yes & Yes & Yes & \\
\hline $\begin{array}{l}\mathrm{R}^{2} \\
\mathrm{R}^{2} \text { within } \\
\mathrm{R}^{2} \text { between } \\
\text { Observations } \\
\mathrm{H}_{0}: \text { constant returns } \\
\quad \text { to scale }\end{array}$ & $\begin{array}{c}0.859 \\
0.835 \\
0.893 \\
1311 \\
\mathrm{~F}(1,1285) \\
257.04\end{array}$ & $\begin{array}{c}0.844 \\
0.810 \\
0.901 \\
1310 \\
\mathrm{~F}(1,1284) \\
203.69\end{array}$ & $\begin{array}{c}0.824 \\
0.822 \\
0.786 \\
1308 \\
\mathrm{~F}(1,1282) \\
180.47\end{array}$ & $\begin{array}{c}0.720 \\
0.703 \\
0.740 \\
1298 \\
\mathrm{~F}(1,1272) \\
74.21\end{array}$ & $\begin{array}{c}0.840 \\
0.817 \\
0.839 \\
1308 \\
\mathrm{~F}(1,1282) \\
163.46\end{array}$ & \\
\hline $\begin{array}{l}\text { Note: Robust standard err } \\
\text { * In contrast to flows fro } \\
40 \text { occupational group } \\
\text { the other specification } \\
\text { ** Time effects negative } \\
\text { *** Time effects negative }\end{array}$ & $\begin{array}{l}\text { re in parenth } \\
\text { ols of job see } \\
\text { ce these grou } \\
\text { refrain from } \\
\text { icant. } \\
\text { significant ol }\end{array}$ & $\begin{array}{l}\text { data of flows } \\
\text { nnot be direct } \\
\text { ating this spec }\end{array}$ & $\begin{array}{l}\text { registered va } \\
\text { igned into the } \\
\text { on. }\end{array}$ & $\begin{array}{l}\text { S are only av } \\
1 \text { occupation }\end{array}$ & $\begin{array}{l}\text { for a broad } \\
\text { ps used for }\end{array}$ & $\begin{array}{l}\text { ification of } \\
d \text { effects in }\end{array}$ \\
\hline
\end{tabular}




\section{Table AA4-2: EMPIRICAl Aggregate Matching FunCtions (AdJusted Stocks)}

Dependent Variable: Total Hirings (per occupation and year) $\boldsymbol{m}_{\text {all }}$

\begin{tabular}{|c|c|c|c|c|c|c|c|}
\hline & (1) & (2) & (3) & (4) & (5) & (6) & (7) \\
\hline Log of registered unemployed in & 0.436 & 0.444 & 0.446 & 0.459 & 0.442 & 0.432 & 0.440 \\
\hline the occupation: $\ln U$ & $(0.024)$ & $(0.024)$ & $(0.025)$ & $(0.025)$ & $(0.024)$ & $(0.025)$ & $(0.025)$ \\
\hline Log of registered vacancies in & 0.419 & 0.382 & 0.411 & 0.369 & 0.414 & 0.424 & 0.418 \\
\hline the occupation: $\ln V$ & $(0.021)$ & $(0.023)$ & $(0.022)$ & $(0.024)$ & $(0.021)$ & $(0.023)$ & $(0.023)$ \\
\hline Linear time trend & -0.015 & -0.014 & & & -0.053 & -0.018 & -0.057 \\
\hline & $(0.003)$ & $(0.003)$ & & & $(0.013)$ & $(0.004)$ & $(0.013)$ \\
\hline Time dummies & No & No & Yes* & Yes* & No & No & No \\
\hline $\begin{array}{l}\text { Dummies for } 9 \text { broad } \\
\text { occupational groups }\end{array}$ & No & Yes & No & Yes & No & No & No \\
\hline Log GDP & & & & & $\begin{array}{c}1.571 \\
(0.524)\end{array}$ & & $\begin{array}{r}1.589 \\
(0.527)\end{array}$ \\
\hline Log GDP-growth & & & & & & $\begin{array}{c}0.016 \\
(0.016)\end{array}$ & $\begin{array}{r}0.017 \\
(0.016)\end{array}$ \\
\hline $\mathrm{R}^{2}$ & 0.858 & 0.878 & 0.860 & 0.879 & 0.859 & 0.863 & 0.864 \\
\hline Observations & 1311 & 1311 & 1311 & 1311 & 1311 & 1147 & 1147 \\
\hline
\end{tabular}

\section{Table AA 4-3: Empirical Aggregate Matching FunCtions By Sources of Flows (ADJUSTED STOCKS)}

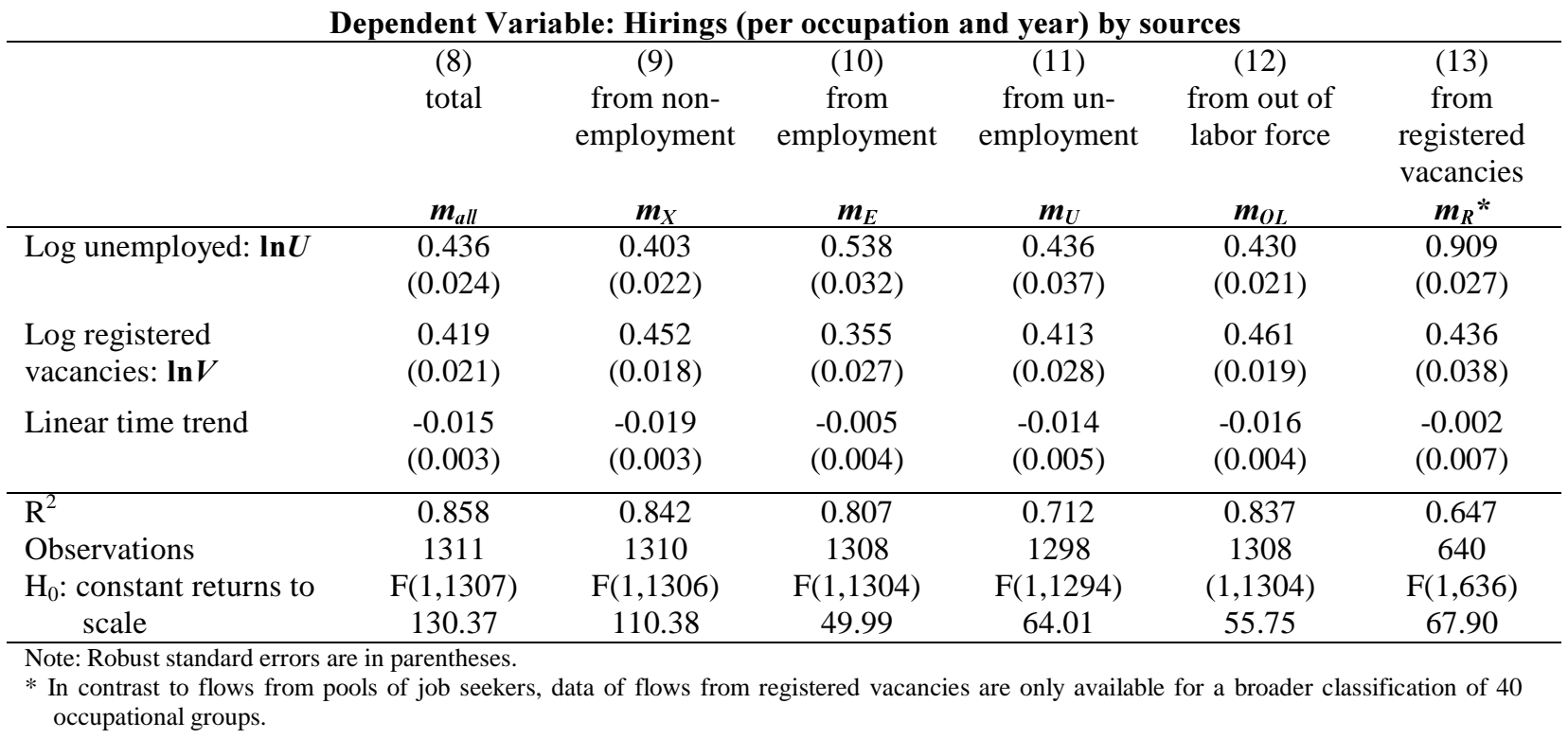




\section{Table A6-2-1: Empirical Aggregate Matching FunCtions By Age Groups and Sources ESTIMATED AS SEEMINGLY UNRELATED REGRESSIONS (SURE)}

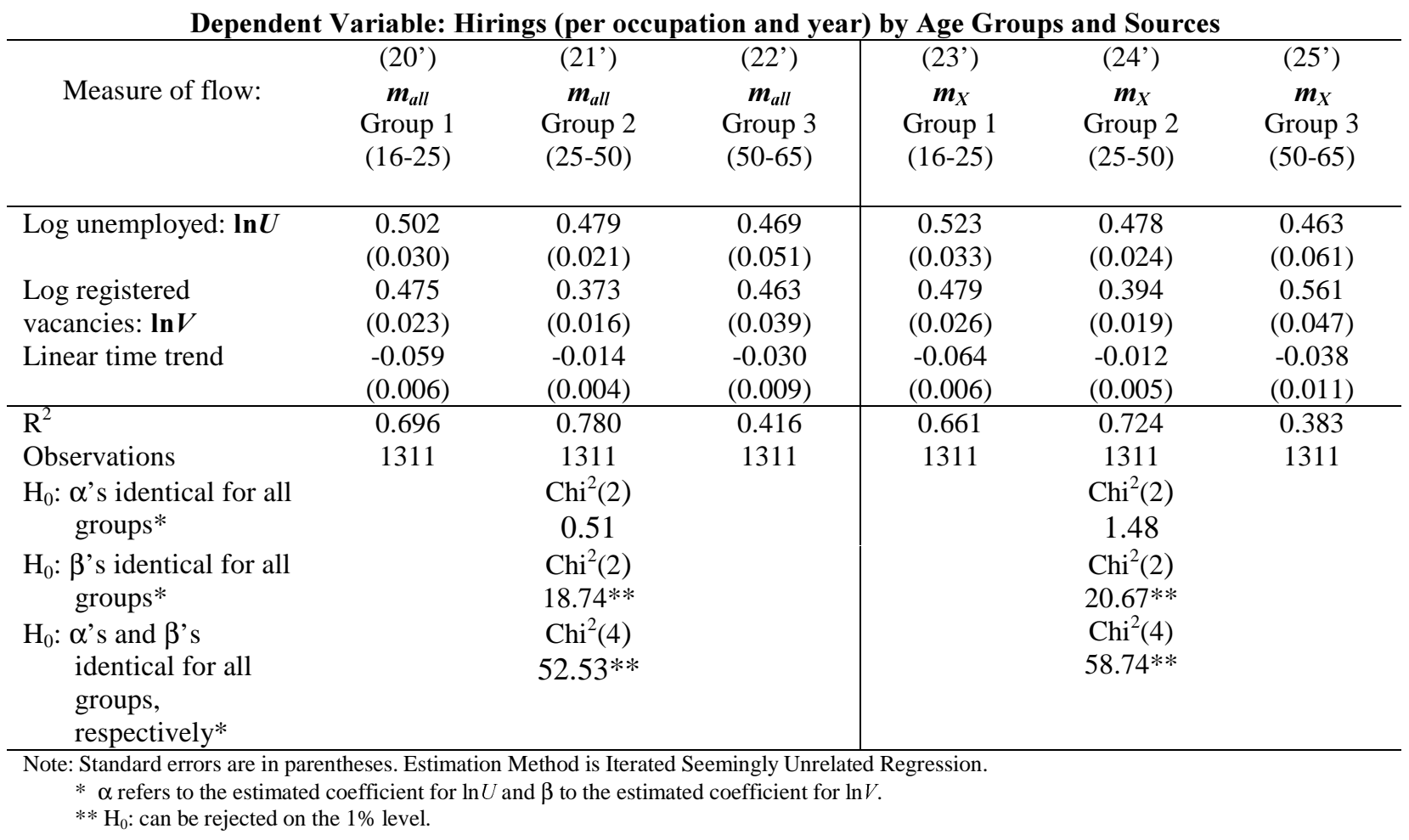




\section{Table A6-2-2: Empirical Aggregate Matching Functions By Age Groups and Sources ESTIMATED AS SEEMINGLY UNRELATED REGRESSIONS (SURE)}

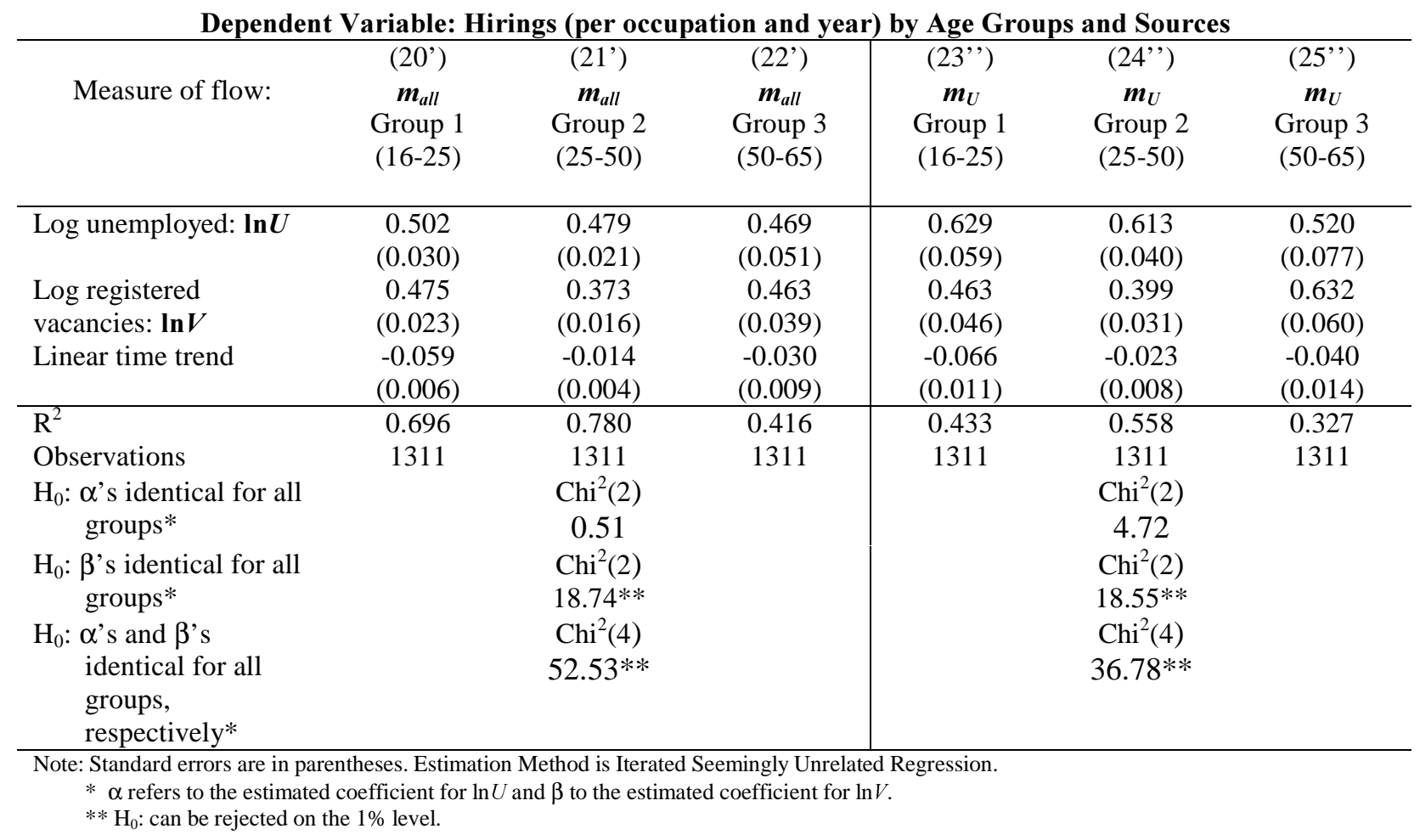




\section{Table A7-2-1: Empirical Aggregate Matching FunCtions By Education Groups And SOURCES ESTIMATED AS SEEMINGLY UNRELATED REGRESSIONS (SURE)}

\begin{tabular}{|c|c|c|c|c|c|c|}
\hline Measure of flow: & $\begin{array}{c}(18) \\
\boldsymbol{m}_{\text {all }} \\
\text { Group 1 } \\
\text { (Low) }\end{array}$ & $\begin{array}{c}(19) \\
\boldsymbol{m}_{\text {all }} \\
\text { Group } 2 \\
\text { (Middle) }\end{array}$ & $\begin{array}{c}(20) \\
\boldsymbol{m}_{\text {all }} \\
\text { Group } 3 \\
\text { (High) }\end{array}$ & $\begin{array}{c}(21) \\
\boldsymbol{m}_{X} \\
\text { Group 1 } \\
\text { (Low) }\end{array}$ & $\begin{array}{c}(22) \\
\boldsymbol{m}_{\boldsymbol{X}} \\
\text { Group } 2 \\
\text { (Middle) }\end{array}$ & $\begin{array}{c}(23) \\
\boldsymbol{m}_{\boldsymbol{X}} \\
\text { Group } 3 \\
\text { (High) }\end{array}$ \\
\hline Log unemployed: $\ln U$ & $\begin{array}{c}0.607 \\
(0.052)\end{array}$ & $\begin{array}{c}0.452 \\
(0.025)\end{array}$ & $\begin{array}{c}0.512 \\
(0.043)\end{array}$ & $\begin{array}{c}0.653 \\
(0.055)\end{array}$ & $\begin{array}{c}0.484 \\
(0.029)\end{array}$ & $\begin{array}{c}0.520 \\
(0.048)\end{array}$ \\
\hline $\begin{array}{l}\text { Log registered } \\
\text { vacancies: } \ln V \\
\text { Linear time trend }\end{array}$ & $\begin{array}{l}0.362 \\
(0.041) \\
-0.059 \\
(0.010) \\
\end{array}$ & $\begin{array}{l}0.465 \\
(0.019) \\
-0.022 \\
(0.005)\end{array}$ & $\begin{array}{l}0.482 \\
(0.034) \\
-0.002 \\
(0.008) \\
\end{array}$ & $\begin{array}{c}0.382 \\
(0.043) \\
-0.062 \\
(0.010)\end{array}$ & $\begin{array}{l}0.475 \\
(0.022) \\
-0.027 \\
(0.005) \\
\end{array}$ & $\begin{array}{c}0.521 \\
(0.038) \\
-0.002 \\
(0.009) \\
\end{array}$ \\
\hline 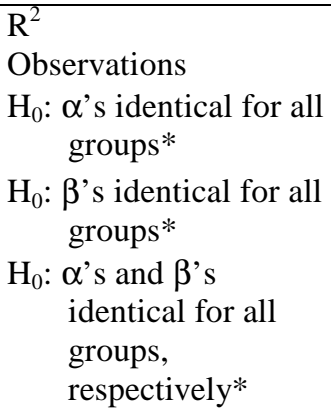 & $\begin{array}{c}0.404 \\
1311\end{array}$ & $\begin{array}{c}0.743 \\
1311 \\
\mathrm{Chi}^{2}(2) \\
15.98 * * \\
\mathrm{Chi}^{2}(2) \\
8.24 * * \\
\mathrm{Chi}^{2}(4) \\
20.37 * *\end{array}$ & $\begin{array}{c}0.528 \\
1311\end{array}$ & $\begin{array}{c}0.409 \\
1311\end{array}$ & $\begin{array}{c}0.701 \\
1311 \\
\mathrm{Chi}^{2}(2) \\
13.87 * * \\
\mathrm{Chi}^{2}(2) \\
6.06^{* *} \\
\mathrm{Chi}^{2}(4) \\
20.60^{* *}\end{array}$ & $\begin{array}{c}0.499 \\
1311\end{array}$ \\
\hline
\end{tabular}




\section{Table A7-2-2: Empirical Aggregate Matching FunCtions By Education Groups And SOURCES ESTIMATED AS SEEMINGLY UNRELATED REGRESSIONS (SURE)}

\begin{tabular}{|c|c|c|c|c|c|c|}
\hline Measure of flow: & $\begin{array}{c}(18) \\
\boldsymbol{m}_{\text {all }} \\
\text { Group 1 } \\
(\text { Low })\end{array}$ & $\begin{array}{c}(19) \\
\boldsymbol{m}_{\text {all }} \\
\text { Group } 2 \\
\text { (Middle) }\end{array}$ & $\begin{array}{c}(20) \\
\boldsymbol{m}_{\text {all }} \\
\text { Group } 3 \\
\text { (High) }\end{array}$ & $\begin{array}{c}(21) \\
\boldsymbol{m}_{U} \\
\text { Group 1 } \\
\text { (Low) }\end{array}$ & $\begin{array}{c}(22) \\
\boldsymbol{m}_{\boldsymbol{U}} \\
\text { Group } 2 \\
\text { (Middle) }\end{array}$ & $\begin{array}{c}(23) \\
\boldsymbol{m}_{\boldsymbol{U}} \\
\text { Group } 3 \\
\text { (High) }\end{array}$ \\
\hline $\begin{array}{l}\text { Log unemployed: } \ln U \\
\text { Log registered } \\
\text { vacancies: } \ln V \\
\text { Linear time trend }\end{array}$ & $\begin{array}{c}0.607 \\
(0.052) \\
0.362 \\
(0.041) \\
-0.059 \\
(0.010) \\
\end{array}$ & $\begin{array}{c}0.452 \\
(0.025) \\
0.465 \\
(0.019) \\
-0.022 \\
(0.005) \\
\end{array}$ & $\begin{array}{c}0.512 \\
(0.043) \\
0.482 \\
(0.034) \\
-0.002 \\
(0.008) \\
\end{array}$ & $\begin{array}{c}0.685 \\
(0.078) \\
0.291 \\
(0.061) \\
-0.053 \\
(0.015) \\
\end{array}$ & $\begin{array}{c}0.577 \\
(0.050) \\
0.520 \\
(0.039) \\
-0.043 \\
(0.009) \\
\end{array}$ & $\begin{array}{c}0.762 \\
(0.062) \\
0.511 \\
(0.048) \\
-0.001 \\
(0.012) \\
\end{array}$ \\
\hline 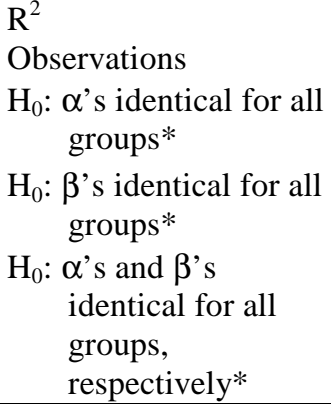 & $\begin{array}{c}0.404 \\
1311\end{array}$ & $\begin{array}{c}0.743 \\
1311 \\
\mathrm{Chi}^{2}(2) \\
15.98 * * \\
\mathrm{Chi}^{2}(2) \\
8.24 * * \\
\mathrm{Chi}^{2}(4) \\
20.37 * *\end{array}$ & $\begin{array}{c}0.528 \\
1311\end{array}$ & $\begin{array}{c}0.230 \\
1311\end{array}$ & $\begin{array}{c}0.504 \\
1311 \\
\mathrm{Chi}^{2}(2) \\
7.54 * * \\
\mathrm{Chi}^{2}(2) \\
17.02 * * \\
\operatorname{Chi}^{2}(4) \\
38.13 * *\end{array}$ & $\begin{array}{c}0.466 \\
1311\end{array}$ \\
\hline
\end{tabular}


Figure A1: Employment Levels of Broad Occupational Groups in Data Set

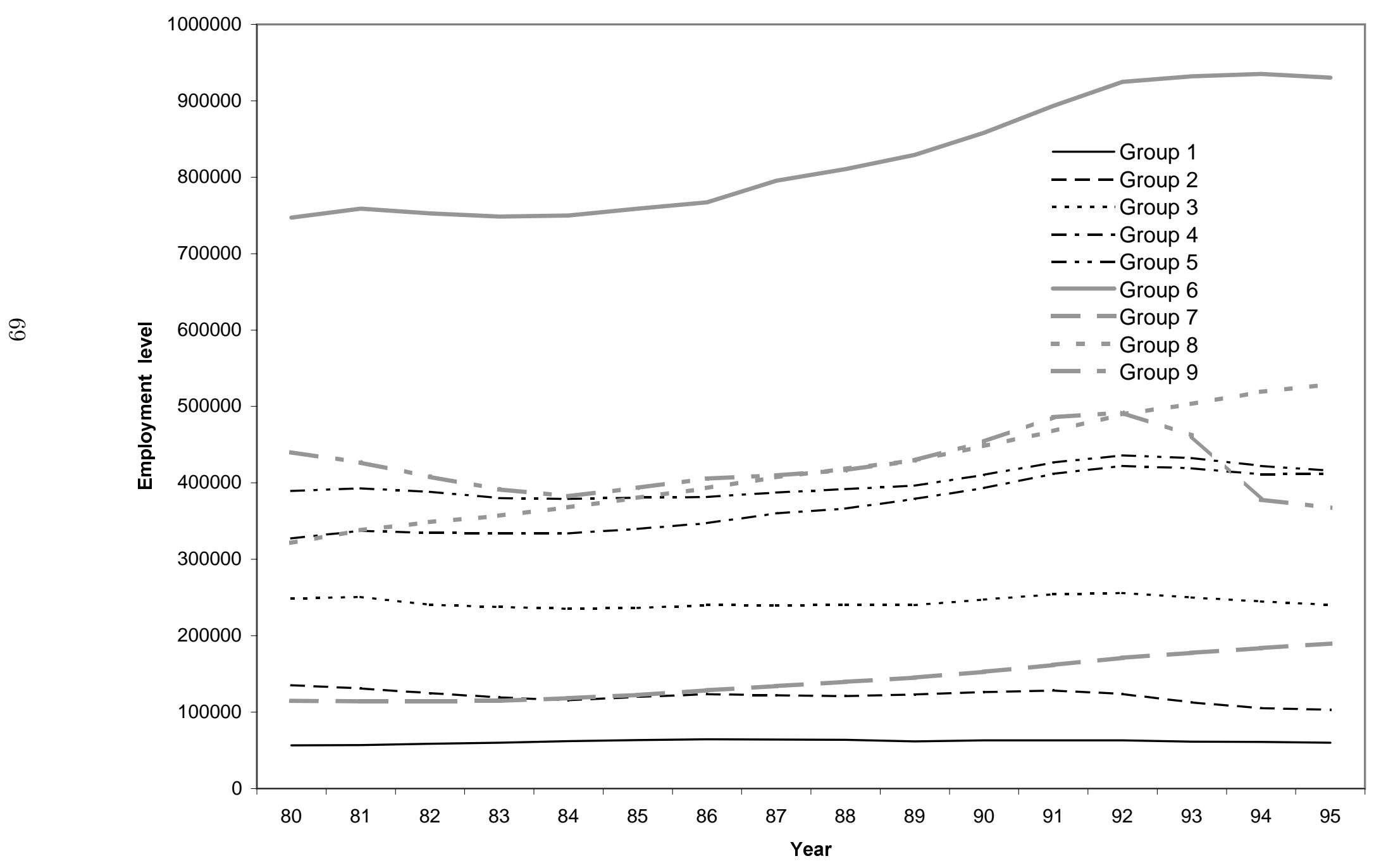


Figure A2: Relative Age Group Sizes 1980 - 1995

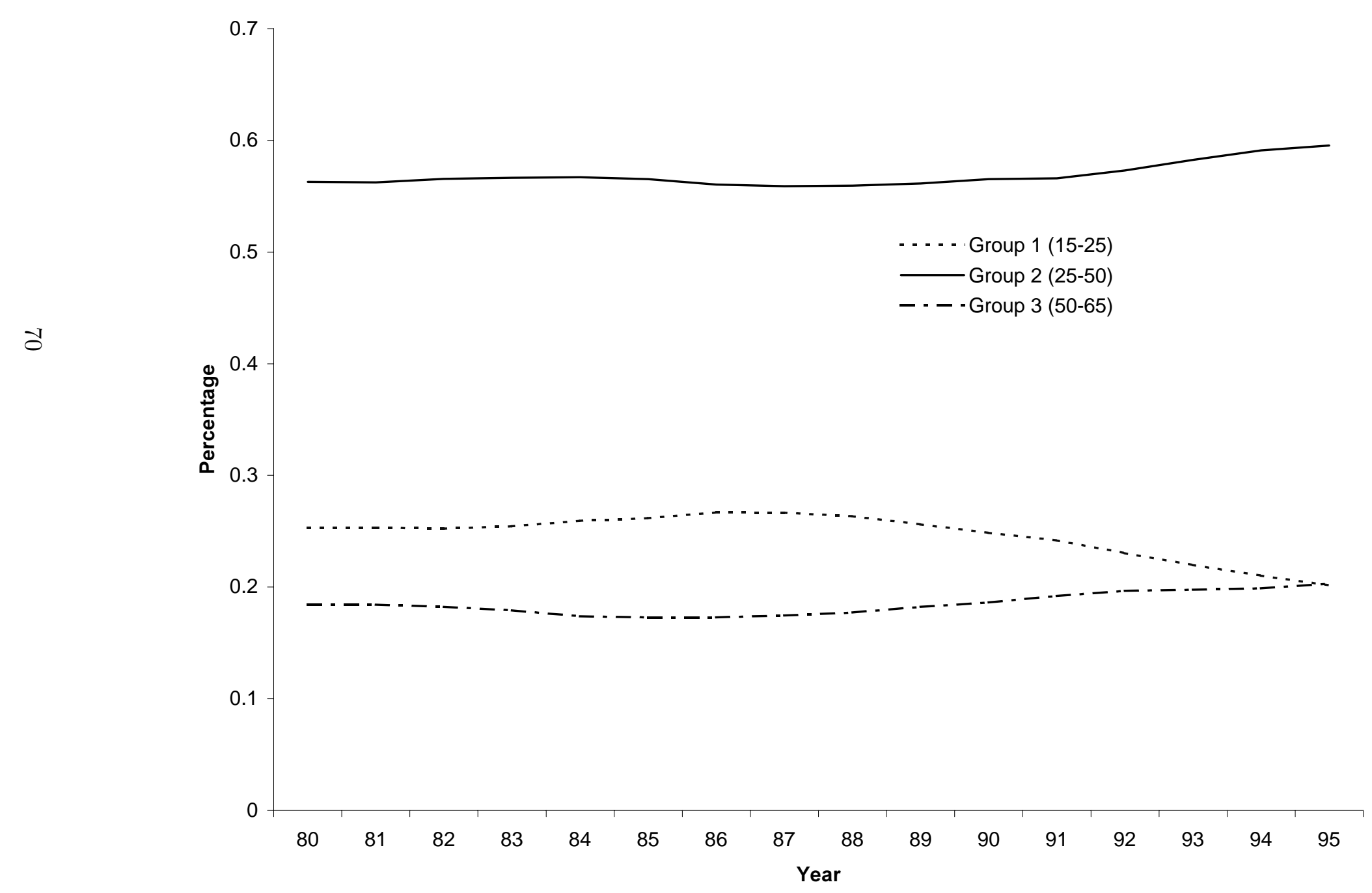


Figure A3: Relative Education Group Sizes 1980 - 1995

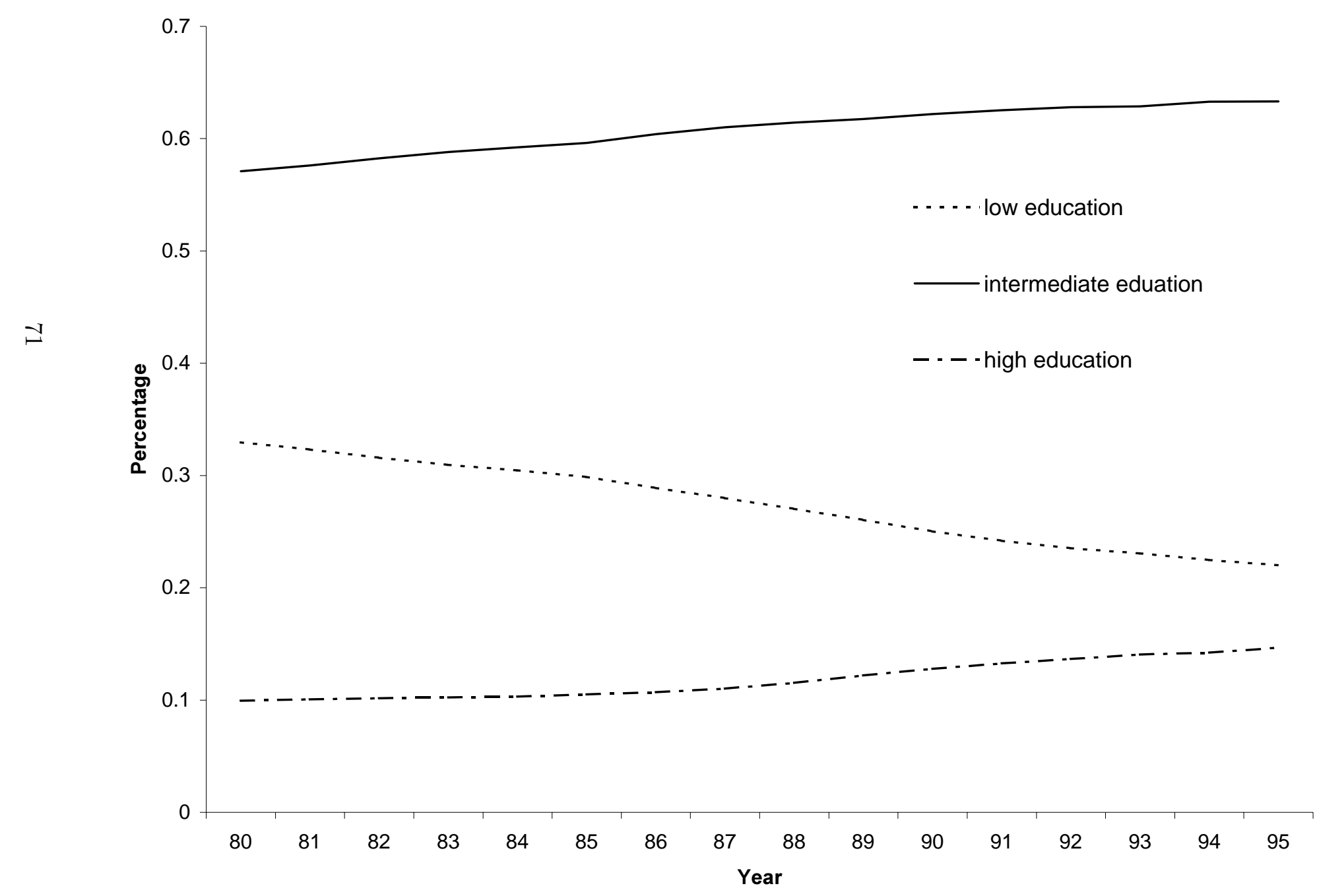




\section{IZA Discussion Papers}

No Author(s)

250

T. J. Hatton

J. G. Williamson

251 R. Yemtsov

252

R. Yemtsov

253

R. Yemtsov

254 H. Gersbach

A. Schniewind

255 H. Gersbach

A. Schniewind

256 T. Boeri

H. Brücker

257

T. Boeri

258 M. Rosholm

K. Scott

L. Husted

259 A. Ferrer-i-Carbonell

B. M.S. van Praag

260 P. Cahuc

F. Postel-Vinay

261 M. Lindahl
Titel

Area

Date

Demographic and Economic Pressure on

1

$01 / 01$

Emigration out of Africa

Labor Markets, Inequality and Poverty in Georgia 4

$01 / 01$

Inequality and Income Distribution in Georgia

4

01/01

Living Standards and Economic Vulnerability in Turkey between 1987 and 1994

4

$01 / 01$

Learning of General Equilibrium Effects and the

3

Unemployment Trap

Product Market Reforms and Unemployment in 3

Europe

Eastern Enlargement and EU-Labour Markets:

2

Perceptions, Challenges and Opportunities

Transition with Labour Supply

$02 / 01$

The Times They Are A-Changin':

Organizational Change and Immigrant

Employment Opportunities in Scandinavia

4

1

$02 / 01$

Poverty in the Russian Federation

4

02/01

Temporary Jobs, Employment Protection and

$1 / 3$

$02 / 01$

Labor Market Performance

Home versus School Learning:

5

02/01

A New Approach to Estimating the Effect of

Class Size on Achievement

Summer Learning and the Effect of Schooling:

5

$02 / 01$ 
263 N. Datta Gupta N. Smith

264 C. Dustmann

265 M. Rosholm M. Svarer

266

C. Dustmann

O. Kirchkamp

267 A. Newell

268

A. Newell

B. Reilly

269 H. Buddelmeyer

270

B. Augurzky

C. M. Schmidt

271 B. Augurzky

C. M. Schmidt

272 C. Belzil

J. Hansen

273 G. Saint-Paul

274 P. J. Pedersen

N. Smith

275 G. S. Epstein

T. Lecker

276 B. Amable

D. Gatti
Children and Career Interruptions:

5

The Family Gap in Denmark

Return Migration, Wage Differentials, and the $\quad 1$ Optimal Migration Duration

$02 / 01$

Structurally Dependent Competing Risks

1

$02 / 01$

The Optimal Migration Duration and Activity

1

$02 / 01$

Choice after Re-migration

The Distribution of Wages in Transition Countries

4

03/01

The Gender Pay Gap in the Transition from

4

Communism: Some Empirical Evidence

$03 / 01$

Re-employment Dynamics of Disabled Workers

3

$03 / 01$

The Evaluation of Community-Based

6

03/01

Interventions: A Monte Carlo Study

The Propensity Score: A Means to An End

6

03/01

Heterogeneous Returns to Human Capital and

5

03/01

Dynamic Self-Selection

Distribution and Growth in an Economy with

5

03/01

Limited Needs

Unemployment Traps: Do Financial Dis-

3

03/01

incentives Matter?

Multi-Generation Model of Immigrant Earnings: $\quad 1$

Theory and Application

$03 / 01$

The Impact of Product Market Competition on

Employment and Wages 
S. Vroman

283 M. Hagedorn

A. Kaul

V. Reinthaler Elites

Is There a Glass Ceiling in Sweden?

Welfare Analysis in a Schumpeterian Growth

First- and Second-Generation Migrants in

A. Kaul M. Kolmar Spatial Model of Restricted Labor Mobility to Internal Promotion for Young U.S. Men and Women 
C. Worswick

291 R. T. Riphahn

292

E. Wasmer

293

D. Cobb-Clark

T. F. Crossley

294

Š. Jurajda

295

F. Duffy

P. P. Walsh

296 H. S. Nielsen

M. Rosholm

N. Smith

L. Husted

297

J. C. van Ours

J. Veenman

298 P. Telhado Pereira

P. Silva Martins

299 G. Brunello

C. Lucifora

R. Winter-Ebmer

300 A. Stutzer

R. Lalive

301 J. R. Frick

G.G. Wagner

302
G. S. Epstein

A. Weiss
Cohort Effects in the Educational Attainment of

05/01 Second Generation Immigrants in Germany: An Analysis of Census Data

Between-group Competition in the Labor Market 5 and the Rising Returns to Skill: US and France 1964-2000

Gender, Comparative Advantage and Labor

1

$05 / 01$

Market Activity in Immigrant Families

Estimating the Effect of Unemployment

3

05/01

Insurance Compensation on the Labor Market

Histories of Displaced Workers

Individual Pay and Outside Options:

4

05/01

Evidence from the Polish Labour Force Survey

Intergenerational Transmissions and the School- 1

05/01 to-Work transition of $2^{\text {nd }}$ Generation Immigrants

The Educational Attainment of Second Generation 1 Immigrants in The Netherlands

05/01

Returns to Education and Wage Equations

5

$06 / 01$

The Wage Expectations of European College

5

06/01

Students

The Role of Social Work Norms in Job Searching 5 and Subjective Well-Being

06/01

Economic and Social Perspectives of Immigrant 1 Children in Germany

06/01

A Theory of Immigration Amnesties

1

06/01 

H. Bonin
G. Abío
E. Berenguer
J. Gil
C. Patxot

\section{Labour Market Trends in Spain}

Downsizing

06/01

Two-Sided Learning, Labor Turnover and Worker 1 Displacement

On the Complementarity between Education and

Chronic Diseases: An Alternative Model for Monetary Appraisal 
315 W. H. J. Hassink R. Schettkat

316 M. Frondel

C. M. Schmidt

317 R. Winkelmann

318 M. Pannenberg

G. G. Wagner

319 R. Euwals

R. Winkelmann

320 R. Fahr

U. Sunde

321

P. Telhado Pereira

P. Silva Martins

322

O. Hübler

U. Jirjahn

323 A. Frederiksen

E. K. Graversen

N. Smith

324 M. Pflüger

325 R. A. Hart

J. R. Malley

U. Woitek

326 J. S. Earle

Á. Telegdy

327

H. Gersbach

A. Schmutzler
On Price-Setting for Identical Products in Markets

Rejecting Capital-Skill Complementarity at all

Costs

Health Care Reform and the Number of Doctor

Overtime Work, Overtime Compensation and the 1

06/01

Distribution of Economic Well-Being: Evidence for West Germany and Great Britain

Why do Firms Train? Empirical Evidence on the

06/01

First Labour Market Outcomes of Graduated

1

Apprentices

Strategic Hiring Behavior in Empirical Matching 1

Functions

06/01

Is there a Return - Risk Link in Education?

5

07/01

Works Councils and Collective Bargaining in

1

$07 / 01$

Germany: The Impact on Productivity and Wages

Overtime Work, Dual Job Holding and Taxation

1

07/01

Trade, Technology and Labour Markets: Empirical

2

Controversies in the Light of the Jones Model

07/01

Real Wages and the Cycle: The View from the

1

07/01

Frequency Domain

Privatization and Productivity in Romanian

4

$07 / 01$

Industry: Evidence from a Comprehensive

Enterprise Panel

A Product Market Theory of Training and Turnover 5 in Firms 
333 W. Arulampalam

R. A. Naylor

J. P. Smith

334

P. A. Puhani

335
R. Fahr

U. Sunde
A Hazard Model of the Probability of Medical

5 School Dropout in the United Kingdom

Wage Rigidities in Western Germany? Microeconometric Evidence from the 1990s

1

$07 / 01$

Disaggregate Matching Functions

$07 / 01$

An updated list of IZA Discussion Papers is available on the center's homepage www.iza.org. 